\title{
RETRIEVING HISTORIES: A CASE STUDY OF CYRIL J. BROWN'S FAMILY ALBUM
}

by

Aliya Mazari, Honours Bachelor of Arts, University of Toronto, Toronto 2011

\author{
A thesis \\ presented to Ryerson University \\ in partial fulfillment of the \\ requirements for the degree of \\ Master of Arts \\ in the Program of
}

Film and Photography Preservation and Collections Management

Toronto, Ontario, Canada, 2015

(C)Aliya Mazari 2016 


\section{AUTHOR'S DECLARATION FOR ELECTRONIC SUBMISSION OF A THESIS}

I hereby declare that I am the sole author of this thesis. This is a true copy of the thesis, including any required final revisions.

I authorize Ryerson University to lend this this to other institutions or individuals for the purpose of scholarly research.

I further authorize Ryerson University to reproduce this this by photocopying or by other means, in total or in part, at the request of other institutions or individuals for the purpose of scholarly research.

Aliya Mazari

I understand that my thesis may be made electronically available to the public. 


\begin{abstract}
$\underline{\text { Abstract }}$
Retrieving Histories: A Case Study of Cyril J. Brown's Family Album

Aliya Mazari

Thesis (M.A) Fall 2016 -Film and Photographic Preservation and Collections Management Ryerson University

This thesis examines the visual construction of family in the previously unknown personal album of Cyril J. Brown in the Royal Ontario Museum's South Asian photography collection. Beginning with retrieving the object's personal history and tracing its links to the Young Men's Christian Association (YMCA), the crossover in photographic content between Brown's personal album and the Kautz Family YMCA Archive at the University of Minnesota is examined. In doing so, I argue that family photography and institutional forms of image making are interconnected through the use of familial photographic tropes and pictorialist techniques which are common to both collections. Finally, concluding with a reflection on the significance of Brown's album for the genre of family photography.
\end{abstract}




\section{Acknowledgements}

This thesis could not have been completed without the help of many people. First and foremost, I would like to thank my advisors. Dr. Deepali Dewan for giving me the opportunity to not only intern at the Royal Ontario Museum (ROM) but introduced me to the album that set off this entire journey, and in doing so expanded my ways of seeing, and for that I am eternally grateful. Dr. Thy Phu, your guidance and support throughout this process has been invaluable, especially at times when I wasn't sure where this project was headed. Your belief in the project and your encouragement were indispensable.

Research could not have been done without with the help of Dr. Catherine Asher, Emily Rohan, Ryan Bean and the staff at the University of Minnesota and the staff at the ROM. Special thank you to the faculty, staff and my fellow students at Ryerson University, especially Marta Braun for facilitating support for additional research to be carried out at the Kautz Family YMCA Archives.

My family and friends played a vital role during this entire process, thank you for putting up with the constant discussion of CJB. In particular, Shirin and Tomas for your irreplaceable advice and artistic inspiration. Wali and Zeenat, ye aap kay liye hai. 
1. Author's Declaration .............................................................................................. ii

2. Abstract …..................................................................................................... iii

3. Acknowledgements …................................................................................................... iv

4. List of Figures ............................................................................................................. vi

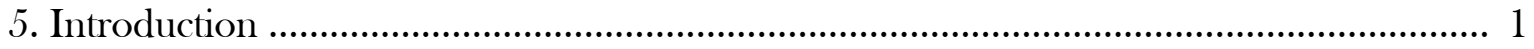

6. Chapter 1: The YMCA Family .................................................................................. 19

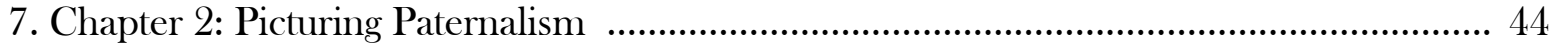

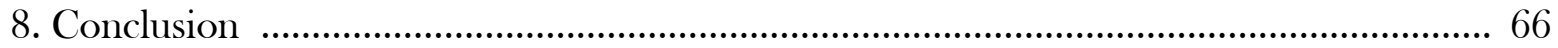

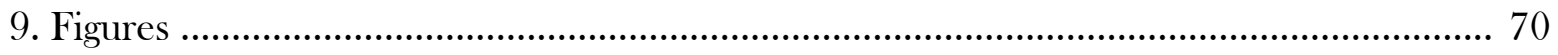

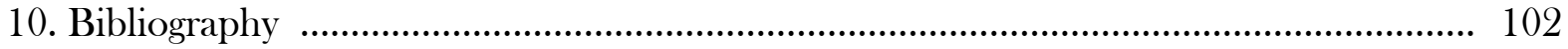




\section{$\underline{\text { List of Figures }}$}

1. Leather-bound photograph album, circa 1910-1920, Royal Ontario Museum collection.

2. Unknown photographer, 1911, silver gelatin print mounted on loose album page associated with Cyril J. Brown's album, Royal Ontario Museum collection.

3. Unknown photographer, circa 1910s, silver gelatin print mounted in album of Cyril J. Brown, Royal Ontario Museum collection.

4. W. Archer, circa 1910-1913, enlargement from photographic negative mounted on page in album dedicated to Mrs. Jessop. India scrapbook collection. India Files (Y.USA.9-2-40). Kautz Family YMCA Archives. University of Minnesota.

5. Digital reproduction from Susan Billington-Harper, In the Shadow of the Mahatma: Bishop V.S Azariah and the Travials of Christianity in British India. Page 220.

6. Digital reproduction from Susan Billington-Harper, In the Shadow of the Mahatma: Bishop V.S Azariah and the Travails of Christianity in British India, page 200.

7. Digital reproduction from Susan Billington-Harper, In the Shadow of the Mahatma: Bishop V.S Azariah and the Travails of Christianity in British India, page 220.

8. Digital reproduction from Ian Tyrrell, Reforming the World: The Creation of America's Moral Empire, page 83.

9. Unknown photographer, circa 1910s, silver gelatin prints mounted on loose page associated with album of Cyril J. Brown, Royal Ontario Museum collection.

10. Cyril J. Brown's entry in William Mort Jessop's autograph book. William Mort and Louise Ahl Jessop folder. Box 101. Biographical files (Y.USA12). Kautz Family YMCA Archives, University of Minnesota.

11. Unknown photographer, circa 1910s, silver gelatin prints mounted in album of Cyril J. Brown, Royal Ontario Museum collection.

12. W. Archer, circa 1910-1913, enlargement from photographic negative mounted on page in album dedicated to Mrs. Jessop. India scrapbook collection. India Files (Y.USA.9-2-40). Kautz Family YMCA Archives. University of Minnesota. 
13. Unknown photographer, circa 1910s, silver gelatin print mounted on loose page associated with album of Cyril J. Brown, Royal Ontario Museum collection.

14. Unknown photographer, circa 1910s, silver gelatin print mounted on loose page associated with album of Cyril J. Brown, Royal Ontario Museum collection.

15. Unknown photographer, circa 1910s, silver gelatin prints mounted on loose page associated with album of Cyril J. Brown, Royal Ontario Museum collection.

16. Unknown photographer,1910, silver gelatin print mounted on loose page associated with album of Cyril J. Brown, Royal Ontario Museum collection.

17. Unknown photographer, circa 1910s, silver gelatin print mounted on loose page associated with album of Cyril J. Brown, Royal Ontario Museum collection.

18. Unknown photographer, 1913, silver gelatin print mounted on in album of Cyril J. Brown, Royal Ontario Museum collection.

19. J.N Farquhar's entry in William Mort Jessop's autograph book. William Mort and Louise Ahl Jessop folder. Box 101. Biographical files (Y.USA12). Kautz Family YMCA Archives, University of Minnesota.

20. Percy Brown's entry in William Mort Jessop's autograph book. William Mort and Louise Ahl Jessop folder. Box 101. Biographical Files (Y.USA 12). Kautz Family YMCA Archives, University of Minnesota.

21. Unknown photographer, circa 1910s, silver gelatin print mounted on in album of Cyril J. Brown, Royal Ontario Museum collection.

22. W. Archer, circa 1910-1913, enlargement from photographic negative mounted on page in album dedicated to Mrs. Jessop India scrapbook collection. India Files (Y.USA.9-2-40). Kautz Family YMCA Archives. University of Minnesota.

23. Unknown photographer, circa 1910s, silver gelatin print mounted on in album of Cyril J. Brown, Royal Ontario Museum collection.

24. W. Archer, circa 1910-1913, enlargement from photographic negative mounted on page in album dedicated to Mrs. Jessop India scrapbook collection. India Files (Y.USA.9-2-40). Kautz Family YMCA Archives. University of Minnesota.

25. Digital reproduction from The Coming of Photography to India, page 119. 
26. W. Archer, circa 1910-1913, inside of back cover and first page of album dedicated to Mrs. Jessop. India scrapbook collection. India Files (Y.USA.9-2-40). Kautz Family YMCA Archives. University of Minnesota.

27. Digital reproduction of India Awakening, pages 152-153.

28. Unknown photographer, circa 1910s, silver gelatin print mounted on loose page associated with album of Cyril J. Brown, Royal Ontario Museum collection.

29. Unknown photographer, circa 1910s, silver gelatin print mounted on loose page associated with album of Cyril J. Brown, Royal Ontario Museum collection.

30. Unknown photographer, circa 1910s, silver gelatin print mounted on loose page associated with album of Cyril J. Brown, Royal Ontario Museum collection.

31. Unknown photographer, circa 1910s, silver gelatin print mounted on loose page associated with album of Cyril J. Brown, Royal Ontario Museum collection.

32. Unknown photographer, circa 1910s, silver gelatin print mounted on loose page associated with album of Cyril J. Brown, Royal Ontario Museum collection.

33. Unknown photographer, circa 1910s, silver gelatin print mounted on loose page associated with album of Cyril J. Brown, Royal Ontario Museum collection. 


\section{$\underline{\text { Introduction }}$}

Many museum collections contain "orphaned" photos, or family albums that have been separated from their family history. Without this history, family albums can easily become decontextualized and aestheticized. To address this challenge, during my summer internship at the Royal Ontario Museum, I was tasked with identifying the owner of an orphaned family album in the South Asian photography collection; with, that is, reconstituting as much as possible the history of this artifact. Little was known about the object's provenance, aside from being donated as part of a larger donation by influential architect Cyrus Jhabvala in 2007. Jhabvala most likely purchased the album from a photography dealer and may have been inclined towards the object because of the many architectural shots it contains. But it wasn't the architectural elements that fascinated me. Instead, I was concerned with the placement of these elements within the domestic context of the family album, which raised such pivotal questions as: How does one interpret orphan albums? What methods might there be to understand their meanings when the contexts of their production and circulation have been lost?

The object that interested me most was a full green leather-bound album, measuring $9.8 \mathrm{x}$ 11.6 inches, with 2-4 photographs attached to each page (Fig.1). Fourteen loose album pages are also associated with this set. Together the set contains 195 gelatin silver prints, which are roughly the same size (4 x 6 inches). Most photographs tend to be landscape and architectural views from around India, from Rajasthan, Delhi, and Himachal Pradesh. Some photographs featured posed portraits of school children poetically captioned “The Three Graces," reflecting an early $20^{\text {th }}$ century interest in pictorialist photography, which I discuss in Chapter two. Each image has been carefully arranged on the page with one or two descriptive lines captioned in black ink. Several of the images in the album are group portraits, depicting popular leisure activities like tiffin picnics, visits to dak bungalows, and swimming at the seashore. The captions also indicated when some of 
the photos were taken, indicating that the album ranges in date from 1910 to 1920 . These photographs were not just domestic images; they were also situated within a specific institution: the Young Man's Christian Association (YMCA). The intersection between institutional forms of image making and the family can be seen in the work of Marianne Hirsch's Familial Frames: Photography, Narrative and Postmemory particularly through her conception of the "familial gaze" and her discussion of the human family. ${ }^{1}$ This thesis builds on Hirsch's insight, suggesting that, to understand the meanings of these photos we need to interrogate the relationship between two discursive sites, namely the family and the YMCA.

A first step to interpreting these orphan albums is to identify its original owner. There were a few photos that stood out as useful clues in this task. In particular, one man appeared in various photos, which were captioned “C.J.B.” below the image. Even when he appeared in group photos that named his companions, this person was referred to by his initials only. This shorthand means of identification suggests an intimate connection between the man and the album. In several photos of this same man, we can see the caption "hum” written in cursive below the image. This caught my attention because "hum" is the Hindi first-person plural, which roughly translates as "we." In this context, "hum” is an honorific way of saying "me." The use of this word signaled and identified CBJ as the person who put together the album. Moreover, he was likely the main audience for the album, as there would have been no need for him to write out his initials, or indeed to write his name at all; "me" was enough. The next big identifying clue was in the smallest detail of a photo captioned Residents Y.M.C.A. Calcutta Jan 1911 (Fig.2). The image, which is reminiscent of an official class portrait of the period, was organized with the most important people

\footnotetext{
${ }^{1}$ Marianne Hirsch.Familial Frames: Photography, Narrative and Postmemory. Cambridge: Harvard University Press, 1997
} 
seated in the center, with "C.J.B." standing towards the center of the back row. Its format indicated that it was likely taken to mark an important occasion.

After discovering that the YMCA India archives was located at the University of Minnesota library, I worked with Minneapolis-based researcher, Emily Rohan, who uncovered a copy of the same photo there. And yet, unlike the ROM's photo, the YMCA archive photo was not pasted into an album, and thus we could read the writing on the back, which identified the couple seated in the middle of the image as two influential YMCA officials, Mr. and Mrs. William Jessop. Emily then discovered an autograph book once owned by Mr. Jessop. In that book, there was one signature that matched the mysterious initials of the mystery owner of the album. I was thus able to learn that “C.J.B” was “Cyril J. Brown.”

Cyril J. Brown's name appears in the list of Committee of Management members for the Central and Wellington branches of the YMCA of Calcutta annual report for the following years: $1915-1919,{ }^{2}$ (1920 report is missing), 1921, 1924, 1925, and 1926 (1927 report is missing). ${ }^{3}$ He is absent from the 1920, 1922, and 1923 annual reports, and presumably not on the Management of Committee in those years. After 1926, Brown is no longer named in the list, and oddly there is no mention of his departure in the report itself. (This report usually mentions departures of members and thanks them for years of service).

Although I had been able to identify an owner with Emily's help, a number of questions remained: Given that Brown's photograph is also in the YMCA archives, to what extent does family photography intersect with the YMCA's visual culture? What is the significance of this intersection, as it relates to the construction of white Christian masculinity in the Indian context? These are the key questions that I explore in this thesis.

\footnotetext{
${ }^{2} \mathrm{He}$ is honorary treasurer for the Committee of Management.

${ }^{3}$ Calcutta Annual reports, 1859-1931. Box 2. India Files Y.USA.9-2-40. Kautz Family YMCA Archives. University of Minnesota.
} 
To explore these questions, I undertook primary research at the Kautz Family YMCA archives, which is located at the University of Minnesota- Twin Cities campus. The Kautz Family YMCA Archives houses all of the American YMCA files, including the institution's photographs, postcards, and scrapbook collection (over 200 linear feet) and India files (1854-1995). Although, YMCAs in India operated independently, they relied on financial and administrative support from the International Committee, which was largely funded by the YMCA based in the United States. As a member of the Calcutta ${ }^{4}$ YMCA's management committee, however, Brown would not have been officially employed by the YMCA, which makes it all the more curious (and, for me, fortuitous) that his photographs should be included within this archive.

To determine the extent to which Brown's album overlaps with the YMCA's visual culture, I turned to the biographical file collection that houses Mr. and Mrs. Jessop's personal papers, pamphlets, newspaper clippings and journals (including the autograph book). The archival records trace their overseas careers, most notably in India (1910-1913) and Egypt (1913-1921). Alongside their professional YMCA duties, the Jessops were avid photographers. In fact, Mrs. Jessop was a member of the National Geographic Society and her article titled "A Pilgrimage to Amernath, Himalayan Shrine of the Hindu Faith” was published in the November 1921 issue of National Geographic Magazine. By 1908, more than half of the National Geographic Magazine consisted of photographs. ${ }^{5}$ Therefore, most of Mrs. Jessop's article is illustrated with a total of twenty-nine photographs. Most of these photographs are credited to her husband while the remainder is credited to YMCA secretary E.M Moffat, and YMCA Calcutta Committee of Management

\footnotetext{
${ }^{4}$ Calcutta was renamed Kolkata in 2001. To keep in line with the historicity of this study, hereinafter Kolkata will be referred to as Calcutta.

${ }^{5}$ Philip J. Pauly. "The World and All That is in It: The National Geographic Society, 1888-1918" in American Quarterly 31:4 (1979) pages 517-532.
} 
member, A. Hodgson. In this way, the visual culture of the YMCA intersects with the genre of family photography and with that of popular illustrated magazines.

I began to glimpse that family photography does not simply appear within the domestic domain. In fact, imagery similar to that found in Mrs. Jessop's collection can also be seen in Brown's album, particularly picturesque landscape shots and ethnographic portraits of Indian women (whose significance I discuss in detail in Chapter two). In other words, some of the images included in Brown's album not only were also preserved in the YMCA archive, but were also related to images that were reproduced and circulated as part of National Geographic. These multiple contexts, which underscore the broader frameworks for viewing domestic images, suggest that we need to expand our definition of family photography.

Just as importantly, I discovered that the photographs credited to “A. Hodgson” in Mrs. Jessop's article were also found in the YMCA Scrapbook collection. (The scrapbook, however, is not archived with the Jessop files in the biographical records.) This scrapbook was made by YMCA Committee of Management member W. Archer and is dedicated to Mrs. Jessop, as indicated by the caption seen on the back cover:

\author{
An Indian Souvenir. \\ To Mrs. Jessop. \\ With kind regards \& wishes. \\ W. Archer. \\ Calcutta. \\ Sept.1913
}

The album measures $9 \times 12.5$ inches and contains twenty-two gelatin silver prints that are mounted on different coloured cardboard sheets. Each sheet is hole-punched on the left and held together by a thick cord. Each print is carefully centered and a descriptive caption is hand-written below. The majority of these photographs depicts stylized Indian women and children; they also include landscape and architectural shots from Delhi, Calcutta, and Agra. There is only one photograph 
that does not feature Indian people as the primary subjects; this photograph instead records the visit of King George V and Queen Mary to Calcutta. ${ }^{6}$ There are also five loose silver gelatin photographs associated with this scrapbook, two of which appear in Mrs. Jessop's National Geographic article. My study of Brown's album, alongside W. Archer's album will serve as a case study in unpacking the meanings of family photographs when they exist in multiple formats-- a personal album and the YMCA institutional archive-- and intersect with one another.

For example, Brown and Archer's album both contain an image taken at the procession of Lord Jagannātha at Puri. ${ }^{7}$ Brown's photograph (Fig.3) measures $41 / 2 \times 61 / 2$ inches and is captioned Puri The Juggernaut Car ready for procession. Archer's album contains a photograph captioned Car of "Jagannath" at the Car Festival PuriJuly 1913 and measures $77 / 8$ x 6 1/2 inches (Fig. 4). Both images are almost identical in composition: they employ a camera angle that is taken at a distance in order to depict both the procession cart and the large crowd audience. The size of Archer's image suggests that it was not taken on standard roll film. ${ }^{8}$ Rather, it most likely was enlarged and cropped from a negative. 'In fact, Archer's photograph starts about one fourth of the way in from the right side of Brown's image. Brown's caption uses the term "juggernaut" to describe the procession car; this spelling is important because it exemplifies many scholars describe as "hobson-jobsonized,"10 the process in which Indian words are adapted to British

\footnotetext{
${ }^{6}$ This was part of a larger tour of India which began with the imperial durbar of 1911 which commemorated the coronation of King George V and Queen Mary in England and announced the change of India's capital from Calcutta to Delhi.

${ }^{7}$ Gavin Flood. An Introduction to Hinduism. Cambridge: Cambridge University Press, 1996. Page 14

${ }^{8}$ With 4 1/4 x 6 1/2 inches being a "de facto standard," for more see Todd Gustavson Camera: A History of Photography from Daguerreotype to Digital. New York: Sterling Innovation, 2009. Page 157.

${ }^{9}$ Mark Osterman. "The Technical Evolution of Photography in the $19^{\text {th }}$ century" in Focal Encyclopedia of Photography: Digital Imaging, Theory and Applications, History and Science. Edited by Michael R. Peres. Amsterdam and Boston: Elsevier/ Focal Press, 2007. Page 73.

${ }^{10}$ For more see Nirad C. Chaudhuri "A Historical Perspective" in Yule and Burnell, Hobson Jobson. Sittingbourne, UK: Linguasia, 1994, xi Also see Traci Nagle "The Visible and Invisible Influence of Yule's Hobson-Jobson on Murray's Oxford English Dictionary” in International Journal of Lexicography 27:3 (2014) pages 280-308.
} 
phonetics and cultural associations that may result in the change or loss of nuances found in the original Indian vernacular languages. The British conception of "juggernaut" is based on the Sanskrit Jagannāth "meaning 'lord of the universe', a reference to the Hindu deity Vishnu." "This term was understood both as an event where people are blindly devoted and a big, bulky vehicle, with both of these narratives drawing on witnessing the annual festival in Puri. ${ }^{12}$ The caption "Juggernaut" in photographs of the Puri temple complex appeared in popular missionary publications like the Missionary Papers, ${ }^{13}$ which circulated both inside and outside missionary circles. ${ }^{14}$ Brown's use of this term accordingly references a familiar Christian trope of the unitary conception of Hinduism. ${ }^{15}$ Yet, Brown's caption suggests that Brown and Archer chose to take these images before the start of the procession. For American missionaries, images of idolatry represented the blind faith of the ignorant nonbeliever or child, ${ }^{16}$ and the "fight against idolatry" ${ }^{17}$ was a popular rallying trope for overseas missionary work. ${ }^{18}$ If this image was taken during the procession it would emphasize the visual devotion of idolatry. Archer's use of quotations in the

\footnotetext{
${ }^{11}$ Susan Purcell. "The Law of Hobson-Jobson" in English Today 25:1 (March 2009). Page 61.

${ }^{12}$ Susan Purcell. "The Law of Hobson-Jobson” in English Today 25:1 (March 2009). Page 61 Also see Traci Nagle

“The Visible and Invisible Influence of Yule's Hobson-Jobson on Murray's Oxford English Dictionary" in International Journal of Lexicography 27:3 (August 2014) pages 280-308 For the inconsistencies within HobsonJobson see Ari Singh Anand. "Cosmopolitanism in Hobson-Jobson: Remaking Imperial Subjects” in Comparative Studies of South Asia, Africa and the Middle East 31:2 (2011) Pages 521-537.

${ }^{13}$ Brown's father was a Reverend working with the Church Missionary Society (CMS). The CMS published the Missionary Papers which were available to anyone that donated a penny a week or more. For more see Brian K. Pennington. Was Hinduism Invented: Britons, Indians, and the Colonial Construction of Religion. New York: Oxford University Press, 2005. Pages 49-58.

${ }^{14}$ Brian K. Pennington. Was Hinduism Invented: Britons, Indians, and the Colonial Construction of Religion. New York: Oxford University Press, 2005. Pages 60-100, especially 84-98.

${ }^{15}$ Ibid, page 100. For more on juggernaut see Subhakanta Behera."Essentialising the Jagannath cult: a discourse on self and other" in Journal of Comparative Literature \& Aesthetics 30:1-2 ( Annual 2007) pages 51-93.

${ }^{16}$ David Morgan. The Sacred Gaze: Religious Visual Culture in Theory and Practice. Berkeley: University of California Press, 2005. Page 120-125.

${ }^{17}$ Ibid.

${ }^{18}$ For more see Dominic Janes. Victorian Reformation: The Fight Over Idolatry in the Church of England, $1840-1860$. Oxford: Oxford University Press, 2009. Especially pages 105-108. Also see Kenneth Ingham. "The English Evangelicals and the Pilgrim Tax" in The Journal of the Royal Asiatic Society 85:1-2 (1953) pages 13-22.
} 
caption "Jagannath" similarly draws on the prevailing Christian stereotypes associated with Hindu temples. ${ }^{19}$

Although Brown and Archer placed their images in their personal albums and in a souvenir album intended for Mrs. Jessop, their institutional connection to the YMCA remains. The YMCA became interested in establishing a Protestant ashram ${ }^{20}$ in $1912 .{ }^{21}$ Eventually, the YMCA established a Christian mandir (temple) of its own in Puri, ${ }^{22}$ as part of a larger practice of “indigenization." ${ }^{23}$ Given the importance of the YMCA's focus on adapting its ethos in India, it is imperative not only to consider Archer and Brown's album together but also to contextualize both artifacts within the larger history and visual culture of the YMCA archive. In doing so, my goal is to understand how the YMCA's institutional policies, particularly its employment of familial discourses, inform Brown's personal photography and Archer's album-both of which are, in turn, represented in the YMCA archive.

By contextualizing Brown's album against the larger YMCA visual culture, I will demonstrate not only the fluidity of family photographs but also their connection with extra-familial institutions like the YMCA. Because these albums were constructed and intended for viewers in Europe and the United States, I will address the ways that meanings were framed for this broader,

\footnotetext{
${ }^{19}$ For more see Richard H. Davis. Lives of Indian Images. Princeton: Princeton University Press, 1997. Pages 204207. Jennifer C. Snow. Protestant Missionaries, Asian Immigrants, and Ideologies of Race in America, 1850-1924. New York: Routledge, 2007. Also see Deirdre M. Moloney. National Insecurities: Immigrants and U.S. Deportation Policy Since 1882. Chapel Hill: University of North Carolina, 2012. Page 148.

${ }^{20}$ The Christian Ashram movement began as early as with the practice of Roberto de Noblili in the late sixteenth century, the differences in Christian conceptions of the ashram see Helen Ralston. Christian Ashrams: A New Religious Movement in Contemporary India. Lewiston NY and Queesnston, ON: Edwin Mellon Press, 1987. Also see the work of Paul M. Collins. Christian Inculturation in India. Aldershot, England: Ashgate, 2007.

${ }^{21}$ Mario 1. Aguilar. Christian Ashrams, Hindu Caves and Sacred Rivers: Christian-Hindu Monastic Dialogue in India 1950-1993. London: Jessica Kingsley Publishers, 2016. Page 35.

${ }^{22}$ Photographs of Puri temples, the Christian mandir and Rev Sircar can be seen in the pamphlet "God in a Garden" dated 1931, however, the dates of the images are unknown. India Photograph folder 14, Photograph flat file collection, Kautz Family YMCA Archives.

${ }^{23}$ M.D David. The YMCA and the Making of Modern India: A Centenary History. New Delhi: Association Press, 1992. Pages 97-133. Also see Kenneth Latourrette. World Service: A History of the Foreign Work and World Service of the Young Men's Christian Association of the United States and Canada. New York Association Press, 121-127.
} 
impersonal audience. A particular challenge of this study is that, aside from minor biographical details, little is known about Brown and his YMCA community. Nevertheless, Brown and Archer's albums present a community, a family connected together by faith, but also bound by race, class and culture-and differentiated from the exotic others, the Indian subjects, who also appear in these photographs. My thesis thus focuses on the construction of ideal white Christian masculinity through the intersecting familial discourses of YMCA visual culture and Brown and Archer's personal albums. ${ }^{24}$

My study begins with a review of the literature that offers approaches to interpreting family photography. To understand the YMCA context, I also include a consideration of the YMCA's visual culture and an overview of the YMCA's history in India, with specific emphasis on the relationship between the YMCA's universal fraternal bonds and its implication in India. This review enables me to situate my critical perspective on Brown's album with the YMCA's institutional history and in relationship to scholarship on visual culture.

Elizabeth Edwards and Janice Hart's (eds) Photographs Object Histories: On the Materiality of Imagesdefines photographs as a "three-dimensional thing, not only a twodimensional image...photographs are both images and physical objects that exist in time and space and thus in social and cultural experience. ${ }^{25}$ This focus on materiality is particularly relevant for family albums, where a physical interaction is part of the album's function. Albums are meant to be held, opened, caressed, glued in, added to, and more often than not, crossed over, erased, and removed from any personal records. For example, the images, the captions, the layout and sequencing inform the way the album is used and understood. The material approach developed

\footnotetext{
${ }^{24}$ Although the Indian men and women that are the subjects of many of the photographs may have viewed these images differently, their perspective is beyond the scope of this study.

${ }^{25}$ Elizabeth Edwards and Janice Hart (eds). Photographs Object Histories: On the Materiality of Things. London and New York: Routledge, 2004, page 1.
} 
by Edwards and Hart offers a useful starting point for analyzing Brown's album. Foregrounding the materiality of Cyril Brown's album enables us to grasp that it is not simply an object in the Royal Ontario Museum's collection; rather, we must account for its meanings as produced through a larger process of use, circulation, and consumption.

This thesis takes up the challenge of tracing this larger process. Tina Campt's Image Matters: Archive, Photography, and the African Diaspora in Europe ${ }^{26}$ builds on Edwards's emphasis on materiality to grapple with the ways in which family photographs matter. Extending Edwards's insights, Campt insists that we approach these artifacts through their "sensory, affective and archival dynamics." ${ }^{27}$ Whereas Edwards underscores the importance of context, Campt's analysis takes up the problem posed when objects lack context, when they have lost their personal histories. This is particularly relevant for Brown's album: to what extent does the personal history of the object determine its meaning? Reading images as "complex aesthetic texts and affective objects...regardless of the extent to which we can authenticate their origins, uses, patterns of circulation, modes and sites of production, or biographical contexts, ${ }^{28}$ Campt's conception of the "social life of the photo" broadens meaning beyond the sitter's and photographer's intention and decision to take particular kinds of photos. ${ }^{29}$ Contextualizing Brown's album against the larger visual culture of the YMCA reveals particular types of image-making practices. Chapter one accordingly considers what these particular images tell us about Brown and his photographic network in relation to the YMCA fraternal family.

Within the YMCA framework, the men portrayed in the photos would be considered as

\footnotetext{
${ }^{26}$ Tina Campt. Image Matters: Archive, Photography, and the African Diaspora in Europe. Durham and London: Duke University Press, 2012.

${ }^{27}$ Ibid, page 20.

${ }^{28}$ Ibid, page 86.

${ }^{29}$ Ibid, page 6 .
} 
part of a Christian fraternal family, a Christian brotherhood. Therefore, it is essential to expand the notion of family beyond kin. Here, Marianne Hirsch's conception of the family offers a helpful definition. For Hirsch, family denotes more than biological ties; the term encompasses an "affiliative group, and the affiliations that create it are constructed through various relational, cultural, and institutional processes...A familial look is thus an engagement in a particular form of relationship, mutually constitutive, mediated by the familial gaze but exceeding it through its subject contingency. ${ }^{3^{0} 0}$ The familial gaze does not reside wholly in a statically defined private sphere, but rather intersects with other institutions and ideological frameworks. In a similar spirit, Laura Wexler's Tender Violence: Domestic Visions in an Age of U.S. Imperialism ${ }^{3 l}$ asserts that "domestic images" can function in the same way imperialist photographs can from the public sphere. ${ }^{32}$ Therefore, domestic images "may be- but need not be- representations of and for a socalled separate sphere of family life." ${ }^{33}$

Simon Watney's “On the Institutions of Photography” in Photography/ Politics Two likewise argues that institutions and the ideologies which inform the institutions are intertwined. ${ }^{34}$ This does not mean that an institution's use of an image defines its meaning; rather it is "photographic rhetoric- repetition, analogy, irony, and so on - which inflects meaning right across the genres and institutions of photo-practices. ${ }^{{ }^{35}}$ This is particularly useful when considering images which are both in Brown's personal album and in the YMCA archive.

\footnotetext{
${ }^{30}$ Hirsch, Marianne. Family Frames: Photography, Narrative and Postmemory. Cambridge: Harvard University Press, 1997.Pages 10-11.

${ }^{31}$ Laura Wexler. Tender Violence: Domestic Visions in an Age of U.S. Imperialism. Chapel Hill and London: University of North Carolina Press, 200.

${ }^{32}$ Ibid, page 21.

${ }^{33}$ Ibid.

${ }^{34}$ Simon Watney. "On the Institutions of Photography” in Photography/ Politics Two. London: Photography Workshop, 1979. Pages 187-197,

${ }^{35}$ Ibid, page 191.
} 
The YMCA: Race, Class, and Visual Culture

The YMCA was founded in post-Industrial England in $1844^{36}$ to uplift the "spiritual condition of young men engaged in the drapery and other trades by the introduction of religious services among them. ${ }^{{ }^{37}}$ By 1855, the newly conceived World Alliance of YMCAs outlined a new global motto, which emphasizes the need to:

Unite those Young men who, regarding Jesus Christ as their god and savior according to the Holy scriptures, desire to be his disciples in their faith and in their life and to associate their efforts for the extension of his kingdom amongst young men ${ }^{38}$

Crucial here is the fact that moral uplift lift is first geared to men who dwelled in urban areas (working mainly in drapery and trades) then shifts to "young men" throughout the world. From its inception, then, the YMCA was hierarchical in terms of class and race, not to mention gender. This surge in the YMCA's global mission was largely driven by American Evangelism, as Emily S. Rosenberg discusses in Spreading the American Dream: 1890-1945, the YMCA's growing student division preached the following message: “don't stay in this country theorizing, when a hundred thousand heathens a day are dying without hope because we are not there teaching the Gospel to them. ${ }^{{ }^{99}}$ The Evangelical Revivalism of the 1880s and reassertion of masculinity due to the rising number of women in the international missionary field led to the American YMCAs sending their first ever Secretary to unite the YMCA movements in India.

Mary Anne Clawson argues in her influential text Constructing Brotherhood: Class, Gender, and Fraternalism that, "typically fraternal forms of association have reached across boundaries, tending to unite men from a relatively wide social, economic, or religious spectrum. At the same time, fraternalism bases itself on a principle of exclusion from which it derives much of

\footnotetext{
${ }^{36}$ A similar group for women formed in 1855 called the Young Women's Christian Association but operated independently to the YMCA

${ }^{37}$ Howard C. Hopkins. History of the YMCA in North America. New York: Association Press, 1951. Page 4.

${ }^{38}$ Ibid, 78.

${ }^{39}$ Emily S. Rosenberg. Spreading the American Dream: 1890-1945. New York: Wang and Hill, 1982. Page 29.
} 
its power." ${ }^{\prime 10}$ This apparent contradiction emphasizes the fact that "fraternal orders cannot be understood as simply a random assemblage of people." ${ }^{41}$ Prior to 1890, the YMCAs in India were largely loose organizations operating in isolation and did not permit Indian membership. ${ }^{42}$ Thanks to the intervention of the American branch, however, the YMCAs became "open to all young men of good character without distinction of race, rank or religion," a principle that did not result in racial and class equality, as I show in this thesis. ${ }^{43}$

Understood in this way, the YMCA membership rules are contradictory. For example, membership is based on a two-tier system, so that "associate" members could use YMCA facilities but were unable to join YMCA committees which were empowered to make decisions. Only “active” members-a position reserved for avowed Christians-- had decision making power and could advance within the YMCA bureaucracy. While this rule likely ensured a Protestant ${ }^{44}$ majority in leadership, Thomas Winter's Making Men: Making Class: The YMCA and Working Men, 1877-1920 argues that the YMCA was a middle class "manhood making” endeavor, which helped assimilate working class and immigrant men. ${ }^{45}$ The YMCA's work also fell across racial lines, Nina Mjagkij's Light in the Darkness: African Americans and the YMCA, 1852-1946 examines the exclusion of African-American men from joining YMCAs in spite of the universal ethos of brotherhood through manhood advocated by the latter. ${ }^{46}$ Instead, African-Americans continued to be in segregated YMCAs until 1946.

\footnotetext{
${ }^{40}$ Mary Anne Clawson.Constructing Brotherhood: Class, Gender, and Fraternalism. Princeton: Princeton University Press, 1969, page 11.

${ }^{41}$ Ibid.

${ }^{42}$ M.D David. The YMCA and the Making of Modern India: A Centenary History. New Delhi: National Council of YMCAs of India, 1992. Pages 24-25.

${ }^{43}$ As cited in Ibid, page 28.

${ }^{4}$ Coming from the major denominations, Church of England, Baptist, Methodist, Presbyterian. However, Catholics would not be included.

${ }^{45}$ Thomas Winter's Making Men: Making Class: The YMCA and Working Men, 1877-1920. Chicago: University of Chicago, 2002.

${ }^{46}$ Nina Mjagkij. Light in the Darkness: African Americans and the YMCA, 1852-1946. Kentucky: University of Kentucky, 2003.
} 
Mrinalini Sinha asserts that fraternal organizations were no less exclusive when it came to colonial India. ${ }^{47}$ According to Sinha, YMCA clubs functioned to reproduce the comfort and familiarity of "home" for Europeans living in a foreign land. This was in large part due to the fact that expatriate men greatly outnumbered women. ${ }^{48}$ However, Sinha argues that most fraternal clubs did not cater to "rebel” Europeans. This category included "missionaries, single women, and independent-minded intellectuals who were self-conscious about rejecting the norms of AngloIndian social life were not included." ${ }^{\prime 9}$ However, the need for clubs extending to these "rebel" groups was growing; by the 1860s, the Cosmopolitan Club and the Calcutta Club had already begun to cater to both Indian and non-Indian clientele. However, what distinguished the YMCA was its focus on Christian brotherhood. Although the YMCA did not undertake religious conversions, it did work actively alongside missionaries.

Ian Tyrrell's Reforming the World: The Creation of America's Moral Empire examines the activities of evangelical Christian groups and their links to American expansionism from 1870s to the $1920 \mathrm{~s}^{50}{ }^{5}$ Tyrrell argues that the American YMCA justified expansion to India on the basis that "young men of other lands need help" ${ }^{{ }^{51}}$ and connects this to a larger missionary impulse to morally uplift "heathen" societies. ${ }^{52}$ Therefore, the YMCA expansion to India cannot be separated from the larger missionary networks it engaged with. The intersection between missionaries and the YMCA is critical because Brown came from a missionary background with a deep history in

\footnotetext{
${ }^{47}$ Mrinalini Sinha. "Britishness, Clubbability, and the Colonial Public Sphere" in Bodies in Contact: Rethinking Colonial Encounters in World History. Edited by Tony Ballantyne and Antoinette Burton. Durham: Duke University Press, 2005. Pages 183-200.

${ }^{48}$ By 1921, the male population was 112,000 while the female was 45,000.

${ }^{49}$ Mrinalini Sinha. "Britishness, Clubbability, and the Colonial Public Sphere" in Bodies in Contact: Rethinking Colonial Encounters in World History. Edited by Tony Ballantyne and Antoinette Burton. Durham: Duke University Press, 2005. Page 186.

${ }^{50}$ Ian Tyrrell. Reforming the World: The Creation of America's Moral Empire (Princeton: Princeton University Press, 2010.

${ }^{51}$ Ibid, page 86.

${ }^{52}$ Ibid, page 71.
} 
India, ${ }^{53}$ which is helpful in understanding his role as a committee of management member.

Members of the Committee of Management were vetted through local Christian networks, and helped support YMCA secretaries in navigating the foreign field. Although Tyrrell's research helpfully highlights the diverse workings of evangelical Christian groups overseas, it doesn't address how these transnational groups imparted their conceptions of membership. Therefore, it is essential to consider how similar transnational fraternal groups like the Boy Scouts, Freemasons ${ }^{54}$ or the Salvation Army ${ }^{55}$ operated in colonial India.

Similar to Mrinalani Sinha's conception of the colonial recreational club performing a domestic function, Donald Gustav-Wrathall, in Take the Stranger by the Hand: Same-Sex Relations: Same-Sex Relations and the YMCA, argues that overseas YMCA officials and affiliates functioned like a family through "agape," the Christian concept of brotherly love that holds Jesus commanded his disciples to "love one another" and to become "one." ${ }^{56}$ Therefore, in accordance with this discourse, Brown and his YMCA affiliates are not just colleagues, but a family based on Christian fraternal bonds. However, the role of women within this gendered notion of family is largely absent in Gustav-Wranthall's analysis. Consider, for example, the fact that Mrs. Jessop is included within the photograph captioned 1911 Residents YMCA Calcutta (Fig.2), the same photograph that is within the YMCA archive. Her presence suggests that we must address the role of women, however marginalized, in relation to the YMCA's larger male-dominated visual culture.

\footnotetext{
${ }^{53}$ Brown's father had been an Anglican missionary posted in Bengal during the late 1880s. As a result, Brown attended a school for the children of missionaries in England, followed by seminary training at the College of Resurrection. This information was obtained through a newsletter from the Church Missionary Gleaner, January 1, 1915, page 10.

${ }^{54}$ See Jessica L. Harland-Jacobs. Builders of Empire: Freemasons and Imperialism, 1717-1927 (Chapel Hill: University of North Carolina, 2013).

${ }^{55}$ Harald Fischer-Tinè. "Reclaiming Savages in 'Darkest England' and 'Darkest India': The Salvation Army as Transnational Agent of Civilizing Mission” in Civilizing Missions in Colonial and Postcolonial India: From Improvement to Development, edited by Carey Anthony Watt and Michael Mann (New York: Anthem Press, 2011) Fischer-Tinè is currently working on a monograph of the history of the YMCA in India.

${ }^{56}$ John Donald Gustav-Wrathall. Take the Stranger by the Hand: Same-Sex Relations and the YMCA. Chicago: University of Chicago Press, 1998, page 55.
} 
An institutional portrait is the link that connects Brown's personal album to the YMCA public archive. The use of institutional group portraits to convey group cohesion is addressed in Susan Billington-Harper's In the Shadow of the Mahatama: Bishop V.S Azariah and the Travails of Christianity. ${ }^{57}$ Billington-Harper argues that photography played a role in conveying YMCA success overseas, particularly through group portraits which would often be included in annual reports, pamphlets and brochures. Through her discussion of Bishop V.S Azariah's ${ }^{58}$ role as the symbol of YMCA's “Indigenization" ${ }^{59}$ policy, Harper asserts that his Anglican mentors, the Whiteheads, actively pressured Azariah to wear a turban (Fig.5-6), despite his reservations. ${ }^{60}$ Figures 5-6 were part of a series of photographs taken from the Azariah family album, where the Whiteheads tested different combinations of Western and Eastern clothing to convey the right mix of Indo-Christian identity. Wearing a turban in an institutional group portrait (Fig.6) would have represented "indian-ness" to the western audience located at the YMCA headquarters in New York. What Harper emphasizes is that self-presentation through clothing was not an afterthought but rather was at the forefront of signifying success, as symbolized within institutional class portraits, in the YMCA's overseas operation.

Similarly, Ian Tyrrell's Reforming the World: the Creation of a Moral Empire discusses a group portrait taken at a Christian conference organized by the Young People’s Society of Christian Endeavour (YPSCE) in 1909 at Agra (Fig.8). ${ }^{61}$ Tyrrell notes that the inclusion of participants in Indian clothing was heralded by the YPSCE as a sign of "cross-national and cross-

\footnotetext{
${ }^{57}$ Susan Billington-Harper. In the Shadow of the Mahatama: Bishop V.S Azariah and the Travails of Christianity. Grand Rapids: William B. Ederman Publishing, 2000.

${ }^{58}$ The first Indian Ordained Bishop of the Anglican Church, he served as a former YMCA secretary and is well known for having a contentious relationship with Mahatma Gandhi in relation to Nationalism.

${ }^{59}$ In response to growing nationalism and Hindu revivalism, the YMCA adopted a policy to have advance Indian Christians to leadership positions.

${ }^{60}$ Susan Billington-Harper. In the Shadow of the Mahatama: Bishop V.S Azariah and the Travails of Christianity. Grand Rapids: William B. Ederman Publishing, 2000. Page 142.

${ }^{61}$ Ian Tyrell. Reforming the World: The Creation of America's Empire. Princeton, Princeton University Press, 2010.
} 
racial reach., ${ }^{{ }^{62}}$ Tyrrell also discusses Christian arenas where missionaries returning from overseas would display and discuss their progress in the non-western world. Most notable of these venues were Missionary Expositions, which were notorious for reinforcing the narrative of civilizing heathen lands, exemplified by the "Pageant of Darkness and Light." ${ }^{33}$ The Jessops would certainly have been part of this missionary culture, Mr. Jessop having graduated from the YMCA Training College in Springfield, Massachusetts and spending his early YMCA career posted in North America. Christopher Pinney offers an analytic strategy that aims to counter the binary choice that usually emerges in regard to Orientalism. ${ }^{64}$ In "What's Photography got to do with it?" Pinney addresses moments in South Asian photographic history through the arenas of transculturalism, ${ }^{65}$ purification, ${ }^{66}$ and autonomy. ${ }^{67}$ For example, purification's bidirectionality can lean towards “European idioms” or “essentialize Indianness,” aspects that can also intersect with each other. ${ }^{68}$ Pinney's work is essential in engaging with the complexity of visual culture from the colonial era that is present throughout Brown's album.

This thesis argues that Brown and his YMCA affiliates are a fraternal family based on their shared conception of a white, Christian, and middle-class vision of ideal masculinity. By contextualizing the overlap in imagery and keeping in mind the YMCA's policy of "Indianization," I will demonstrate the tension between the YMCA universal ethos of a Christian fraternal family and its implementation in late colonial India.

\footnotetext{
${ }^{62}$ Ian Tyrell. Reforming the World: The Creation of America's Moral Empire. Princeton, Princeton University Press, 2010.

${ }^{63}$ A musical drama showcasing missionary events in foreign lands. For more see Ian Tyrell. Reforming the World: The Creatin of America’s Moral Empire. Princeton: Princeton University Press, 2010. Pages 71-73.

${ }^{64}$ Christopher Pinney. "What's Photography got to do with it?" in Photography's Orientalism: New Essays on Colonial Representation. Edited by Ali Behdad and Luke Gartlan. Los Angeles: Getty Publications, 2013. Pages 33-52.

${ }^{6.5}$ Based on Mary Louise Pratt and James Clifford's conceptions, a contact zone of exchange between colonizer and colonized.

${ }^{66}$ Bruno Latour's use of the term, a bidirectionality but also two separate spheres of influence.

${ }^{67}$ An acknowledgement of local Indian cultural production

${ }^{68}$ Christopher Pinney. "What's Photography got to do with it?" in Photography’s Orientalism: New Essays on Colonial Representation. Edited by Ali Behdad and Luke Gartlan. Los Angeles: Getty Publications, 2013. Page 34.
} 
Chapter 1 focuses on a series of photographs of leisure and Christmas day activities that are included in both Brown and Archer's albums. This chapter assesses the differences and similarities between these albums, particularly focusing on why certain photographs were chosen to be included in Archer's album which was intended for Mrs. Jessop. In doing so, my aim is to address how the depictions of leisure and Christmas activities intersect with YMCA conceptions of manhood and familial photography.

Chapter 2 will focus on a series of pictorialist-inspired photographs of Indian women and school children that are common to Brown and Archer's albums. I will examine how paternalism is visually depicted through Brown and Archer's adherence to literary and artistic conventions associated with pictorialism. In doing so, I will demonstrate how the YMCA served as a facilitator for the photographic network that exists between Brown and his YMCA companions. I will conclude by reflecting on Brown's album and its significance for the field of family photography and its significance to the growing scholarship on the YMCA's India branches and in particular its contribution to the visual culture of colonial India. 

The photograph captioned Residents YMCA Calcutta 1911 appears on a loose page associated with Brown's personal album (Fig.9). It stands out as an example of the genre of school photographs used throughout the YMCA institutional archive. The image depicts three rows of men; in the first two rows, the men are seated, while in the third they are s standing. Although the men depicted do not wear identical uniforms, the lack of uniform does not suggest it is not there. The YMCA was a lay organization ${ }^{69}$ that differed from other international fraternal organizations such as the Salvation Army, ${ }^{70}$ the Boy Scouts, ${ }^{71}$ and the Free Masons, ${ }^{72}$ in that it did not use uniforms to cultivate an image of masculinity and fraternity. This accounts for the diversity in the different styles of suits and jackets worn by those depicted. Instead of a uniform, then, the YMCA members signified belonging through other means, notably through visual conventions. Class photographs often centre around an authoritative figure, most often a teacher. ${ }^{73}$ In this case, the men are gathered around the Calcutta YMCA Secretary, Mr. Jessop, a hierarchical composition that underscored this central figure's superiority, and his function as a surrogate father figure.

Based on the caption's date, we can surmise that Brown was still attending the College of the Resurrection in Mirfield, England at the time the photograph was taken. ${ }^{74}$ He was not yet a member of YMCA Calcutta Committee of Management. ${ }^{75}$ The image accordingly indicates a

\footnotetext{
${ }^{69}$ For more on the social organization of the YMCA see Mayer N Zald. Organizational Change: The Political Economy of the YMCA. Chicago: University of Chicago Press, 1970.

${ }^{70}$ See Harald Fisher-Tine. "Reclaiming Savages in 'Darkest England' and 'Darkest India': The Salvation Army as transnational agent of the civilizing mission' in Civilizing Missions in Colonial and Postcolonial South Asia. Edited by Carey A. Watt and Michael Mann. London: Anthem Press, 2011.Pages 125-165.

${ }^{71}$ See Tammy M. Proctor. "Scouts, Guides, and the Fashioning of Empire," 1919-39 in Fashioning the Body Politic: Dress, Gender, Citizenship. Edited by Wendy Parkins. Oxford; New York: Berg Publishers, 2002. Pages 125-144. ${ }^{72}$ See Jessica L. Harland-Jacobs. Builders of Empire: Freemasons and British Imperialism, 1717-1927. Chapel Hill, University of North Carolina, 2013. Pages 120-149.

${ }^{73}$ Marianne Hirsch. "Class Photos and their Afterlives" in Feeling Photography Edited by Elspeth H. Brown and Thy Phu. Durham and London: Duke University Press, 2014. Page 256.

74 "St. Michaels" in The Church Missionary Gleaner (January 1915) page 10.

${ }^{75}$ Brown makes his official appearance as a Committee of Management member in 1915.
} 
hierarchy between Mr. Jessop and the rest of the men who were under his tutelage, as a "wellgoverned YMCA had to resemble a well-ordered patriarchal household, in which the secretary, in the role of the patriarch, led the way. ${ }^{{ }^{76}}$ Beginning in the late 1880 s, the YMCA institutionalized their conception of what a YMCA secretary's job entailed through the establishment of a YMCA's Training School for Secretaries in Springfield, Massachusetts. ${ }^{77}$ This job included overseeing the management of the YMCA building and tending to the YMCA's mandate of "the improvement of the spiritual, mental, social and physical condition of young men." ${ }^{97}$ The commitment required that Foreign YMCA secretaries place their work commitment above their own personal lives, so much so that John Donald Gustav-Wrathall has coined the term "sacrificial Y-wife." ${ }^{\text {79 }}$ Not only did the Foreign Secretary have to mentor the men under his charge as a surrogate father, his own spouse held a subordinate function in relation to his work. Viewed against this backdrop, Mrs. Jessop’s inclusion in the photograph supplementary, as her role is to support her husband as an auxiliary, rather than by being actively involved in YMCA programming. Though this curious image, drawn from the YMCA's visual culture, is clearly an example of a school photograph, it also evokes familial ideals.

Brown's choice to use "residents" to describe the group of men he is photographed with indicates that he most likely stayed at the YMCA Calcutta dormitory. ${ }^{80}$ This is further reinforced by Brown's entry in Mr. Jessop's autograph book, which lists his address in England rather than in India (Fig.10). YMCA dormitories were first created to provide its middle-class members

\footnotetext{
${ }^{76}$ Thomas Winter. Making Men, Making Class: The YMCA and Workingmen, 1877-1920. Chicago: University of Chicago Press, 2002. Page 109.

${ }^{77}$ William J. Baker. Playing with God: Religion and Modern Sport. Cambridge: Harvard University Press, 2007. Pages 55-57.

${ }^{78}$ Kenneth Latourrette. World Service: A History of the Foreign Work and World Service of the Young Men's Christian Association of the United States and Canada. New York Association Press, pages 21-22.

${ }^{79}$ John Donald Gustav-Wrathall. Take the Stranger by the Hand: Same-Sex Relations and the YMCA. Chicago: University of Chicago, 1998. Pages 91-116.

80 The YMCA largely catered to its membership base which were men of European descent and began to shift post 1910s according to YMCA Indian historian M.D. David. The YMCA and the Making of Modern India: A Centenary History. New Delhi: National Council of YMCAs of India, 1992. Page 97.
} 
affordable housing in response to the demise of boardinghouses in the late nineteenth century. ${ }^{81}$ Unlike a hotel or clubhouse, staying in a YMCA dormitory meant that young men dined, bathed, ate, and socialized in group settings under the supervision of the YMCA secretary, that is, under a controlled environment that Paula Lupkin describes as "loco parentis." ${ }^{82}$ Parents found this Christian mandate appealing and encouraged their young men stay there because the family was not only a source of moral and emotional support, but also youth associations like the YMCA, the Independent Order of Oddfellows, and the Phoenix Society began to resemble "surrogate homes. ${ }^{{ }^{83}}$ For the YMCA secretary, the "emphasis was less on actual living arrangements than on helping the YMCA recruit 'keep up the home feeling associated in his mind with the sweetest recollections." ${ }^{{ }^{84}}$ The YMCA's commitment to providing a "home-like" atmosphere is exemplified through its publicity campaign during World War I where army huts were described as "homes away from home. ${ }^{\sharp 5}$ During his travels back and forth between England and India, Brown would have considered the YMCA to have provided a home- like environment.

Indeed, besides the caption there is only one sign that this photograph was taken in India: the oriental rug, which is distinct for its geometric pattern. Unlike the carpet on which the men are seated, this rug can be seen in its entirety. The choice to place this rug in the foreground of the image suggests that the geographic location of the image is important enough to be hinted at, for otherwise there is little visual indication about where, exactly, the photograph was taken. Its

\footnotetext{
${ }^{81}$ Paula Lupkin. Manhood Factories: YMCA Architecture and the Making of Modern Urban Culture. Minneapolis: University of Minnesota Press, 2009. Page 123.

${ }^{82}$ Ibid, page 125 .

${ }^{83}$ Mary R. Ryan. Cradle of the Middle Class: The Family in Oneida County, New York, 1790-1865. New York: Cambridge University Press, 1981. Page 176.

${ }^{84}$ Paul S.Boyer. Urban Masses and Moral Order in America, 1820-1920. Cambridge: Harvard University Press, 1978. Page 124.

${ }^{85}$ As cited in Jeffrey S. Reznick. Healing the Nation: Soldiers and the Culture of Caregiving in Britain During the Great War. Manchester: Manchester University Press, 2004.Page 21.
} 
Indianness, then, is hinted at in the rug; but otherwise, the exterior space resembled that of YMCA building locations.

Standing directly behind Mr. Jessop in this photograph, Brown poses with his arm linked to the man to his right, in a vision of Christian fraternal love (agape), ${ }^{86}$ a principle promoted by the YMCA for its helpfulness in evangelical outreach and in cultivating group solidarity. Such a vision in effect promoted homosocial bonds, which are further exemplified by the man seated on Mr. Jessop's right, who cradles another man between his knees. ${ }^{87}$ After 1900, however, the YMCA decreased its emphasis on homosocial friendship in response to anxieties about homosexuality, ${ }^{88}$ which peaked in the wake of a scandal at the Portland, Oregon YMCA, which broke out when twenty YMCA's Protestant middle-class members and staff were arrested on charges of "indecent and degenerate conduct" ${ }^{\$ 9}$ thereby casting a cloud of shame to the YMCAs reputation as a respectable middle-class Christian establishment. We can observe, perhaps, signs of this anxiety in the photograph, for not all of the men here seem as enthusiastic as Brown was about expressing their fraternal affection; many have chosen to cross their arms instead, to decrease their physical proximity to men, arguably, in a gesture of repudiation.

Unlike the image in the YMCA archive, Brown has chosen to place his image in his personal album. In doing so, he is placing it in the realm of the familial. Many of the men photographed in this image reappear in Brown's photographic images. Although their visual identity is unknown, their photographic and institutional connection to Brown is. Included in this

\footnotetext{
${ }^{86}$ Biblical origin of agape can be traced to "we love him, because he first loved us" (I John 4:19) "If we love one another, God dwelleth in us, and his love is perfected in us" (I John:12).

${ }^{87}$ Homosocial bonds as expressed through physical proximity between men exhibited in posed portraits, as analyzed in David Dietcher Dear Friends: American Photographs of Men Together. New York: Harry N. Abrams, 2001. Also see Luke Gartlan "Dandies on the Pyramids: Photography and German-Speaking Artists in Cairo” in Photography's Orientalism: New Essays on Colonial Representation, edited by Ali Behdad and Luke Gartlan. Los Angeles: Getty Research Institute, 2013, pages 129-152.

${ }^{88}$ John Donald Gustav-Wrathall. Take the Stranger by the Hand: Same-Sex Relations and the YMCA. Chicago: University of Chicago Press, 1998. Page 63.

${ }^{89}$ Ibid, page 162 .
} 
group are W. Archer, ${ }^{90}$ A. Hodgson ${ }^{91}$ and E.M Moffatt. ${ }^{92}$ Both W. Archer and A. Hodgson were on the YMCA Calcutta Committee of Management with Brown. E.M. Moffatt was a YMCA Secretary posted in Allahabad from 1911-1916. What all of these men have in common is that they are in communion with evangelical Christian churches, one of the defining characteristics needed to climb the ranks of the YMCA institutional hierarchy. The photographic circulation of imagery associated with this group thus crosses between personal albums, the YMCA institutional archives, and National Geographic Magazine. In doing so, the images acquire new meanings in different contexts and for different audiences.

I begin with this photograph because it raises important questions about the intersections between institutional archives and family albums, as an artifact that appears both in the YMCA's visual records and in Brown's personal collection. According to Marianne Hirsch, school photographs, as primary signifier of institutional belonging, "do more than certify a step in the trajectory of ideological incorporation. They also instantiate the institutional process that interpellates the individual into a group identity." ${ }^{93}$ This institutional portrait accordingly connects Brown to YMCA conceptions of masculinity and visually marks his membership to the YMCA group identity as white and Christian.

To grasp how “'families' are shaped by the individual responses to the ideological pressures deployed by the familial gaze, ${ }^{94}$ and the ways that this familial gaze is influenced by ideologies, we must first understand the YMCA's history in Victorian England. John Tosh states that, "The

\footnotetext{
${ }^{90}$ Brown's fellow Committee of management member. Archer gifts a photograph album dedicated to Mrs. Jessop. The album contains imagery that is almost identical to Brown's album.

${ }^{91}$ Brown's fellow Committee of Management member. Images credited to A. Hodgson appear in Archer's scrapbook dedicated to Mrs. Jessop, and Mrs. Jessop’s National Geographic article.

${ }^{92}$ YMCA secretary of Allahabad (1910-1916), Images credited to E.M Moffat appear in Archer's scrapbook dedicated to Mrs. Jessop and Mrs. Jessop's National Geographic article.

${ }^{93}$ Marianne Hirsch and Leo Spitzer. "School Photos and their Afterlives" in Feeling Photography Edited by Elspeth H. Brown and Thy Phu. Durham and London: Duke University Press, 2014. Page 257.

${ }^{94}$ Ibid.
} 
Young Men's Christian Association...was intended to provide social and reading facilities in towns for apprentices and shop assistants who lacked the amenities of a regular home. ${ }^{95}$ By adding a library and reading rooms, the evangelical YMCA founders offered their fellow single, unmarried, clerks a Christian space that stirred men away from the "moral dangers" of the city, but also allowed men a chance to cultivate their masculinity based on fraternal club culture which their social and economic position would not have afforded them. ${ }^{96}$ One of the ways fraternal clubs offered an "alternative site for domestic life for men" ${ }^{97}$ was by replicating the familiarity of English clubs overseas through the extension of membership reciprocity to men in colonial settings who were separated from their families. ${ }^{98}$ Similarly, the first YMCA in Calcutta opened in 1854 and was reserved for Europeans and Anglo-Indians ${ }^{99}$ who wanted to transplant the familiarity of the YMCA experience to India, and looked to London as their "Parent Association." YMCA's conception of a globalized identity based on a fraternal Christian brotherhood was institutionalized with the establishment of the YMCA's First World Conference in Paris in 1855, which states the organization's primary mission as:

\footnotetext{
${ }^{95}$ John Tosh. A Man's Place: Masculinity and the Middle-Class Home in Victorian England. New Haven: Yale University Press, 1998. Page 107.

${ }^{96}$ Geoffrey D. Spurr. "The London YMCA: A Haven of Masculine Self-Improvement and Socialization for the LateVictorian and Edwardian Clerk” in the Canadian Journal of History 37:2 ( August 2002) page 290-301.

${ }^{97}$ Amy Milne-Smith. London Clubland: A Cultural History of Gender and Class in Late-Victorian England. New York: Palgrave Macmillan, 2011. Page 111. Milne smith is extending John Tosh's argument of homosocial spaces offering an escape from Victorian domestic life. See John Tosh's "Home and Away: The Flight from Domesticity in Late-Nineteenth Century in England Re-visited” in Gender \& History 27:3 ( November 2015) pages 561-575 Also see A Man's Place: Masculinity and the Middle-class home in Victorian England. New Haven: Yale University Press, 1999. Anthony Rotundo also connects homosocial club culture as an alternative formation of family, for more see Anthony Rotundo. American Manhood: Transformations in Masculinity from the Revolution to the Modern Era. New York: Basic Books, 1993. Especially pages 143-146.

${ }_{98}^{98}$ Amy Milne-Smith. London Clubland: A Cultural History of Gender and Class in Late-Victorian England. New York: Palgrave Macmillan, 2011. Page 138.

${ }^{99}$ Prior to 1919, Anglo-Indian was used to describe British residents that settled in India. After this date, Anglo-Indian was widely used and was legally defined as people with mixed parentage who had a European ancestor in their male line of inheritance. For more see Laura Bear "Public genealogies: Documents, Bodies and Nations in Anglo-Indian Railway Family Histories” in Contributions to Indian Sociology 35:3 (October 2001) pages 355-388.

${ }^{100}$ M.D David. The YMCA and the Making of Modern India: A Centenary History. New Delhi: Association Press, 1992. Page 18.
} 
To unite those young men, who regarding Jesus Christ as their God and Savior according to the Holy Scriptures, desire to be his disciples in their doctrine and in their life, and to associate their efforts for the extension of his kingdom amongst young men. ${ }^{101}$

The call to extend Christ's "kingdom amongst young men" can be understood as a call to spread Christian unity by evangelical groups during the late 1880 s religious revivalism. ${ }^{102}$ The American YMCA's organizational structure was strengthened through its creation of the YMCA training school and through the financial backing by business tycoons like the Rockefellers. Meanwhile, the YMCA's student wing's call for the "evangelization of the world in one generation" ${ }^{103}$ resulted in an inter-denominational meeting of all the missionary workforce, which called upon the American YMCA to intervene. ${ }^{104}$ After this meeting, the American YMCA sent David McConaughy to India to unite and organize the YMCA movement beyond its English conception, which preached to the converted rather than actively targeted non-Christians. ${ }^{105} \mathrm{By}$ preaching and targeting non-Christians, the YMCA would plant the seeds to conversion rather than administer it. In 1891, the Madras YMCA opened membership to all “ young men of good character, without distinction or race, rank or religion." ${ }^{106}$ However, the transition from a Western dominated YMCA leadership to an Indigenized one would not begin until the early $1910 \mathrm{~s} .{ }^{107}$

This tension is manifest in Brown's class photograph, a genre that has the potential to subvert the visual cohesion it is meant to represent by capturing contradictions. ${ }^{108}$ In late Imperial

\footnotetext{
${ }^{101}$ Clarence P. Shedd. History of the World's Alliance of the Young Men's Christian Associations. London: S.PC.K., 1955. Page 133.

${ }^{102}$ Ruth Rouse and Stephen Charles Neill. A History of the Ecumenical Movement, 1517-1948.

${ }^{103}$ Ian Tyrell. Reforming the World: The Creation of America's Moral Empire. Princeton: Princeton University Press,2010. Page 24.

${ }^{104}$ Ian Tyrell. Reforming the World: The Creation of America's Moral Empire. Princeton: Princeton University Press, 2010. Page 86.

${ }^{105}$ Ibid, page 89.

${ }^{106}$ M.D David. The YMCA and the Making of Modern India: A Centenary History. New Delhi: Association Press, 1994. Page 28.

${ }^{107}$ Ibid, page 20 .

${ }^{108}$ Marianne Hirsch and Leo Spitzer." School Photos and their Afterlives” in Feeling Photography Edited by Elspeth H. Brown and Thy Phu. Durham and London: Duke University Press,2014. Page 257.
} 
India, physical appearance and ancestry alone did not connote whiteness; therefore, the visual ethnic integration depicted in this image understood as a collective of white men makes it difficult to see the boundaries of whiteness. ${ }^{109}$ What appears to be an ethnically integrated photograph may not be so.

As noted above, the YMCA engaged in outreach geared towards railroad and army men among the lower-middle class and those who were "poor whites." ${ }^{110}$ In this regard, the YMCA operated in a manner akin to other institutions like "military cantonments for soldiers and the Railway Institutes for Eurasians in setting the limits of, as well as determining the visibility of whiteness in colonial India." ${ }^{111}$ The function of class photographs can be related to the larger structure of "various relational, cultural, and institutional processes-such as 'looking' and photography" ${ }^{\prime 12}$ that create a "family" as is an "affiliative group." ${ }^{\prime 13}$ If we consider Brown and his YMCA companions as an affiliative group expressing a shared identity through the class photo, to what extent is the YMCA constructed as a family?

Marianne Hirsch observes that, "Family photographs locate themselves precisely in the space of contradiction between the myth of the ideal family and the lived reality of family life." ${ }^{14}$ This chapter traces the intersections between the YMCA's visual archives and personal albums, and explores how these intersections draw on and promote familial discourses that project a vision

\footnotetext{
${ }^{109}$ Elizabeth Buettner. Empire Families: Britons and Late Imperial India. Oxford: Oxford University Press, 2004. Page 10.

${ }^{110}$ Buettner argues that the boundaries between lower middle-classes and the "poor whites” were blurry See Elizabeth Buettner. Empire Families: Britons and Late Imperial India. Oxford University Press, 2004. Page 12-1. Also see Ann Laura Stoler's discussion of "poor whites" in Carnal Knowledge and Imperial Power: Race and the Intimate in Colonial Rule. Berkeley: University of California Press, 2010. Pages 36-40.

${ }^{111}$ Mrinalini Sinha. "Britishness, Clubbality, and the Colonial Public Sphere" in Bodies in Contact: Rethinking Colonial Encounters in World History. Edited by Antionnette Burton and Tony Ballantyne. Durham and London: Duke University Press, 2005. Page 188.

${ }^{112}$ Marianne Hirsch. Family Frames: Photography, Narrative, and Postmemory. Cambridge: Harvard University Press, 1997. Page 10.

${ }^{113}$ Ibid.

${ }^{114}$ Marianne Hirsch. Family Frames: Photography, Narrative, and Postmemory. Cambridge: Harvard University Press, 1997. Page 8.
} 
of ideal white, middle-class masculinity. By examining posed portraits of Brown and his YMCA family, specifically those that depict him participating in acceptable forms of recreation and in socially sanctioned activities, during this transitional period of the YMCA expansion to India, I will demonstrate how these images visually construct YMCA white Christian masculinity and in doing so maintain racial and class hierarchies.

\section{$\underline{\text { Seashore Excursions }}$}

Images from a seashore excursion to Puri, located in the western state of Odisha (formerly called Orissa), appear in albums belonging to Brown (Fig.11) and to W. Archer (Fig.12). Brown's photographs from this series depicting recreational activities are captioned Puri in the surf(Fig.13) and On the shore at Puri (Fig.14) and depict him with his YMCA companions along with their Indian guides at the seashore.

In an album belonging to Archer, there is a photograph captioned Surfbathing, which closely resembles figure 13. Because Archer's album is dedicated to Mrs. Jessop, it was probably a gift for both of the Jessops. ${ }^{115}$ Many late Victorian albums were meant as gifts for the couple though the were only dedicated to the wife. ${ }^{116}$ All three of these photographs depict Brown, Mr. Jessop, and their YMCA companions with their Indian guides in the water and posed along the seashore. While Brown's image measures $41 / 2 \times 6 \frac{1}{2}$ inches, Archer's is significantly larger at $41 / 4$ inches x 8 1/2 inches. By 1906, Kodak had introduced the largest of the daylight loading Kodak roll film cameras, which produced images as large as Brown's. ${ }^{117}$ Brown most likely used this camera or an English variation such as the Ensign box made by Houghton Ltd. ${ }^{118}$ Archer's image

\footnotetext{
${ }^{115}$ Dr. Deepali Dewan alerted me to this Victorian custom.

${ }^{116}$ Ibid.

${ }^{117}$ Todd Gustavson. Camera: A History of Photography from Daguerreotype to Digital. New York and London: Sterling Publishing, 2007.Page 157.

${ }^{118}$ Brian Coe and Paul Gates. The Snapshot Photograph: The Rise of the Popular Photograph, 1888-1939. London: Ash \& Grant, 1977. Page 25,30.
} 
size is not uniformly cut and indicates that he most likely made a contact print from a negative. At the end of the First World War, there were three ways to enlarge images: by using magic lanternstyle enlargers; by using a photograph to make a negative; and by using a camera and box resembling a two-camera system. ${ }^{119}$

Both Brown and Archer caption their activity in the water as "surf-bathing." Prior to the international popularization of surfing after World War II-a sport that enabled an enthusiast to ride waves with a board-there was not yet a standardized term to describe the activity, which was sometimes known as 'surf-board swimming,' as 'surf bathing,' or 'surf shooting." ${ }^{120}$ When the photo was taken, commercially produced surf-boards were a rarity; we can surmise, then, that the long narrow raft-like vessel here would most likely have been created locally. ${ }^{121}$

Like swimming, however, surf-bathing provoked the contentious issues of public exposure and indecency, wherein middle-class men were concerned about exposing their bodies in the presence of women. ${ }^{122}$ To allay these concerns, the exposed surf-bathing body had to be redefined along middle-class masculine lines; it did so by drawing on discourses of eugenics, ${ }^{123}$ American Imperialism, ${ }^{124}$ and life-saving, all of which were embedded within the YMCA's physical education

\footnotetext{
${ }^{119}$ George Eastman House. "Enlarging”. Notes on Photographs. Accessed online at http://notesonphotographs.org/index.php?title=Enlarging

${ }^{120}$ Scott Laderman. Empire in Waves: A Political History of Surfing. Berkeley: University of California Press, 2014. Page 36.

${ }^{121}$ The manufacturing and standardization of surf-boards internationally began at the end of World War II. The first surf boards were commercially sold in Hawaii as early as 1901, some of these Hawaiian made boards were used internationally. For example, Hawaiian boards were were used in Australia in 1908 but it was not the norm. For more see Andrew Warren and Chris Gibson. Surfing Places, Surfboard makers: craft, creativity, and Cultural Heritage in Hawai’i, California, and Australia. Honolulu: University of Hawai’i Press, 2014. Pages 55-67.

${ }^{122}$ Cameron White. "Save us from the Womanly Man: The transformation of the Body on the Beach in Sydney" in Men and Masculinities 10:1 (2007) page 25.

${ }^{123}$ Ramsland, John. "They ride the surf like gods: Sydney-side beach culture, life-saving and eugenics 1902-1940" in $A$ Race for Place, edited by Martin Crotty, John Germov, and Grant Rodwell. New Castle: University of New Castle, 2000 .

${ }^{124}$ Scott Laderman. Empire in Waves: A Political History of Surfing. Berkeley: University of California Press, 2014. Pages 8-40.
} 
program. ${ }^{125}$ Closer consideration of these types of photographs in Brown's personal album reveal the ways these discourses play out.

Combining athletics and leisure was part of the YMCA's physical education program institutionalized in the late 1880s. The YMCA's conception of Muscular Christianity, ${ }^{126}$ the belief that a vigorous body was integrally linked to a stalwart spirituality, infused leisure with the promotion of exercise to combat disease, feminization, and urban vice. At the same time the communal aspect of leisure and team-based sports were designed to strengthen the bonds between members and the YMCA secretary and in turn bring everyone-or rather white subjects--closer to God. Michael S. Kimmel argues that embracing sporting culture, as the YMCA was doing "was not just 'masculinity' that was reconstituted through sports, but a particular kind of masculinity- white and middle class where the body served as proof of one's masculinity." ${ }^{127}$ The YMCA emphasized athletic leisure, holding fast to the idea that instilling virtue entailed a moral duty to strengthen the body. Surf-bathing was one of numerous recreational activities that YMCA members took up, in line with this belief.

The YMCA's choice to incorporate "surf-bathing” rather than swimming is a conscious effort to align their activity with surf-bathing, which was closely associated with life-saving. Lifesaving clubs developed in the 1890s in response to the large number of drowning deaths as the popularity of leisure seashore holidays increased. ${ }^{128}$ Beginning in 1895 , life-saving and swimming

\footnotetext{
${ }^{125}$ Douglas Booth. "In-Between the Flags: Reflections on a Narrative of Surf Life Saving Australia" in Rethinking History 12:2 (June 2008).

${ }^{126}$ The term "Muscular Christianity” first appeared in a review of Charles Kingsley's novel Two Years Ago (1857) published in The Saturday Review. It was subsequently used to describe and popularize the novel Tom Brown's Schooldays (1856) by Thomas Hughes. Its biblical origins are in the New Testament, most notably Corinthians 6:1920, and Mark 11:15 which emphasize physical health and exertion.

${ }^{127}$ Michael S. Kimmel. "Consuming Manhood: The Feminization of American Culture and the Recreation of the American Male Body, 1832-1920” in The History of Men: Essays in the History of American and British Masculinities. Edited by Michael S. Kimmel. New York: State University of New York, 2005, page 58

${ }^{128}$ Susie Parr. The Story of Swimming: A Social History of Bathing in Britain. Stockport: Dewi Lewis Media, 2011. Page 83.
} 
became part of the curriculum at the YMCA Training School. The YMCA began teaching lifesaving in 1904, and by 1910 began a national program to teach America how to swim. ${ }^{129}$ As a YMCA-trained Secretary, Mr. Jessop would have been responsible for teaching these physical activities to young men like Brown and his companions. Life-saving was akin to surf-bathing because both involved knowledge of aquatics and the body. The YMCA's connection to surfbathing also coincides with the establishment of the first foreign American YMCA in Honolulu in 1869. ${ }^{130}$ Additionally, the YMCA's Physical Education mastermind was Luther Gulick, who was born to well-known missionaries in Hawaii. ${ }^{131}$ Consistent with surf-bathing's newly acquired status as morally decent, Brown and his party's shorter and tighter suits would have been considered more athletic and acceptable-even though they exposed more of the body--than the white "knee to neck" attire worn by Mr. Jessop. Compared to white attire, darker suits were desirable because they were less transparent when wet, and therefore more appropriate to wear in public. ${ }^{132}$

Hints of the potential for impropriety can nevertheless be discerned if we consider the significance of the setting. Puri was an unusual location for a holiday; its proximity to the temple of Jagannath connected it deeply to Hindu culture and its hot climate made it an unpopular destination for elite Europeans in India. A more conventional setting for leisure activities would have been hill stations, which the British constructed for the purpose of a creating a home-like atmosphere, featuring man-made lakes meant to visually emulate the English countryside. These hill stations also afforded privacy for leisure activities without the presence of Indians. ${ }^{133}$ Moreover, surf bathing cannot be done in an environment where perils such as tides, sand spits and currents

\footnotetext{
${ }^{129}$ Ibid, page 131.

${ }^{130}$ Ibid, page 98.

${ }^{131}$ Surfing was an indigenous cultural practice in the Polynesian Islands. It was banned along with other cultural practices like Hula by Protestant Missionaries until the late 1890s.

${ }^{132}$ Christopher Love. "Swimming and Gender in the Victorian World" in The International Journal of the History of Sport.24:5 (2007) pages 586-602.

133 Dane Kennedy. Magic Mountains: Hill Stations and the British Raj. Berkeley: University of California Press, 1996. Pages 1-16.
} 
are not known. Therefore, Indian guides would be needed because of their local knowledge of the water, a need all the more pressing because this was the Jessops's first YMCA posting abroad. The presence of Indian men and their racially marked masculinity posed a challenge to the middleclass men's decorum, their sense of ideal bodily display.

Consider this photograph from Archer's album, which includes Mr. Jessop on the left corner on a raft-like vessel flanked by Indian guides on either side (Fig.12). He is joined by another YMCA member in an athletic style suit. Three Indian guides help with this activity. Although this photograph was taken from a distance, the YMCA members are turned towards he camera, a pose that is significant because their heads are not facing the water as they should be if actually "surf-bathing," suggesting ambivalence as to the exact subject of this photograph, notwithstanding the caption.

Figure 14 is a close-up portrait of both Indian guides and Brown's party. Brown's party of six is seated on the ground, while standing behind them are their Indian guides. The heat from the sun can be inferred through the YMCA party's poses and expressions. Each YMCA member faces a different direction although they are sitting directly on the sand. Brown is depicted first on the right, with a towel sheltering his head. In contrast to Brown and his YMCA companions, the Indian guides wear dhotis. ${ }^{134}$

Europeans visiting India for the first time may have been appalled by the revealing nature of dhotis and loincloths. ${ }^{135}$ The YMCA's idealization of muscular masculinity, however, entailed an appreciation of muscular bodies and an acceptance of a degree of male nudity. YMCA publications promoted exercises that would build muscles and ideal measurements of the body through photographs of men in underwear. YMCA publications promoted exercises that would

\footnotetext{
${ }^{134}$ Unstitched cloth that is tucked, similar to a loin-cloth.

${ }^{135}$ Emma Tarlo. Clothing Matters: Dress and Identity in India. Chicago: University of Chicago, 1996.Pages 32-39.
} 
build muscles and ideal measurements of the body through photographs of men in underwear. For example, Bernarr MacFadden, publisher of the magazine Physical Culture faced obscenity trials in 1907 for sexually suggestive photographs of nude and semi-nude men. ${ }^{136}$ Yet, the YMCA published similar photographs but did not face indecency charges apparently because its images were used not for salacious purposes but rather to show young men what an ideal physique looked like. ${ }^{137}$ For the YMCA's membership base, achieving a common goal of an ideal physical appearance allowed members to connect fraternally. ${ }^{138}$

The practice of comparing and admiring male bodies would not have extended to the Indian guides. Harald Fischer-Tine best describes the YMCA's view of Indian men as the "somatic orientalism" ${ }^{139}$ wherein "native bodies... [are] fundamentally different and 'hopelessly defective." In turn this view is based on the YMCA's philosophy of physical education, which linked sickness to sin. In this spirit, the YMCA equated the religion of Indian guides with sickness because Hinduism's association with asceticism led "to incalculable losses in impaired racial vitality and physical suffering." ${ }^{141}$ This prejudice posed a challenge because the YMCA needed to adapt to Indian cultural practices regarding the body if they wanted to recruit young Indian men into the YMCA's Christian brotherhood. In fact, the first American YMCA Physical Education Director

\footnotetext{
${ }^{136}$ Born Bernard Macfadden but changed his name to Bernarr because it sounded stronger like a lion's roar for more see Amy Aronson and Michael S. Kimmel (eds) Men and Masculinities: A Social, Cultural, and Historical Encyclopedia. Vol I A-J. Santa Barbara: ABC-CLIO, 2004. Page 477-478.

${ }^{137}$ John Donald Gustav-Wrathall. Take the Stranger by the hand: Same-Sex Relations and the YMCA. Chicago: University of Chicago, 1998. Page 151. Also see Clifford Putney's discussion of the homoerotic nature of YMCA muscular imagery in Muscular Christianity: Manhood and Sports in America, 1880-1920. Cambridge: Harvard University Press, 2001. Page 93.

${ }^{138}$ John Donald Gustav-Wrathall. Take the Stranger by the hand: Same-Sex Relations and the YMCA. Chicago: University of Chicago, 1998. Page 150.

${ }^{139}$ Harald Fisher-Tinè is building on Joseph S. Atler's conception of "somantic nationalism” for more see Joseph S. Atler "Somantic nationalism: Indian Wrestling and Militant Hinduism” in Modern Asian Studies 28 (1994) pages 557-588.

${ }^{140}$ Harald Fisher-Tiné."Fitness for Modernity?-The American YMCA and Physical Education Schemes in LateColonial South Asia (c.1890-1940)” forthcoming publication in Modern Asian Studies. Scholar is currently working on a monograph of the YMCA in India.

${ }^{141}$ Ibid.
} 
introduced the practice of asana (postures) in the YMCA's Training Colleges in an effort to fuse eastern and western physical activities in the early $1920 \mathrm{~s} .{ }^{142}$

This context helps us understand how an ethos of indigenization likely lies behind the headgear worn by members of Brown's party and the Indian guide standing behind Brown. When worn with bathing attire, these hats suggest an aquatic function. However, they are not associated with Edwardian bathing culture; instead they appear to be made from a woven material, most likely straw. ${ }^{143}$ Whereas the Indian guide wears his hat further back on his head, the YMCA group uniformly wear their hats upright. This further suggests that the hats worn by the YMCA party were most likely Indian in origin. The YMCA's indigenization of Muscular Christianity was not a one way process; indeed, YMCA literature influenced the development of a modernized hatha yoga, ${ }^{14}$ and rival nationalistic offshoots like the Young Men’s Hindu Association. ${ }^{145}$ Mr. Jessop's autograph book also contains the signature of J.N. Farquhar, one of the key proponents of the YMCA's indigenization strategy based on presenting Hinduism through a Christian lens. ${ }^{146}$ Therefore, a visit to the Puri seashore also crosses over with the YMCA's interest in adapting its Christian message in India.

At the same time, what makes this photograph unusual is that although servants are included in many family albums from the colonial era, in the case of Brown and his YMCA party, these Indian men are not domestic servants in a household. Rather, they literally are guides indispensable to the YMCA's mandate to make manhood. In this case, Indian men offer the

\footnotetext{
${ }^{142}$ Mark Singleton. Yoga Body: The Origins of Modern Posture Practice. Oxford: Oxford University Press, 2010. Page 92.

${ }^{143}$ Dr. Alexandra Palmer, Textile Curator at the Royal Ontario Museum pointed this out.

${ }^{144}$ Joseph S. Atler. "Yoga at the Fin de Siecle: Muscular Christianity with a 'Hindu' Twist" in The International Journal of the History of Sport 23:5 (August 2006) page 769.

${ }^{145}$ V.Sankaran Nair. Swadeshi Movement: The Beginnings of Student Unrest in South India. Delhi: Mittal Publications, 1985. Page 26.

${ }^{146}$ See Constable, Phillip. "Scottish Missionaries, 'Protestant Hinduism' and the Scottish Sense of Empire in Nineteenth and Early Twentieth-Century India” in The Scottish Historical Review 86:2 ( December 2007), pages 278313. Also see Eric J. Sharpe. Not to Destroy but to Fulfill: The Contribution of J.N Farquhar to Protestant Missionary Thought in India before 1914. Lund: C.W.K Gleerup, 1965.
} 
means by which white men could attain their masculinity. Yet the photograph attempts to minimize this unsettling role reversal by marginalizing the Indian men to peripheral positions in the composition. Specifically, Brown captioned this photograph On the Shore at Puri. By including the guides in this portrait but relegating them to the background, Brown reinforces the Indian guide's function as a colonial backdrop. The photograph employs a visual rhetoric that chips away at the influence of the guides, stressing that at stake in this excursion is white masculinity, while minimizing the importance of Indian men in providing guidance in this process.

This fraught process of indigenization also helps explain the hierarchical composition of this photograph. To be sure, setting up for this photographic group shot would have required planning, as the six YMCA men had to position themselves on the sand and avoid the glare of the sun. Meanwhile, they would have needed to maintain distance from the Indian guides and then coordinate the moment they would pose directly before the image is captured. This may explain why many of the YMCA members are looking away from rather than at the camera. Folding cameras could adjust the shutter speed, so that standing still for an image to register would not have been a concern. Although the Indian guides are included in the portrait, they stand behind Brown's YMCA group. Their very inclusion in Brown's photograph makes them subject to the same rules of "decorum and camera-consciousness as their dominant male subjects." ${ }^{47}$ This explains how each guide's stance is different from the rest of the group although they are standing together. Notably, the guide standing directly behind Brown is the only man in the photograph that directly gazes at the photographer; he does not have his eyes lowered or to the side. Lowering one's eyes was also a sign of respect, especially in relation to female employers. ${ }^{148}$ The body

\footnotetext{
${ }^{147}$ Arjun Appadurai. "The Colonial Backdrop” in Afterimage 24:5 (1997). Page 4+ Academic OneFile.

${ }^{148}$ Fae Ceridwen Dussart." That Unit of Civilization' and 'the talent peculiar to women': British Employers and their servants in the nineteenth-century in the Indian Empire" in Identities: Global Studies in Culture and Power 22:6 (2015) pages 706-721.
} 
language of the guide in the middle of the photograph reinforces his subservient position as he tucks his hands behind his back. The guide in the left corner has crossed his arms under his armpits and appears to be looking towards the floor. The poses adapted by the guides can also be attributed to their camera-consciousness and lack of familiarity with such middle-class conventions as the smile ${ }^{149}$ and indulgence of leisure activities ${ }^{150}$ that Brown and his YMCA party would have understood. Yet, Brown and the YMCA party neither acknowledge the camera nor do they smile. The person next to Brown is the only one who gestures to the photographer, along with the Indian guides that face and look towards the camera. The poses and expressions of the Indian guides do not, then, suggest complete subservience. Given this ambivalence on the part of the Indian guides, it is significant that the album dedicated to Mrs. Jessop includes an image where these men are featured less prominently. The relationship between Brown and his YMCA companions towards the Jessops is one of respect-- the institution encouraged intergenerational bonding to ensure cohesiveness--so it follows that the visual record retains this gesture arguably through its exclusion of images that even hinted at resistance toward this convention. ${ }^{151}$ This helps to explain why figure 12 was dedicated to the Jessops.

\section{Christmas in Calcutta}

Brown was part of a larger population of single European men that outnumbered women significantly until as late as $1921 .^{152}$ Clubs played an important "domestic function" in colonial clubs, and in doing so maintained the boundaries of "legitimate whiteness," which was based on

\footnotetext{
${ }^{149}$ Christina Kotchemidova. "Why we Say "Cheese" the Smile in Snapshot Photography" in Critical Studies in Media Communication 22:1 ( March 2005) page 3.

${ }^{150}$ Nancy Martha West. Kodak and the Lens of Nostalgia. Charlottesville and London: University of Virginia Press, 2000. Page 40.

${ }^{151}$ John Donald Gustav-Wrathall. Take the Stranger by the Hand: Same-Sex Relations and the YMCA. Chicago: University of Chicago, 1998. Pages 84-89.

${ }^{152}$ "the total European population in India comprised approximately 45,000 women and some 112,000 men,"in figure ed in Mrinalini Sinha. "Britishness, Clubbability, and the Colonial Public Sphere” in Bodies in Contact: Rethinking Colonial Encounters in World History. Durham and London: Duke University Press, 2005. Edited by Antoinnette Burton and Tony Ballantyne.Page 185.
} 
elite membership. ${ }^{153}$ These posed portraits of Brown were taken at meal times, and confirm his membership to the YMCA family. Julia Hirsch argues that pictures of families adhering to custom and religion also "subordinate a personal sense of time and place to the demands of the ritual." ${ }^{154}$ Because the YMCA connects mind, body, and soul, the organization emphasizes social rites as a key part of cultivating manhood. Against this context, these images of Brown on Christmas have personal, religious, and customary functions.

Photographing the family at mealtime has a visual history prior to the advent of amateur photography, for meal times usually record other events- anniversaries, religious holidays, weddings. ${ }^{155}$ Brown photographed Christmas activities with his YMCA family during Christmas time in Calcutta (Fig.15-18). Consider, for example, this loose page from Brown's album containing two images depicting mealtimes at Christmas (Fig.15). Figure 16 is captioned Xmas Breakfast YMCA 1910 and below it figure 17 is captioned Tiffin at the Bot:Gdns 1910 Xmas Day.

Figure 16 depicts Brown and his YMCA family seated around an elaborately spread table. Christmas was an important day in colonial club food culture, when festive dinners and banquets were held at clubs, often bringing together a large number of single men. The platters of food have been carefully arranged and put together, an indication of the importance of this day. Brown and his YMCA companions are seated around the table; they lean slightly inward in order to fit within the camera's frame. Mr. Jessop and Mrs. Jessop are seated at the head of the table, with a group of women and children surrounding them. Brown is seated fifth from the left side of the table and his face can be clearly seen. Unlike those who are closer to the camera, including Mrs. Jessop, Brown's face is not blurred by the flash. By 1910, shooting interiors was still a challenge. This

\footnotetext{
${ }^{153}$ Mrinalini Sinha." Britishness, Clubbability, and the Colonial Public Sphere” in Bodies in Contact: Rethinking Colonial Encounters in World History. Durham and London: Duke University Press, 2005. Edited by Antoinnette Burton and Tony Ballantyne. Page 185.

${ }^{154}$ Julia Hirsch. Family Photographs: Content, Meaning and Effect. New York and Oxford: Oxford University Press, 1981,page 59 .

${ }^{1.55}$ Ibid.
} 
image most likely used a magnesium ribbon in order to illuminate the room, for flashbulbs and photoflood lamps were not on the market until the $1930 \mathrm{~s} .{ }^{156}$

Brown is seated on the left side of the table and is second from the corner. He gazes directly at the camera. Like the rest of his YMCA companions he has worn a white collar for this special occasion. White collars were so associated with a higher class that during the 1840s detachable white collars were invented and used by working class man to portray an outward middle class respectability. ${ }^{157}$ White attire is also worn by the Indian servants that occupy the outer edges of this image. Unlike the Puri images of the Indian guides, who appear in dhotis, servants working within a home were uniformed. ${ }^{158} \mathrm{~W}$ ithin the group of servants, we can see a hierarchy. For example, the Indian servant in the further left corner in front of the bookshelf has a pin and sash around his turban, thereby symbolizing his supervisory role over the other Indian servants.

Additionally, the inclusion of a bookshelf, paintings on the wall, and American and British flags at the head of the table, indicate strategies associated with the YMCA's "environmental evangelism: the intentional manipulation of space to promote conversion." ${ }^{159}$ For example, the framed painting on the wall provides not just a decorative element but also an opportunity for the YMCA to inspire and motivate young men. The YMCA also hung notable prints, including Thomas Cole's The Cross and the World, which reads “on the path through the world, the other the often more difficult, but more rewarding, path of god." ${ }^{160}$ Although it is unclear which image or

\footnotetext{
${ }^{156}$ Brian Coe and Paul Gates. The Snapshot Photograph: The Rise of Popular Photography, 1888-1939. London: Ash \& Grant, 1977.Page 65.

${ }^{157}$ Carole Turbin. "Fashioning the American Man: The Arrow Collar Man, 1907-1931” in Gender \&History 14:3 ( November 2002) pages 470-491.

${ }^{158}$ Alison Blunt. "Imperial Geographies of Home: British Domesticity in India, 1865-1925" in Transactions of the Institute of British Geographers 24:4 (December 1999) pages 421-440.

${ }^{159}$ Paula Lupkin. Manhood Factories: YMCA Architecture and the Making of Modern Urban Culture. Minneapolis: University of Minnesota, 2006. Page 5-6.

${ }^{160}$ As cited in Ibid, page 66.
} 
print is contained within the frame in this photograph, the YMCA interior and exterior were carefully constructed spaces used dually as physical spaces and avenues to recruit into the YMCA.

Images of the interior and exterior spaces of YMCA buildings were published and sold by the YMCA in the early twentieth century. ${ }^{161}$ In her assessment of American YMCA postcards, Paula Lupkin asserts that "YMCAs were, for many, a symbol of the feminine 'home' in the big city, a refuge from vice, corruption, greed, and all that made the city modern and masculine.. ${ }^{162}$ At the same time, the YMCA building was part of a list of "architectural icons to British rule" used in Colonial Office Visual Instruction Committee (COVIC) lantern-slide project. ${ }^{163}$ The YMCA signified meaning for different groups, further illustrated by the American and British flags placed in front of Mr. Jessop. They highlight the ideological differences between British and American factions of the YMCA. The major difference between the American and British YMCA concerned the overall organization's relationship to India, which came to a head when Influential International YMCA Traveling Secretary Sherwood Eddy YMCA openly declared support for the Gandhi-led Indian National Congress in the 1920s. ${ }^{164}$

Brown's caption dates this photograph as 1910, the same year that the YMCA stopped publishing purity literature. Sex education was a facet of the YMCA's physical education program, serving the important moral function of making men better fathers and women better mothers. ${ }^{165}$ John Donald Gustav-Wrathall calls this the hetreosexualization of the YMCA, which began in the 1900 s, as noted above, as a response to anxiety over homosexuality; ${ }^{166}$ the homosocial nature of

\footnotetext{
${ }^{161}$ Ibid, page 104 .

${ }^{162}$ Ibid.

${ }^{163}$ James. R.Ryan. Picturing Empire: Photography and the Visualization of the British Empire. Chicago: University of Chicago,1998. Page 195.

${ }^{164}$ Ian Tyrell. Reforming the World: The Creation of America's Moral Empire. Princeton: Princeton University Press. Page 182.

${ }^{165}$ Ibid, page 32.

${ }^{166}$ John Donald Gustav-Wrathall. Take the Stranger by the Hand: Same-Sex Relations and the YMCA. Chicago: University of Chicago, 1998. Page 130.
} 
activities that involved admiration for and cultivation of ideal masculine bodies certainly exacerbated these anxieties. Increasingly, women were included in the YMCA, mainly as an extension of their conventional domestic roles, through auxiliary committees tasked with organizing dances or helping to decorate YMCA events. Most often, wives of YMCA secretaries, including Mrs. Jessop, would head women's auxiliary committees. Their role as the "ideal YMCA wife was to provide increased domestic service so as to facilitate the YMCA secretary's work and relationship with other men." ${ }^{167}$ Understood in this way, Mrs. Jessop’s inclusion at the dining table reinforces Mr. Jessop's role as the patriarchal figure who supervises and guides members such as Brown and his YMCA companions in the path of respectable masculinity.

The increasing role of women in the YMCA can be further seen in figure 17, which is captioned Tiffin at the Bot:Gdns 1910 Xmas Day. This image depicts a group having a light lunch (known as "tiffin" in India) popularly enjoyed by families because, unlike swimming, it was an integrated activity and often included children. Tiffin is thought to derive from the term "to tiff," or to take luncheon, the 1785 definition of eating and drinking out of meal time." ${ }^{168}$ In contrast to figure 16 , the men and women display a more relaxed body language as they are seated on a blanket facing the camera. The photographer has taken the image from the same lowered position as the subjects being photographed. This gives the impression that the photographer was part of the group; he is taking the image from within the group. As Brown does not appear to be in the image, he most likely could have taken the photograph. Although Brown has not associated the image with the YMCA through a caption, the same figures depicted at the YMCA Christmas table can be seen in this image.

\footnotetext{
${ }^{167}$ Ibid, page 101.

${ }^{168}$ Cecilia Leong-Salobir. Food Culture in Colonial Asia: A Taste of Empire. London: Routledge, 2011. Page 57.
} 
The Calcutta Botanical Garden was a popular space for leisure because it combined elements of "home" for the British. ${ }^{169}$ It appealed to expatriates, offering to visitors a controlled and protected environment to enjoy tropical Indian flora and fauna. ${ }^{170}$ At the same time, the Calcutta Botanical Garden was a carefully curated and cultivated space for horticulture, imposing a British sense of order on what was otherwise perceived to be an unruly Indian space. The Calcutta Botanical Garden can be understood, in short, as cultivating colonialism, remaking an Indian space as a pleasurable site for leisure activities of promenading and picnicking to be enjoyed by British expatriates. ${ }^{171}$ Understood in this way, Brown and his YMCA companions are recreating a "home experience" not only by choosing to be together on Christmas Day but also by engaging in popular leisure activities associated with the family, in this case, picnics at the Calcutta Botanical Garden.

The YMCA familial group is further reinforced as the Indian servants are visually relegated to the background. Moreover, they appear from a lowered camera angle, visually occupying the same spatial position as the trees and, like these trees, function as backdrop. Members of Brown's party are depicted wearing circular hats also known as sola topis, ${ }^{172}$ which according to Bernard S. Cohn are "the requisite for health of the white man in the tropics ... particularly in the sun of any strenuous physical exercise." ${ }^{173}$ This image was taken in December when the weather would have been cool enough that a protective hat may not be needed. In fact, not all of the sola topis depicted in the photograph are worn; some are placed on the ground. By adopting sola topis and having tiffin in the Botanical gardens, Brown and his YMCA family are conforming to socially acceptedand Indianized--forms of leisure acts that included women. This is in contrast to surf-bathing on

\footnotetext{
${ }^{169}$ Renamed in 2009 as Acharaya Jagadish Chandra Bose Botanical Garden.

${ }^{170}$ David Arnold. Science, Technology, and Medicine in Colonial India. New York: Cambridge University Press, 200. Page 52.

${ }^{171}$ Richard Axelby. "Calcutta Botanic Garden and the Colonial re-ordering of the Indian environment" in Archives of Natural History 35:1 (2008) page 153-156.

${ }^{172}$ Cloth covered helmet made of cork and pith from the sola, topi stands for hat in Hindi.

${ }^{173}$ Bernard S. Cohn. Colonialism and Its Forms of Knowledge: The British in India. Princeton: Princeton University Press, 1996. Page 155.
} 
the seashore at Puri, where women would not have been welcomed. By including women in social functions the YMCA could stress the appearance of a "normal” relationship, especially during a seemingly abnormal time when the European men greatly outnumbered European women in India. ${ }^{174}$ The colonial setting would have exacerbated the YMCA's concern over homosexuality. However, a social activity like a dance would warrant an even ratio of men to women. The number of men photographed in both figures 16 and 17, however, suggest that these recurring figures are not a random assemblage of YMCA members. Rather, they are a group that was cultivated and molded according to YMCA's conceptions of a fraternal family.

The fraternal nature of Brown's Christmas activities can be seen in figure 18, which is captioned Xmas Day 1919 @ the Chauncery ${ }^{175} 15$ Park Street in black handwriting below the photograph. This photograph shows a posed group of twelve men arranged in a semi-circular line facing the camera. In the first row, six men sit on wicker patio chairs. Brown is on the far left, behind them. Alongside Brown, the five other men form a line standing behind the men on chairs. The caption indicates that this image was taken in December, with the men's clothing reflecting the temperate climate of winter in India. However, as indicated by the caption, the use of "chauncery" suggests a government or diplomatic undertone. At the centre of Calcutta were colonial offices and the European quarters "with means to supply all European needs, consumer articles from Fortnum and Mason, ball nights, cricket clubs, and red light districts, a city within a city." ${ }^{176}$ Given the many colonial clubs offering tennis, Brown's use of “chauncery" suggests his aspiration to align himself to a position higher than his middle-class status. Membership to colonial clubs was not

\footnotetext{
${ }^{174}$ The total European population in India as late as in 1921 "comprised approximately 45,000 women and some 112,000 men" as cited in Mrinalini Sinha. "Britishness, Clubbability, and the Colonial Public Sphere” in Bodies in Contact: Rethinking Colonial Encounters in World History. Durham and London: Duke University Press, 2005. Edited by Antoinnette Burton and Tony Ballantyne. Page 185.

${ }^{175}$ The writing is difficult to read.

${ }^{176}$ Sudipta Kaviraj. “ Filth and the Public Sphere Concepts and Practices about Space in Calcutta” in Public Culture 10:1 ( 1997) page 87.
} 
extended to middle-class missionaries, but rather, as Mrinalini Sinha argues, these exclusive clubs "cultivated a particular type of whiteness which they reserved for elite European men."177

Moreover, not all of the men are named through captions, most notably the seated man third from the right. All of the men's names are written in black ink except for the gentlemen in the second row, third from the right that is captioned in a lighter ink, Boothryd. The exclusion of names and difference in the ink used to caption Boothrooyd suggests that Brown may not have known all of the men included in this group portrait. Brown was what Elizabeth Buettner describes as a "transient white," by dint of his middle-class status, as the son of a missionary who was sent to England to attend a school for the children of missionaries. ${ }^{178}$ Buettner argues that in imperial India physical appearance is not enough to connote whiteness: a more important attribute of whiteness is the type of schooling one received. ${ }^{179}$ Although Brown did not attend an elite public school in England, his education abroad nevertheless signified his whiteness and thereby differentiates him from the other lower-middle class men. By confirming to the YMCA configuration of manhood and gaining membership to the YMCA family, Brown further signifies his position as a white Christian middle-class male in fraternal affiliation with his fellow members.

\section{Conclusion}

The captions of all the photographs discussed here in this chapter indicate that they were taken before 1915. To become a member of the YMCA family, men like Brown also achieved manhood as defined by the institution, namely a white Christian version of this ideal. For Brown, this affiliation was reinforced through photography in that the YMCA conceptions of manhood

\footnotetext{
${ }^{177}$ Mrinalini Sinha. "Britishness, Clubbability, and the Colonial Public Sphere" in Bodies in Contact: Rethinking Colonial Encounters in World History. Durham and London: Duke University Press, 2005. Edited by Antoinnette Burton and Tony Ballantyne. Pages186-187.

${ }^{178}$ A particular group of middle-class that was marked by period of travel to and from the metropole which created a distinct middle-class. She explores this larger framework that supports this particular class through her study of schools for the children of missionaries. For more see Elizabeth Buettner. Empire Families: Britons and Late Imperial India. Oxford: Oxford University Press, 2004. Pages 170-200.

${ }^{179}$ Elizabeth Buettner. Empire Families: Britons and Late Imperial India. Oxford University Press, 2004. Page 3.
} 
and family intersect and are visually reinforced through personal photographs that are common to both the YMCA and Brown (and Archer's) personal albums. Brown and his companions position themselves in these posed portraits to the "familial gaze," which for them was part of a global Christian family, an "imagined community" of Christian brotherhood that transcended racial and class boundaries. Brown's posed portraits can be related to the wider practices of popular photograph, which, as Karen Strassler argues, extends beyond the personal domain and is inextricably tied to national and colonial histories. ${ }^{180}$ Their imagery operates on the basis of shared meaning. For Brown and his YMCA family, meaning was based on a shared conception of YMCA Christian manhood that drew upon conventions of leisure and family photography. The YMCA family is visualized through these "shared visual idioms" and practices in which...people come to belong to the community that calls itself." ${ }^{\text {181 }}$ In this case, the community was the YMCA family, an organization tied to a civilizational and colonial project. By conforming to the YMCA notion of manhood through his posed portraits, Brown confirmed his membership to the YMCA and in doing so reinforced the normative YMCA family as white, masculine, middle-class, and Christian. While Indian men entered the picture, they did so only by virtue of enabling white men to attain their ideal manhood. Indian women and children also entered the picture. In my next chapter, I consider their significance in relation to these ideals of white Christian masculinity and YMCA family.

\footnotetext{
${ }^{180}$ Karen Strassler. Refracted Visions: Popular Photography and National Modernity in Java. Durham and London: Duke University Press, 2010. Page 5.

${ }^{181}$ Ibid.
} 



\section{Chapter Two: Picturing Paternalism}

The YMCA's student offshoot, the Student Volunteer movement (SVM) believed that Christ would return to rule the millennium. ${ }^{182}$ Their call for the "Evangelization of the World in This Generation,” advocated, not conversion, but rather proclamation of the gospel to the world. ${ }^{183}$ In other words, SVM wanted all peoples to witness the gospel. ${ }^{184}$ As Gail Bedermen argues, in light of Darwin’s evolutionary theories, Protestant America had to reconfigure millennialism: "Instead of God working in history to perfect the world, believers in civilization described evolution working in history to perfect the world." ${ }^{\$ 85}$ This belief spread to the YMCA as evident when the SVM sent their first student secretary to India as a precursor to American YMCA involvement. Significantly, evangelical outreach unfolded through the "symbolism of a parent-child relationship," ${ }^{186}$ with an initially heavy dependence on the "parent," who is charged with guidance of the child until he or she is self-sufficient. ${ }^{187}$ This approach to outreach was based on the assumption of the Christian missionary's moral superiority.

It wouldn't be until the early 1910s that the YMCA began to adapt to an Indian context in the course of a fraught indigenizing process described in the previous chapter. ${ }^{188} \mathrm{By}$ the beginning of the twentieth century, the YMCA began to present Christianity through the lens of Hinduism in

\footnotetext{
${ }^{182}$ According to Revelation 20:1-7 this is the thousand-year period during which Christ would reign on earth, understood more colloquially as the second coming that marks the beginning of the millennium.

183 Dana L. Robert. "The Origin of the Student Volunteer Watchword: “ The Evangelization of the World in This Generation.” In International Bulletin of Missionary Research (1968) page 147.

${ }^{184}$ Ian Tyrrell. Reforming the World: The creation of America's Moral Empire. Princeton: Princeton University Press, 2010. Page 52.

${ }^{185}$ Gail Bederman. Manliness \& Civilization: A Cultural History of Gender and Race in the United States 1880-1917. Chicago: University of Chicago Press, 1995. Page 26.

${ }^{186}$ Emily S. Rosenberg. Spreading the American Dream: American Economic and Cultural Expansion,1890-1945. New York: Hill and Wang, 1982. Page 29.

${ }^{187}$ Emily S. Rosenberg. Spreading the American Dream: American Economic and Cultural Expansion,1890-1945. New York: Hill and Wang, 1982. Page 29.

${ }^{188}$ M.D David. The YMCA and the Making of Modern India: A Centenary History. New Delhi: National Association Press, 1992. Page 19.
} 
order to compete with Hindu revivalism and nationalism-all the while holding onto its sense of moral superiority. ${ }^{189}$ One strategy was through the publication of notable literary works such as $A$ Primer in Hinduism (1910) and The Crown Hinduism (1913) by YMCA National Secretary J.N. Farquhar..$^{190}$ J.N. Farquhar's signature appears, alongside that of Brown, in Mr. Jessop's autograph book (Fig.19). In 1912, Farquhar stated that, "god does not desire to iron out the human race flat to smooth out all national differences, to make men by the gross after a pattern." ${ }^{191}$ Accordingly, for YMCA members like Brown and Archer, a "Saturday Outing” may include visits to rural and urban missionary institutions; such social outings exposed men to local influences, an activity considered necessary to strengthen their moral fiber. Consider, for example, a report included in the Saturday, $1^{\text {st }}$ June 1912 edition of Central Branch Notes, which reads:

A party of fourteen went down to the L.M.S. Mission at Kaurapukur last Saturday and were delightfully entertained by the Rev. J.W. Morgan. The drive was a most interesting one and all were greatly pleased with the outing. Next Saturday we hope to have another such trip this time visiting one of the mission stations up the river. ${ }^{192}$

Such an outing provided an occasion for YMCA members to encounter Indian women and children in rural or mission institutions.

Just as importantly, this context would also provide picturesque subjects for YMCA members to indulge in their hobby of photography. Significantly, Brown's YMCA branch had a

\footnotetext{
${ }^{189}$ Kenneth Latourette. World Service: A History of the Foreign Work and World Service of the Young Men's Christian Association of the United States and Canada. New York: Association Press, 1957. Page 115.

190 Kenneth Latourette. World Service: A History of the Foreign Work and World Service of the Young Men's Christian Association of the United States and Canada. New York: Association Press, 1957. Page 115. M.D David. The YMCA and the Making of Modern India: A Centenary History. New Delhi: National Council of YMCAs of India, 1992. Page 30.

${ }^{191}$ As cited in Jennifer C. Snow. Protestant Missionaries. Asian Immigrants, and Ideologies of Race in America, 18501924. New York: Routledge, 2007. Page 49.

${ }^{192}$ Central branch Notes 1911-1913. Box 90. India Files. Y.USA.9-2-40. Kautz Family YMCA Archives. University of Minnesota.
} 
camera club amongst other activities like cycling, tennis and social evenings. ${ }^{193}$ Although little is known about the Calcutta Camera Club, ${ }^{194}$ such a club would not have been uncommon given the "largely European serious-amateur photographic community" in Calcutta. ${ }^{195}$ YMCA camera clubs served as a platform for young amateurs to pursue photography, some leading to professional careers, as was the case with Richard Avedon, who joined his local YMCA camera club in 1935 and used his sister as a model. ${ }^{196}$ Additionally, YMCA Camera Clubs served as a space for photographic exchange among elite members, as was the case with many amateur clubs. ${ }^{197}$ By contrast, the financial cost of photography made it inaccessible to many middle-class Indians and “poor whites," with even a secondhand pocket-folding Kodak costing as much as fifty rupees in 1915. ${ }^{198}$ Therefore, it is most likely that this camera club existed for the upper crust of YMCA membership.

While other amateur photographic communities like the Bengal Photographic Society included women on their membership lists as early as $1857,^{199}$ the YMCA camera club reserved membership exclusively to men. Under the supervision of a YMCA secretary such as Mr. Jessop, young men like Brown would have been mentored in photographic techniques and practices. The

\footnotetext{
${ }^{193}$ M.D David. The YMCA and the Making of Modern India: A Centenary History. New Delhi: National Association Press, 1992. Page 76.

${ }^{194}$ The only mention of this club is a brief mention as part of a larger list of activities specific to the Calcutta Cowringhee branch mentioned in M.D David. The YMCA and the Making of Modern India: A Centenary History. New Delhi: National Association Press, 1992. Page 76.

${ }^{195}$ Sudhir Mahadevan. A Very Old Machine: the Very Origins of Cinema in India. Buffalo: State University of New York, 2015. Page 35.

${ }^{196}$ James S. Baugess and Abbe Allen DeBolt (eds). Encyclopedia of the Sixties: A Decade of Culture and Counterculture. Santa Barbara: Greenwood, 2012. Page 43. The YMCA Camera Club is also briefly mentioned in James W. Martens. "Young Man! When you're low on your Dough: the Depression YMCA's leisure Time League. Alberta History 52:4 (2004). Pages 22-26.

${ }^{197}$ Grace Seiberling, Carolyn Bloore and the International Museum of Photography at George Eastman House. Amateurs, Photography, and the Mid-Victorian Imagination. Chicago: University of Chicago Press, 1986. Page 10.

${ }^{198}$ Ibid, page 38 .

${ }^{199}$ Debjani Sengupta. "Zenana Studio: Early Women Photographers of Bengal, from Taking Pictures: The Practice of Photography by Bengalis, by Siddhartha Ghosh” in Trans Asia Photography Review 4:2 (Spring 2014) page 2.
} 
programming of each YMCA location reflects the needs of its membership, ${ }^{200}$ with the Calcutta Central branch arguably more inclined to the arts, as evident in a note for Saturday $25^{\text {th }}$ March 1911, which reads:

Next lecture in this series is on April $8^{\text {th }}$ and will be given by the Chairman of our Committee of Management, Mr. Percy Brown. The subject is "Old Brasses" and will be illustrated by a set of specially prepared slides as well as by a collection of some choice specimens of old brass. ${ }^{201}$

As the principal of the Government College of Art \& Craft in Calcutta from 1909 until 1927, Percy Brown was also the chairman of the Committee of Management while Brown was a member. Percy Brown's signature also appears in Mr. Jessop's autograph book (Fig. 20). This is an important artistic connection that is directly tied to the Calcutta YMCA Central Cowringhee branch, and without a doubt would have had an impact on Brown's YMCA experience and his knowledge of Indian art and architecture. The latter is reflected in Brown's album where captions like carving on Nepalese temple, and stone carving are used.

Although it is not known whether Brown and his YMCA companions were part of this club, we can observe stylistic influences common among amateur photographers of the period in images included in Archer and Brown's albums. Specifically, such clubs were places where members enthusiastically embraced the techniques and styles associated with pictorialism, a movement that emerged in the 1880s and remained popular until the end of the Second World War, and which emphasized the artistic qualities of photographs. ${ }^{202}$ Brown's album and those of

\footnotetext{
${ }^{200}$ Mayer N. Zald. Organizational Change: the Political Economy of the YMCA. Chicago: University of Chicago Press, 1970. Page 48.

${ }^{201}$ Central branch Notes 1911-1913. Box 90. India Files. Y.USA.9-2-40. Kautz Family YMCA Archives. University of Minnesota.

${ }^{202}$ For more on pictorialist amateur clubs see Rachel Sailor “'You Must Be Dreamy': Complicating Japanese-American pictorialism and the Early Twentieth-Century Regional West” in European Journal of American Studies 9:3 (2014) Also see Grace Seiberling, Carolyn Bloore and George Eastman House. Amateurs, Photography, and the MidVictorian Imagination. Chicago: University of Chicago Press, 1986.
} 
his fellow YMCA members feature numerous pictorialist photographs that emphasized the artistic qualities of Indian women and children, many of whom are described using the racializing term “gypsy." ${ }^{203}$

This chapter examines the significance of the inclusion of these exoticized subjects-who would not have been considered members of the men's families-and explains how the appearance of these subjects in the men's albums complicates the YMCA's familial discourse. The extensive overlap between Brown and Archer's images-copies of the same images of Indian women and children appear in their albums-suggests that the YMCA played a role in facilitating the photographic style, content, and imagery common among its members by providing opportunities for photographing Indian women and children. What does the crossover of imagery-by which I mean the replication of the same images or types of images-in Brown and Archer's albums reveal about how these two men "look" at Indian women and children?

Focusing on the pictorialist depiction of Indian women and children, who are prominently featured in the albums, I will demonstrate that the crossover in imagery illustrates the YMCA's paternalistic relationship with respect to these exoticized subjects. Starting with a close reading of an image of three Indian school girls captioned The Three Graces (Fig. 21) from Brown's album, alongside an image captioned “We are Seven” (Fig. 22) from Archer's album. Next, I turn to a photograph of a young Indian girl with a child captioned Enjoying it in Brown's album (Fig. 23), an image that is visually echoed on page 18 from Archer's album (Fig. 24), which is captioned $A$ ‘Brown' Study (Gipsy). By employing pictorialist techniques, Brown and Archer take part in

\footnotetext{
${ }^{203}$ For Archer's album, images of Indian women and children occupy the highest count in terms of the subject of the mages present in the album. For Brown's album Indian women and children come second after photographs of temples in terms of quantity.
} 
overlapping rituals, including photographic looking (and collecting) and fraternal bonding as an important means of developing group solidarity. ${ }^{204}$

\section{$\underline{\text { Pictorialist Parents }}$}

A photograph on a loose page associated with Brown's album (Fig.21) contains an image captioned The Three Graces and depicts three Indian schoolgirls standing in linear order on three flights of stairs. Another photograph from Archer's album shows seven young Indian children sitting in a row captioned "We are Seven" (Fig.22). Intriguingly, Archer's caption references a poem by William Wordsworth, also titled "We are Seven," which was published in Lyrical Ballads (1798). Although Brown does not explicitly acknowledge Wordsworth as his influence, nevertheless the Romantic ideals espoused in Wordsworth's work are manifest visually in the photograph.

Brown's photograph (Fig.21) depicts three Indian child pose standing on a stair; they are lined up shoulder to shoulder in descending order based on height. The shortest child on the lowest step is pictured on the right of the image, her hands are crossed together and she is looking at the camera. The child in the middle has her arms by her side, and also looks at the camera. The tallest child is at the top step, with her arms likewise by her side, but looking to the side of rather than directly at the camera. All three Indian children wear clothes of similar style, the most notable characteristic of which is their variation of puffy sleeved blouses. Cloth has been draped and has been either held together by a belt or tucked in the case of the child in the middle by a pin,

\footnotetext{
${ }^{204}$ Dana D. Neslon. National Manhood; Capitalist Citizenship and the Imagined Fraternity of White Men. Durham and London: Duke University Press, 1998. Pages 203. Newlson is drawing on the foundational work of Mary Ann Clawson and Benedict Anderson. For more on the rituals of brotherhood and fraternal bonding see Mark C. Carnes, "Middle-Class men and the Solace of Fraternal Ritual" in Meanings of Manhood: Constructions of Masculinity in Victorian America. Edited by Mark C. Carnes and Clyde Griffin. Chicago: University of Chicago, 1990. Also Judith Newton. From Panthers to Promise Keepers: Rethinking the Men’s Movement. Lanham, Maryland: Rowman \& Littlefield Publishers, 2005. Pages 27-51.
} 
thereby giving the impression of $s a r i .^{205}$ But this is by no means a conventional sari, but rather resembles a classically draped toga. By contrast, the everyday attire of elementary schoolchildren would have been a simpler sari, which would not have required a belt to fasten as was the case with schoolgirls in the photograph, suggesting that their costumes were fashioned for the camera.

Each girl is adorned with a headpiece, alongside a multitude of bracelets and earrings. The tallest child wears what appears to be a brooch on her right shoulder, further emphasizing that a great deal of thought went into crafting this image. The impact of the jewelry and clothing suggests that these children are posed in a manner that suggested adulthood, for they wear clothing and jewelry associated with older women. Within the confines of classical Greek mythology, the “Three Graces” personify charm, grace and beauty. Elizabeth Edwards states that the:

The 'romantic' mode ...is linked to a strongly aesthetic response and to notions of the exotic...Pose is also used in this way. For example, the oppositional connotation of three young women posed in the western iconographical convention of "Three Graces" in the mode of Botticelli. ${ }^{206}$

Brown's image does not explicitly draw on the Botticelli inclined “Three Graces," where the fertility and beauty of the young women are emphasized, though the drapery does gesture toward a classical Roman and not just Indian style of dress. Instead, as noted above, Brown's reference to the "Three Graces" links directly to Wordsworth's poem, entitled "The Triad”: Come, like the Graces, hand in hand!'/ For Ye, Though not by birth allied/ Are sisters in the bond of love.”207 The poem was published in The Keepsake, an illustrated collection of poetry and prose sold from 1828 to 1857 during the holiday season. ${ }^{208}$ In the poem, Wordsworth describes three idealized

\footnotetext{
${ }^{205}$ A garment measuring five to nine yards by two to four feet reserved for females that is wrapped around the body. ${ }^{206}$ Elizabeth Edwards. "Introductory Essays" in Photography and Anthropology: 1860-1920. Edited by Elizabeth Edwards. New Haven and London: Yale University Press and The Royal Anthropological Institute London, 1992. Page 9.

${ }^{207}$ Wordsworth, William. The Complete Poetical Works. London: Macmillan and Co., 1888; Bartleby.com 1999. Lines 16-18 www.bartleby.com/145/

${ }^{208}$ "Introduction to The Keepsake" Romantic Circles Accessed at https://www.rc.umd.edu/editions/lel/ksintro.htm\#1
} 
women whom the poet presents to an imagined suitor. Wordsworth identified the women as Edith Southey, Dora Wordsworth and Sara Coleridge. ${ }^{209}$ By invoking these women in his poem, Judith W. Page contends, Wordsworth asserted the role of a pater familias, in the role of matchmaker who imposed a male perspective in constructing ideal femininity. ${ }^{210}$ By referring to the schoolchildren as the "Three Graces," then, Brown visualized the three girls through a familiar visual trope and through a literary convention that espoused paternalism. By posing and dressing up these children, Brown further objectifies these girls as props in his own artistic interpretation of "The Three Graces" and "The Triad.”

By the early nineteenth century, as Griselda Pollock notes, the canonical conventions the “Three Graces” came to embody a "specific image of femininity where grace becomes a 'naturalized' attribute." ${ }^{211}$ Yet, for Protestant evangelicals the concept of grace not only entailed the love and mercy of god but was also part of the salvation of one's soul. ${ }^{212}$ Within the YMCA framework, grace and conversion went hand in hand. It was through friendship, however, that God's grace would be realized by the convert. ${ }^{213}$ When it comes to this photograph, the schoolgirls depicted do not fall in either of these categories as emblems of idealized womanhood or potential members of the YMCA family. Instead, they function as artistic props.

Archer's photograph is similarly composed. It features seven young Indian girls seated in a row captioned “We are Seven.” This photograph appears on page 18 of his souvenir album, which he prepared for Mrs. Jessop (Fig.22). Like Brown's photographs, the children are seated in

\footnotetext{
${ }^{209}$ Derek Furr. “The Perfect Match: Wordsworth's 'The Triad' and Coleridge's ' The Garden of Bocccacio” in Romantic Texualities: Literature and Print Culture, 1780-1840 ( Winter 2005) page 51.

${ }^{210}$ Judith W. Page. Wordsworth and the Cultivation of Women. Berkeley: University of California Press, 1994.Page 131.

${ }^{211}$ Ibid, page 1888 Griselda Pollack. "The Grace of Time: Narrativity, Sexuality, and a Visual Encounter in the Virtual Feminist Museum” in Art History 26:2 ( April 2003) pages 1888.

212 Marilyn J. Westerkamp. "Female Leadership roles in American Awakenings, 1730-1830" in The Rise of the Laity in Evangelical Protestantism. Edited by Deryck Lovegrove. London: Routledge, 2003. Page 95.

213 John Donald-Gustav Wrathall. Take the Stranger by the Hand: Same-Sex relations and the YMCA. Chicago: University of Chicago, 1998. Page 46-49.
} 
a line arranged based on height and sartorial attire. The two girls at the end of the line are draped in white cloth and are standing while the rest of the five girls are seated on a bench. The girls on the bench are seated in a way that visually balances the composition of the image. For example, the checkered cloth worn by the two girls is balanced by the weight of girl in the center of the bench, who is arguably much taller and perhaps older than the rest of the girls in the photograph.

As noted above, "We are Seven" invokes Wordsworth's poem from Lyrical Ballads (1798). In this poem, Wordsworth addresses a "little cottage girl," asking her how many siblings she lives with and trying to correct the child's belief that her dead siblings live with her. ${ }^{214}$ Like the children depicted in the image, Wordsworth's poem depicts the children as "eight years old, she said:/ her hair thick with many a curl/ that clustered round her head." ${ }^{215}$ Each Indian child's hair in the photograph has been parted in the middle and glistens with the reflection of the sun's rays.

Notably, the YMCA members shared with the Romantics the notion that childhood depended on Christian nurturing, a belief heavily influenced by Horace Bushnell's insistence that, "a child is to grow up a Christian, and never know himself as being otherwise. ${ }^{216}$ Part of this conception was also informed by G. Stanley Hall's recapitulation theory, ${ }^{217}$ wherein children develop in relation to their ancestry and accordingly are placed in a scale according to a phases of evolution based on the development of the human race from savagery to civilization. ${ }^{218}$ This view, however, did not apply equally to boys and girls, with the latter being understood as inherently different. According to Hall, girls were sentimental, tame, and tractable, unlike boys which were

\footnotetext{
${ }^{214}$ William Wordsworth. The Complete Poetical Works. London: Macmillan and Co., 1888; Bartleby.com, 1999. www.bartleby.com/145/

${ }^{215}$ Ibid.

${ }^{216}$ David M.Macleod. Building Character in the American Boy: The Boy Scouts, YMCA and Their Forerunners, 1870-1920. Madison: University of Wisconsin Press, 1983. Page 23.

217 A professor of Pedagogy and Psychology, most well known for recapitulation theory, the play movement, and his formulations to combat Neurasthenia.

${ }^{218}$ Ibid, page 99
} 
closer in development to primitive man. ${ }^{219}$ Indian schoolgirls, such as the ones depicted here, with their purportedly sentimental and easily controllable nature-according to this concept of Christian nurturing-made them a favourite subject for pictorialist study, an art form characterized by soft focus and associated with allegory and celebrations of nature, features that were considered “feminine." ${ }^{220}$ Recapitulation theory, a belief that expounded on romantic ideals, explains the motivation for a composition of this kind, and accounts for why girls rather than boys would be featured as photographic subjects for men like Brown and Archer. At the same time, this preponderance of female subjects is all the more significant when we consider the YMCA's fraternal focus. How, then does looking at Indian girls help bolster the male photographer's sense of masculinity?

The child described in "We are Seven" is described as a "simple child," who is so naïve that he asks "What should it know of death?" ${ }^{221}$ Wordsworth emphasizes the child's simple nature by depicting her inability to comprehend that she is part of a group of five because two siblings have passed away. ${ }^{222}$ The child, in turn, respects the author's authority through salutations such as "Sir" or "O Master!" ${ }^{223}$ By the end of the prolonged exchange, both the narrator and child are frustrated due to the lack of understanding and the last couplet reads "The Little Maid would have her will/ And said, "Nay, we are seven!" ${ }^{24}$ This last sentence is important because it expresses the child's refusal of the narrator's point of view.

\footnotetext{
219 Ibid.

${ }^{220}$ Colin Eisler “Going Straight: Camera Work as Men’s Work in the Gendering of American Photography, 19001923 ” in Genders 30 ) 1999 accessed online at https://www.atria.nl/ezines/IAV_606661/IAV_606661_2010_51/g30_eisler.txt

${ }^{221}$ William Wordsworth. The Complete Poetical Works. London: Macmillan and Co., 1888; Bartleby.com, 1999. Line 1 Accessed online at http://www.bartleby.com/145/ww124.html

${ }^{222}$ Linda M. Austin. "Children of Childhood: Nostalgia and the Romantic Legacy" in Studies in Romanticism 42:1 (Spring 2003) page 54.

${ }^{223}$ William Wordsworth. The Complete Poetical Works. London: Macmillan and Co., 1888; Bartleby.com, 1999. Line 45 and 64. Accessed online at http://www.bartleby.com/145/ww124.html

${ }^{224}$ Ibid.
} 
Similarly, in Figure 21, the photograph visualizes this balance, thematized in Wordsworth's poem, between respect and noncompliance through its depiction of the girls' body language. The three girls are posed in a symmetrical formation so much so that the each of their left shoulder showcases their matching frilly blouses. The posture and formation gives visual confirmation of compliance; the children have been arranged according to the YMCA's pictorialist sensibilities. Yet, each child expresses a slightly different response to the YMCA paternalistic gaze. For example, the child on the highest step looks to the side while her counterparts look towards the camera. Even while looking at the camera, the child in the middle has a furrowed brow, perhaps a sign of her chafing over the need to follow Brown's directions.

During this time, similarly dressed and posed images of Indian schoolgirls were also published in Johnson \& Henderson's Indian Amateur's Photographic Album ${ }^{225}$ (1856-1858) and William Henderson's The Oriental Races and Tribes, Residents and Visitors of Bombay: A Series of Photographs with Letter-Press Descriptions published in $1863 .{ }^{226}$ What is essential to note is that in the Indian Amateur's Photographic Album ( Fig.25), the Indian schoolgirls are introduced through the letterpress, followed by a lengthy discussion of their family background as "highly exemplary, and much to be commended, especially in a country in which, even among the higher classes of natives, it is so rare." ${ }^{227}$ A signifier of their respectable background is their education at the Mission-house at Ambrolie run by the Church of Scotland. It isn’t clear whether the missionhouse served as a photographic location, but what is crucial is that schoolgirls attending missionary institutions were photographic subjects for amateur photographers prior to Brown and Archer

\footnotetext{
${ }^{225}$ William Wordsworth. The Complete Poetical Works. London: Macmillan and Co., 1888; Bartleby.com, 1999. Line 1 Accessed online at http://www.bartleby.com/145/ww124.html

${ }^{226}$ Christopher Pinney. The Coming of Photography in India. London: The British Library, 2008. Page 118.

${ }^{227}$ As cited in the letterpress in Christopher Pinney. The Coming of Photography in India. London: The British Library, 2008. Page 118.
} 
taking these photographs. In this manner, Brown and Archer take up a practice that had already been well established.

Both figures 21 and 22 exemplify a paternalistic gaze through evoking the persona of a "simple child," as described in Wordsworth's poetry and through a stylized composition that reference artistic tropes like “The Three Graces.” By referencing Wordsworth, moreover, the photographs in the albums of Brown and Archer visually compose a paternal relationship. These images emphasized the ways that the YMCA's paternalism overlapped with romantic ideologies concerning childhood.

\section{$\underline{\text { Romantic Renderings }}$}

Archer's album opens with his dedication to Mrs. Jessop accompanied by a photograph of an Indian woman titled Contentment: ('A Wandering Gipsy-I') (Fig.26).The young girl squats on the grass and holds a hookah (tobacco pipe), with the tube portion held near her mouth in a way to suggest that she is smoking it. ${ }^{228}$ The girl is photographed outdoors, crouching barefoot amidst a vast array of vegetation, including what appears to be a potted plant that resembles a palm tree. Tropical vegetation and outdoor locations were often used as backdrops for images of "exotic women." ${ }^{229}$ This convention was so important that either a painted backdrop was used to give an impression of the tropics or an outdoor location was used. ${ }^{230}$

Archer does not name the subject of this photograph; rather, he uses a caption to generalize the individual as "Wandering Gipsy," in a manner that evokes anthropological studies depicting Indian castes and occupations. Indeed, as Deborah Epstein Nord observes, gypsy is a

\footnotetext{
${ }^{228}$ A smoking pipe that uses a long tube for inhalation. Originating from the Arabic hukka meaing casket/jar.

${ }^{229}$ James R. Ryan. Picturing Empire: Photography and the Visualization of the British Empire. Chicago: University of Chicago Press, 1998. Page 53.

${ }^{229}$ Ibid

${ }^{230}$ Ibid
} 
pejorative term that "referred to [a group of nomadic peoples] as a race, then as they invariably were, the epithet implied a number of characteristic-from dark skin, foreign origin, and inherent inferiority to common ancestry, culture, experiences and sensibility...just as it could convey bigotry, revulsion, and certainly disavowal." ${ }^{231}$ Therefore, "gypsy" had varied associations that were, more often than not, negative. ${ }^{232}$ By stylizing Indian women and labeling them as "gypsy," Archer references the nineteenth century belief that the origin of the Romani people was in India. ${ }^{233}$ The most popular comparison was between the Jat community in India and the Romani in England. ${ }^{234}$ Part of this conception of the "gypsy" rests on the idea of a culture existing outside history, as Katie Trumpener observes, "the Gypsies were a people who insisted, inexplicably on remaining in 'nature' rather than entering 'history'. ${ }^{235}$ It is for this reason that they are most often associated as a pastoral figure associated with the picturesque and served as a symbol of a preindustrial age during the eighteenth and nineteenth century. ${ }^{236}$ Yet at the same time, social reformers targeted them through specific bills such as the Vagrancy Act (1824), by penalizing anyone wandering or lodging under any tent or cart. ${ }^{237}$

Archer's use of "I" in his caption indicates that this image is part of a series. In fact, his album contains two other instances where Archer did not name the subject of the photograph;

\footnotetext{
${ }^{231}$ Deborah Epstein Nord. Gypsies \& the British Imagination, 1807-1930. New York: Columbia University Press,2006. Page 20.

${ }^{232}$ Nord is referencing the popular conceptions associated with "gypsy" at the time, the most popular being romantic.

${ }^{233}$ Although homogenizing, I use "Romani" here to refer to a group of people with a shared ancestry that have traveled together. I use this because the origin and dates of the Romani people are debated. I use this instead of "gypsy" to create a distinction between the captions and my own analysis. The term "gypsy" is not a self-designation, hence my weariness towards it. Also see George K. Behlmer. "The Gypsy Problem in Victorian England” in Victorian Studies 28:2 (January 1985) page 241.

${ }^{234}$ Ibid, page 242.

${ }^{235}$ Katie Trumpener. "The Time of the Gypsies: A "People without History" in the Narratives of the West" in Critical Inquiry 18 ( Summer 1992) Page 865.

${ }^{236}$ Deborah Epstein Nord. Gypsies \& the British Imagination, 1807-1930. New York: Columbia University Press,2006. Page 6.

${ }^{237}$ This one of many many bills where the state has specifically targeted Romani people for more see David Mayall. Gypsy-Travellers in Nineteenth-Century Society. Cambridge: Cambridge University Press, 1988. Page 190. Also see George K. Behlmer. "The Gypsy Problem in Victorian England” in Victorian Studies 28:2 (January 1985) pages 244253.
} 
rather he used a caption, again, to describe the individual as "gypsy." The generalization of captions and staged scenes functioned to reduce the individuals depicted in the photographs to a “type." This process was enabled through the invocation of anthropological conventions of the exoticizing ethnographic gaze and the artistic qualities of pictorialism. ${ }^{238}$ The caption "Wandering Gypsy" functions, then, in this typological way, associating the three characteristics of the caption: “contentment," "wandering," and "gypsy” with the staged scene, which include props such as the hookah, outdoor background, and pose to strengthen the artistic conventions of this image.

Figure 23 is a close-up image, captioned Enjoying it, which depicts a young Indian girl holding a child while breastfeeding. The young Indian girl confronts the camera by looking directly at it. The photograph's $4 \times 6$ inch size suggests that Brown used a folding Kodak camera. Photographers using this camera generally took pictures at chest level with a horizontal viewfinder on top of the camera. ${ }^{239}$ The camera angle of this image indicates a physical proximity between the photographer and subject. Tina Campt asks, in her analysis of an orphaned portrait of a woman, "how should we situate this girl's penetrating look in relation to the structures of domination the gaze so often signifies?"240 Although Campt is primarily concerned with the racial construction of the black diaspora, her question resonates in this context also, where there is a racial and gendered notion of power imbalance between looking and being looked at, where there is a distinction between a "gaze" rather than "the gaze." Whereas the concept of the gaze implies that the operator wields absolute control, the concept of a gaze allows for the possibility of an alternative reading by

\footnotetext{
${ }^{238}$ See Elizabeth Edwards (ed) Photography and Anthropology: 1860-1920. Edited by Elizabeth Edwards. New Haven and London: Yale University Press and the Royal Anthropological Institute, 1992. Also see Christopher Pinney. Photography and Anthropology. London: Reaktion Books, 2011.

${ }^{239}$ Jean Claude Gautrand. "Photography on the Spur of the Moment" in A New History of Photography Edited by Michel Frizot. Köln:Könemann, 1998.

${ }^{240}$ Tina Campt. Image Matters: Archive, Photography, and the African Diaspora in Europe. Durham and London, 2012. Pages 5-7, and 79.
} 
the "other." ${ }^{241}$ The woman who is the focus of Enjoying It can be seen as satisfying the prurient curiosity of her white spectators-and as challenging white bourgeois standards of self-restraint. ${ }^{242}$

At the same time, the circumstances under which this image was created may not reflect the compliance suggested by the women actively engaging with the camera. For Christian missionaries, the public exposure of Indian breasts in public had a controversial history, exemplified by the "breast-cloth controversies" in Southern Travancore during the 1820s, during which missionaries urged Nadar women to cover their breasts with cloth as a step towards a proper Christian life. ${ }^{213}$ Covering the breast in public was a sign of modesty and respectable modern femininity. ${ }^{24}$ YMCA members almost certainly would have held this Christian prejudice. This is not to suggest that the British imagination did not include imagery of breastfeeding, however; in the early twentieth century wet-nursing occupied a humorous niche in caricatures, which often satirized the absurdity of breast feeding in lieu of modern alternatives like hygienic bottles. ${ }^{245}$ And yet, the exposure of Indian breasts signified a Christian prudery tied to the belief that modest clothing was a requirement for respectability. Given this belief, it may be strange that such an image should appear in the YMCA photographs.

We can nevertheless account for this appearance when we consider the pictorialist leanings of YMCA members. Notably, pictorialists rarely considered the nude as offensive, particularly if

${ }^{241}$ Campt is drawing on bell hooks' conception of "a gaze”, for more see Tina Campt. Image Matters: Archive, Photography, and the African Diaspora in Europe. Durham and London, 2012. Page 80.

242 Stewart Dearing. "painting the other within: Gypsies according to the Bohemian Artist in the Nineteenth and early Twentieth Centuries” in Romani Studies 20:2 (2010) page 178.

${ }^{243}$ Nadars were previously known as Shanars, for more see Robert L. Hardgrave Jr. " The Breast-Cloth Controvery: Caste Consciousness and Social Change in Southern Travancore” in The Indian Economic \& Social History Review 5:2 (1968) pages 171-187. Also see Eliza Kent. Converting Women: Gender and Protestant Christianity in Colonial South India. Oxford: Oxford University Press, 2004. Page 5-7.

${ }^{24}$ Eliza Kent. Converting Women: Gender and Protestant Christianity in Colonial South India. Oxford: Oxford University Press, 2004.Page 221.

245 Linda Nochlin. "Morisot's Wet Nurse: The Construction of Work and Leisure in Impressionist Painting" in The Expanding Discourse: Feminism and Art History. Edited by Norma Broude and Mary D. Garrad. Page 237. 
"landscape [was used] for a background with no trace of recent habitation." ${ }^{246}$ The pictorialist rationalized the nude as an acceptable subject of photography by associating this figure with romantic ideals of untainted nature. Brown's image accords with this convention, for not only is it taken outside, but also traces of human impact are diminished by dint of the unfocused background. By 1910, such instruments as the Struss lens were available so that photographers could achieve a soft-focus effect. These became known as the "pictorial lens," so that resulting images had the appearance of being on a single plane. ${ }^{247}$ The style of this photograph clearly accords with the pictorial lens. In this way, a pictorialist sensibility enabled the YMCA amateur photographer to reconcile the contradiction between, on the one hand, his moral disdain of public nudity, and, on the other hand, his aesthetic appreciation of the nude.

Images of poor women breastfeeding in public from Egypt and North Africa were popular subjects for colonial photographers because of the irony the photographed women invoked through the simultaneous covering and uncovering of their bodies, ${ }^{248}$ much in the same way the body of the woman here is covered by her clothing except for her exposed right breast. The male fascination with the breasts of Indian wet-nurses was also a subject of medical journals. ${ }^{249}$ Therefore, Brown's male gaze must not be divorced from the image; instead the caption "Enjoying $i t$ " is certainly reflective of the erotic pleasure in reveling in the public spectacle of a young nude woman, which could be justified through the aesthetic preference of pictorialism. The subject of

\footnotetext{
${ }^{246}$ Gleeson White." The Nude in Photography” in A Photographic Vision: Pictorial Photography, 1889-1923 Edited by Peter C. Bunnell. Salt Lake City: Peregrine Smith Inc,1980. Page 81.

${ }^{247}$ Peter Bunnell. "Towards New Photography: Renewals of Pictorialism” in A New History of Photography Edited by Michel Frizot. Köln : Könemann, 1998. Page 316. For more on soft-focus lens see Christian A. Peterson. After the Photo-Secession: American Pictorial Photography, 1910-1955. Minneapolis: The Minneapolis Institute of Arts, 1997. Page 25-28.

248 Basuli Deb. "Cutting across Imperial Feminism toward Transnational Feminist Solidarities" in Meridians: Feminism, Race, Transnationalism 13:2 ( 2016) page 166.

249 Indrani Sen. "Colonial Domesticities, Contentious Interactions: Ayahs, Wet-nurses and Memsahibs in Colonial India: in Indian Journal of Gender Studies 16:3 (September 2009) page 323-325.
} 
the photograph might have defied Christian prudery, but Brown's gaze neutralizes the challenge she posed, submitting her display to his visual pleasure.

A similarly composed portrait of an Indian women and child appears in Archer's album (Fig.24). The girl depicted wears a bandana, embroidered clothing, and is adorned with jewelry. Even the infant wears a hat adorned with coins almost identical to figure 23 from Brown's album. Coin necklaces serve both a decorative and economic purpose, particularly for poorer women because these adornments ensured financial security. ${ }^{250}$ The woman depicted here wears a necklace of this type, which is double-tiered, further implying that this necklace would have brought her cultural and economic clout. Alternatively, according to Judith R. Walkovitz, within the British imagination Indian women who were portrayed laden with jewelry became a stereotype of Indian femininity known as "the nautch girl," or professional courtesan, whose role included dancing and entertaining. ${ }^{251}$ At the same time, Archer's caption visually illustrates what David Mayall describes as the "'classic' portrait of the Romany Gypsy: dark haired, black-eyed, dark complexioned and wearing a headscarf and large ornamental earrings." ${ }^{252}$ The association with dark complexion is part of a larger construct of beauty ideals that were shaped by literary tropes that positioned "the fair woman as the heroine and the dark one as the sensual or, in Victorian terms, fallen women," according to Inderpal Grewal. ${ }^{253}$ Therefore, Archer's use of quotation marks in the caption $A$ 'Brown' Study (Gipsy) suggests that this image is not referencing skin colour rather it is most likely a stylistic reference or credit to Cyril J. Brown. When viewed from this perspective, the adorned women in Brown's photograph signifies disreputability.

\footnotetext{
${ }^{250}$ Oppi Untracht. Traditional Jewelry of India. New York: Harry N. Abrams Inc, 1997. Page 278.

${ }^{251}$ Judith R. Walkovitz. "The Indian Woman: the Flower Girl, and the Jew: Photojournalism in Edwardian London” in Victorian Studies 42:1 (Autumn 1998-Autumn 1999) page 11. Also see Sara Suleri. The Rhetoric of English India. Chicago: University of Chicago Press, 1992. Chicago: University of Chicago Press, 1992. Page 92.

${ }^{252}$ David Mayall. Gypsy-Travellers in Nineteenth Century Society. Cambridge: Cambridge University Press, 1988. Page 83.

${ }^{253}$ Inderpal Grewal. Home and the Harem: Nation, Gender, Empire and the Cultures of Travel. Durham and London: Duke University Press, 1996. Page 207.
} 
Brown and Archer's imagery is related to official YMCA publications which depict Indian femininity, as seen in the YMCA publication India Awakening (1911) written by International Secretary Sherwood Eddy (Fig.26). This publication features a photograph captioned "dancing girl," which is juxtaposed next to an image captioned "low caste woman." Under the heading of "Womanhood," Eddy writes that "the condition of women is the truest test of the people's civilization. Her status is her country's barometer." ${ }^{254}$ What did these images mean for protestant evangelicals like the YMCA? Jennifer C. Snow contends that "Eddy's 1911 book, for instance, included photos of naked famine victims stacked in funeral pyre, 'child marriage,' a 'devotee' in a large iron collar, and a 'dancing girl." ${ }^{955}$ The choice to include such images over others suggested that American protestant evangelists “consistently chose disturbing ones." ${ }^{256}$ Such texts were instrumental because they were used as study manuals complete with discussion questions at the back. India Awakening would certainly have been part of Brown and Archer's visual and theological understanding of India, and their moral opprobrium in response to women, whom they perceived as disreputable but whom they nevertheless felt compelled to look at-and whom a colonial system was particularly determined to rescue and modernize.

At the same time, the trope of "gypsy" as visually depicted in figures 23 and 24 ran in parallel with the criminalization of the poor in India, where "economically marginalized or reputedly lawless groups, from hunter-gathers and displaces pastoralist to hawkers and 'gipsies,' were brought under the Criminal Tribes Act." ${ }^{957}$ Passed in 1871, this Act defined particular social and ethnic communities as habitually criminal. Although, the YMCA did not explicitly have

\footnotetext{
${ }^{25}$ Sherwood Eddy. India Awakening. New York: Missionary Education Movement of the United States and Canada, 1911. Page 139.

${ }^{255}$ Jennifer C. Snow. Protestant Missionaries. Asian Immigrants, and Ideologies of Race in America, 1850-1924. New York: Routledge, 2007. Page 130.

${ }^{256}$ Ibid.

${ }^{257}$ David Arnold. "The Medicalization of Poverty in Colonial India” in Historical Research 85:229 (August 2012) page 493.
} 
programming targeted towards "criminal tribes," it did engage in outreach work with the poor, which was usually carried out my missionaries or voluntary organizations. ${ }^{258}$ In fact, Brown's album contains a group of four photographs which depict outreach work and use captions such as handing out rice to the poor, waiting to be fed, or feeding the poor. The interest in evangelical outreach among the poor, coupled with their artistic potential certainly accounts for how often stylized Indian women and children appear in Brown and Archer's albums.

\section{$\underline{\text { Conclusion }}$}

When we look closely at the types of photographs common to both Brown and Archer's albums, we can discern the ways that Brown and his YMCA companions visualized Indian women and children paternalistically. Yet, these YMCA members' images of Indian women and children reduce the photographic subjects to artistic props that were supervised, posed, and unnamed. The crossover in imagery and photographic references between Brown and Archer's album indicate the use of "shared visual idioms" ${ }^{259}$ that conformed to the artistic and ideological conventions of pictorialism, romanticism, and imperialism. ${ }^{260}$ The convention of crediting another photographer's artistic composition is reflected in another pictorially inclined photograph ( Fig.28) from Brown’s album. The caption C.P Last occupies the position usually reserved for an artist's signature. Coincidentally, the surname Last is also associated with a person in the group portrait in figure 18.

In this sense, Brown and his YMCA network of photography functioned much like pictorial

\footnotetext{
${ }^{258}$ Ibid, page 500 .

${ }^{259}$ Karen Strassler. Refracted Visions: Popular Photography and National Modernity. Durham and London: Duke University Press, 2010. Page 5.

${ }^{260}$ For more on the tropes of Indian women that justify the civilizing mission, see Antoinette Burton. Burdens of History: British Feminists, Indian Women, and Imperial culture, 1865-1915. Chapel Hill: University of North Carolina Press, 1994.Also see Inderpal Grewal. Home and Harem: Nation, Gender, Empire, and the Cultures of Travel. Durham: Duke University Press, 1996. Also see the groundbreaking work of Gayatri Chakravorty Spivak and Himani Bannerjee.
} 
photography clubs which was based on shared understandings of artistic photography. ${ }^{261}$ This

shared sense of community through photography is exemplified by the Linked Ring Brotherhood formed in 1892, where members of the Ring "referred to each other as brother links." ${ }^{262}$ Similar to the way YMCA members are configured as brothers in Christ, their shared sense of photographic styles certainly would have brought these men closer together. The YMCA certainly served as platform to bring men and photography together, as photographer Frederick H. Hill ${ }^{263}$ recalls meeting Minor White at a Portland YMCA because of its camera club and photographic facilities. ${ }^{264}$

Figures 22, 24, and 26 appear in Archer's album. But they were also intended as souvenirs for Mrs. Jessop. At the same time, Brown places similar images (Fig.21 and Fig.23) in his family album. Although Brown's depictions are not normally associated with domestic themes, their placement in an album situates them within discourses of family. ${ }^{265}$ Gillian Rose asserts that for a photograph to be deemed as "family photography" it must be treated like one. ${ }^{266}$ For Brown and his companions, their "doing" of family photography involves the circulation and exchange of their photographs across personal and institutional archives. The aesthetic appeal of these images may overshadow the context of creation, particularly "in cultures where it is photography and the

\footnotetext{
${ }^{261}$ Margaret Harker. The Linked Ring: The Secession Movement in Photography in Britain, 1892-1910. London: Heinemann Ltd, 1979. Page 64.

${ }^{262}$ Ibid, page 45.

${ }^{263}$ Author (with George Venn) of Darkroom Soldiers: Photographs and Letters from the South Pacific Theater World War II. Caldwell, Idaho: Photosmith books, 2007.

${ }^{264}$ The lobby of the Portland YMCA displayed photographs made by its camera club, Minor White used this opportunity for a photographic exercise asking Hill to pick out the best photograph, for more see Frederick H. Hill. "When I knew Minor White" in History of Photography 16:2 (1992) page 149.

${ }^{265}$ Laura Wexler. Tender Violence: Domestic Visions in an Age of U.S Imperialism. Chapel Hill and London: University of North Carolina Press, 2000. Page 21.

${ }^{266}$ Gillian Rose. Doing Family Photography: The Domestic, The Public and The Politics of Sentiment. Surrey and Burlington: Ashgate Publishing, 2010. Page 23.
} 
photographer that are exotic, the imbalance in favour of the photographer is necessarily even more overwhelming." ${ }^{267}$

Yet, if the dominating gaze of the photographer is overwhelmingly asymmetrical, how can there be any room for resistance to the objectifying gaze of the YMCA members? While some of the women and children looked away from the camera, thereby complicating the visual cohesion of compositional symmetry between Brown and Archer's photographs. Is this the only visual gesture that can be read as resistance to hegemonic ways of looking? Instead, Michael Aird offers an alternative through the conception of "'looking past' the stereotypical way in which their ancestors and relatives have been portrayed." ${ }^{268}$ In other words, a photograph can be far more complex and layered in meaning than its original conception. ${ }^{269}$ For example, Aird states "I have watched as a woman viewed photographs taken in the 1890s of her grandmother posing barebreasted in a photographic studio... Yet she seemed undisturbed by the uncharacteristic way in which the photographer portrayed her grandmother." ${ }^{270}$ This is not to suggest that the histories of colonial India and Aboriginals in Australia are the same; instead it is a gesture towards the possibility of recuperation, which acts as a type of "homecoming: the naming of the formerly anonymous, the individuation and recognition of persons whose work in the archive had usually been to 'typify'--that is to exemplify some category." ${ }^{271}$ While it is imperative to read against the grain to deconstruct the assumptions that inform a colonial archive, it is equally essential to extend

\footnotetext{
${ }^{267}$ Susan Close. "The Camera and the Contact Zone: Re-Envisioning the Representation of Aboriginal Women in the Canadian North” in Transculturation in British Art, 1770-1930. Edited by Julie F. Codell. Surrey and Burlington: Ashgate, 2012. Page 117.

${ }^{268}$ For more and the limits of "looking past" See Michael Aird "Growing up with Aborigines" in Photography's Other Histories. Edited by Christopher Pinney and Nicolas Peterson. Durham: Duke University Press, 2003. Page 24.

${ }^{269}$ Christopher Pinney. "Introduction: How The Other Half..." in Photography's Other Histories. Edited by Christopher Pinney and Nicolas Peterson. Durham: Duke University Press, 2003. Page 19.

${ }^{270}$ Michael Aird. "Growing up with Aborigines" in Photography's Other Histories. Edited by Christopher Pinney and Nicolas Peterson. Durham: Duke University Press, 2003. Page 65.

${ }^{271}$ Christopher Pinney. "Introduction: How The Other Half..." in Photography's Other Histories. Edited by Christopher Pinney and Nicolas Peterson. Durham: Duke University Press, 2003. Page 18.
} 
agency to those depicted, to make space for alternative reading practices. Such a divergent approach would allow, in turn, for the possibility of other frameworks for picturing family-an issue that these photographs raise but stop short of addressing..$^{272}$

\footnotetext{
${ }^{272}$ This is an issue that remains outside the scope of this study.
} 


\section{Conclusion}

Marianne Hirsch states: "because of their conventional nature and the monocular len's ideological effect, family photographs can reveal the operation of the familial gaze. If we are interested in the interaction of the familial gaze and familial looks, however, we have to go beyond the pictures themselves. ${ }^{273}$ In other words, we have to expand understandings of family photography beyond their often domestic realm of production. In a similar vein, this thesis examined the photographic crossover between Brown's personal album and the YMCA's visual archive. By examining this crossover, I showed how photographs reinforced the institution's construction of the ideal family as white, Christian, and middle-class.

By the 1910s, the YMCA increasingly emphasized its family-orientated image towards the American public, particularly emphasizing marriage in response to growing anxiety over homosexuality. This emphasis was so palpable that, during World War I, publications like American Magazine presented YMCA leaders like John Mott as a "family man" ${ }^{274}$ and the visual depiction of this was confirmed through a photograph of both the Motts and their six children. ${ }^{275}$ It is for this reason that within the American psyche it maybe inconceivable that:

Growing up in the Anglo-American world in the first few decades of the twentieth century meant being constantly bombarded with lectures on eugenics from ethical, debating, and the philosophical societies; health, women's and medical associations -sometimes even the $\mathrm{YMCA}^{276}$

\footnotetext{
${ }^{273}$ Marianne Hirsch. Family Frames: Photography, Narrative, and Postmemory. Cambrige, Mass: Harvard University Press, 1997. Page 11.

${ }^{274}$ As cited in John Donald Gustav-Wrathall. Take the Stranger by the Hand: Same-Sex Relations and the YMCA. Chicago: University of Chicago, 1998. Page 109.

${ }^{275}$ Ibid.

${ }^{276}$ Marouf Arif Hasian Jr. The Rhetoric of Eugenics in Anglo-American Thought. Athens: University of Georgia Press, 1996. Page 37. Although the YMCA is not the topic of her study, Shawn Michelle Smith quotes this passage to illustrate how eugenics permeated white middle class life. For more see Shawn Michelle Smith. American Archives: Gender, Race, and Class in Visual Culture. Princeton: Princeton University Press, 1999. Page 129.
} 
This passage is critical because it illustrates that even the YMCA was not exempt from the infiltration of eugenics, a racist strand of scientific study whose adherents believed in perfecting the human population through genetic inheritance. ${ }^{277}$ The YMCA, like many Protestant American organizations, embraced the discourses of eugenics ${ }^{278}$ by participating in Race Betterment Conferences, ${ }^{279}$ outreach with immigrant men, ${ }^{280}$ and sex education. ${ }^{281}$ Brown's YMCA branch was not exempt from these practices, as understood through YMCA secretary E.M. Jenkins's Annual report for 1914, which reads:

Gradually there has grown up a feeling that the Wellington Branch is only for AngloIndians and the Chowringhee Branch only for Europeans...though we may not evade or ignore the fact that there are deep-rooted prejudices and differences between the pure and the mixed races of India, as there are between the Negroes, Mulattos, and whites of the States. As an Association we cannot take cognizance of any distinction based on colour or class lines. ${ }^{282}$

Certainly, the photographic crossover between Brown and the YMCA's institutional archive reinforces the claims of the YMCA's undercurrents of Anglo-Saxon superiority. These undercurrents are evident in the way that Brown positioned himself in relation to the YMCA's familial gaze, perpetuating the myth of the white, middle class, Christian fraternal family. At the same time, as much as Brown and his YMCA companions tried to visually control the construction of imagery through employing shared leisure and artistic conventions, "the photographer can never fully control the resulting photograph, and it is the lack of control and the

\footnotetext{
${ }^{277}$ In 1883, Francis Galton coined the term "eugenics" from the Greek meaning "good in birth," in relation to his plan to improve the human race through better breeding based on a hierarchy of races with Anglo-Saxon being the most superior. For more on eugenics in the progressive era see Donald K. Pickens. Eugenics and the Progressives. Nashville, Vanderbilt University Press, 1968.

${ }^{278}$ Christine Rosen. Preaching Eugenics: Religious Leaders and the American Eugenic Movement. Oxford: Oxford University Press, 2004.

${ }^{279}$ Ibid, page 89.

${ }^{280}$ For more on German immigrants becoming "old stock" see Russell Andrew Kazal. Becoming Old Stock: The Paradox of German-American Identity. Princeton: Princeton University Press, 2004.

${ }^{281}$ Alexandra M. Lord. "Models of Masculinity: Sex Education, the United States Public Health Service and the YMCA, 1919-1924" in Journal of the History of Medicine and Allied Sciences 58:2 (2003) pages 123-152.

${ }^{282}$ E.C Jenkins. Annual Report for 1914. Correspondence Files Box 6. India Files. Kautz Family YMCA Archives.
} 
resulting excess that permits recoding, "resurfacing," and 'looking past."”283 This excess, as I discussed in Chapter Two, can be seen in the loose page, which contains the image captioned Residents YMCA Calcutta 1911 (Fig.9), and mounted in relation to the images of Indian women and children. In a sense, the choice to include such images in Brown's personal album brings two otherwise socially disparate groups together, suggests an element of egalitarianism.

Upon closer inspection of this juxtaposition, the photographic "excess" is best understood in the photograph captioned A Maternal Group (Fig.29). The infants that the women are holding appear to be in distress, with two of the three children seeming to be in tears. In fact, the child held by the woman on the right, directly stares at the photographer's lens, thereby reminding the viewer of the complex contexts behind this photographic act. Ariella Azoulay argues that there is a "civic skill” which emerges from viewing a photograph, where the photographed subject's suffering activates an obligation to act. ${ }^{284}$ This is not to speculate whether Brown or his YMCA companions employ such a practice $;^{285}$ instead Brown and Archer's employment of pictorialist and leisure conventions suggests a particular shared citizenry amongst the others they depict and potential spectators, one with the potential to challenge the pleasure that men experienced in looking at these exoticized and salvational subjects.

Throughout this study, the materiality of Brown's album has been a gateway to the object's social biography, yet an element of the unknown remains. On the upper right corner of this same loose page under the caption Contented (Fig.30), there is another caption in pencil marked $\mathrm{S}$ and above the right corner of the photograph there is the number 61 captioned in red ink. It is not

\footnotetext{
${ }^{283}$ Christopher Pinney. Photography’s Other Histories. Durham: Duke University Press, 2003. Page 25.

${ }^{284}$ Ariella Azoulay. The Civil Contract of Photography. Translated by Rela Mazali an Ruvik Danieli. New York: Zone Books, 2008. Page 14 .

${ }^{285}$ This is not suggesting that Azoulay's argument is directly applicable in late colonial India, for more see Christopher Pinney. "Civil Contract of Photography in India" in Comparative Studies of South Asia, Africa and Middle East 35:1 (January 2015) Pages 21-34.
} 
known when these captions were added or what they mean. One indicator that these captions were possibly added after the images were taken is on another loose page (Fig.31) underneath a photograph of a clock tower captioned CLOCK TOWER. DELHI in black upper-case handwriting, another caption in pencil reads Note: clock tower in chandni chowk collapsed in 1954. Brown passed away on September $24^{\text {th }} 1977 ;^{286}$ therefore, it is certainly possible, depending on when this object was acquired by the photographic dealer or Cyrus Jhabvala, that the caption was not added by Brown. Captions in pencil are also seen on the inside of the back cover of Brown's leather bound album (Fig. 32) which reads No.2 135 photos, which directly corresponds to the number of gelatin silver prints that are mounted in the album. The captions in pencil appear to be concerned with tracking or keeping count of imagery, another loose page features a pencil captioned 1 dozen written beside yet another photograph captioned in blank ink Chamba trip (Fig. 33). The importance is not about deciphering who added the captions. Instead, these material traces demonstrate family photography's fluidity as it circulates across diverse institutions from personal collections, commercial markets, and museum collections.

\footnotetext{
${ }^{286}$ College of the Resurrection registrar, Brown's Aluma mater, personal communication, November 27, 2015.
} 
$\underline{\text { Figures }}$

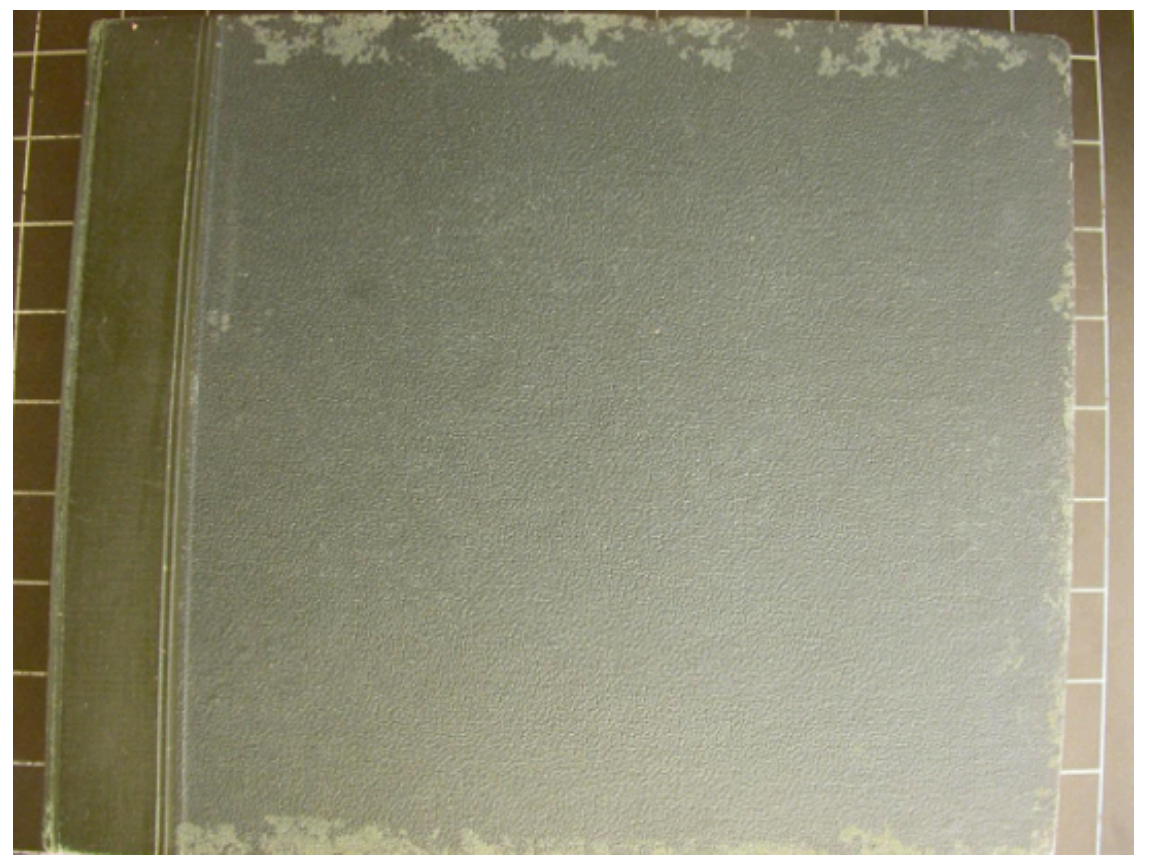

Figure 1. Leather-bound album, Royal Ontario Museum collection. 


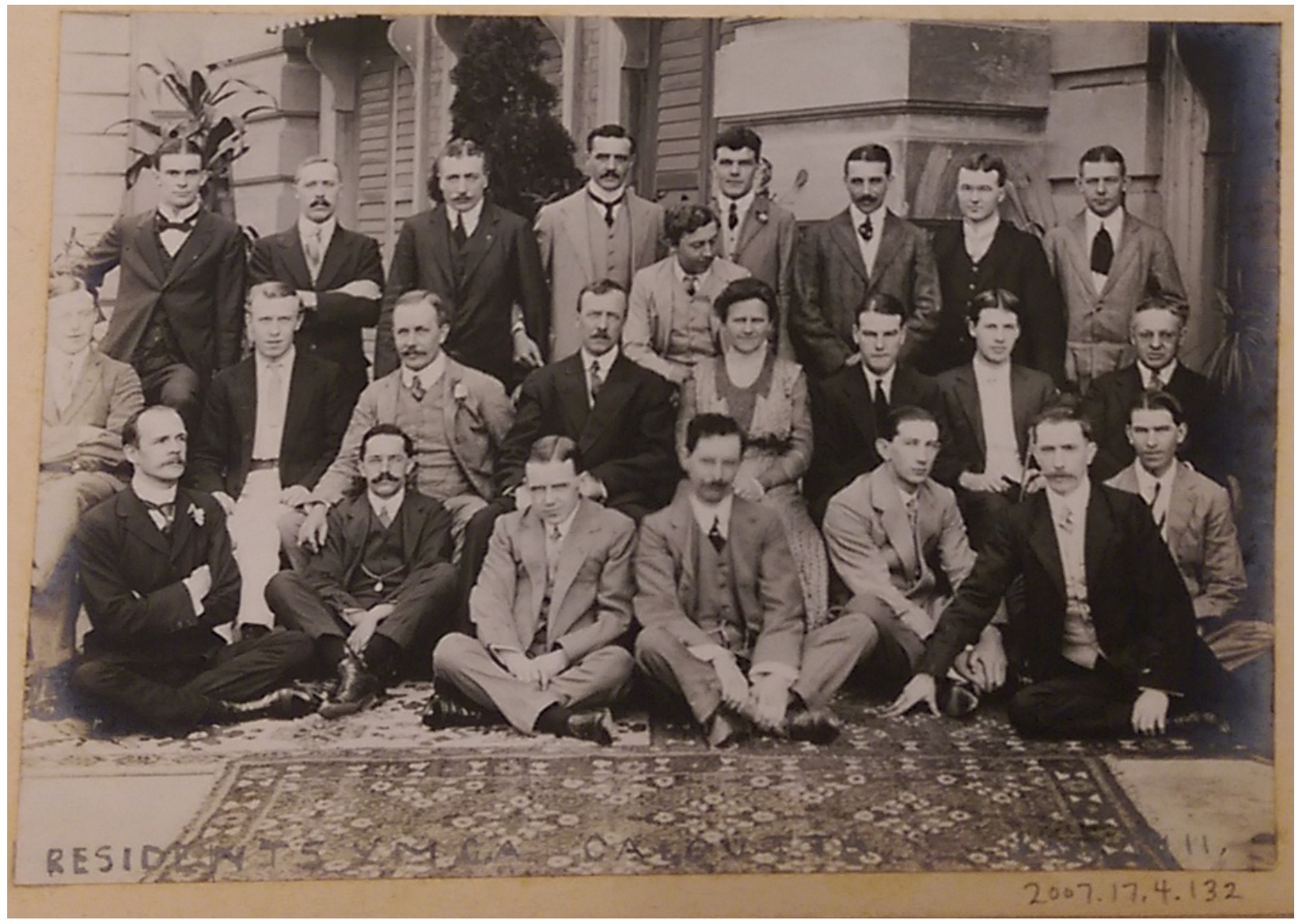

Figure 2. Photograph from loose page associated with album of Cyril J. Brown Royal Ontario Museum collection. 


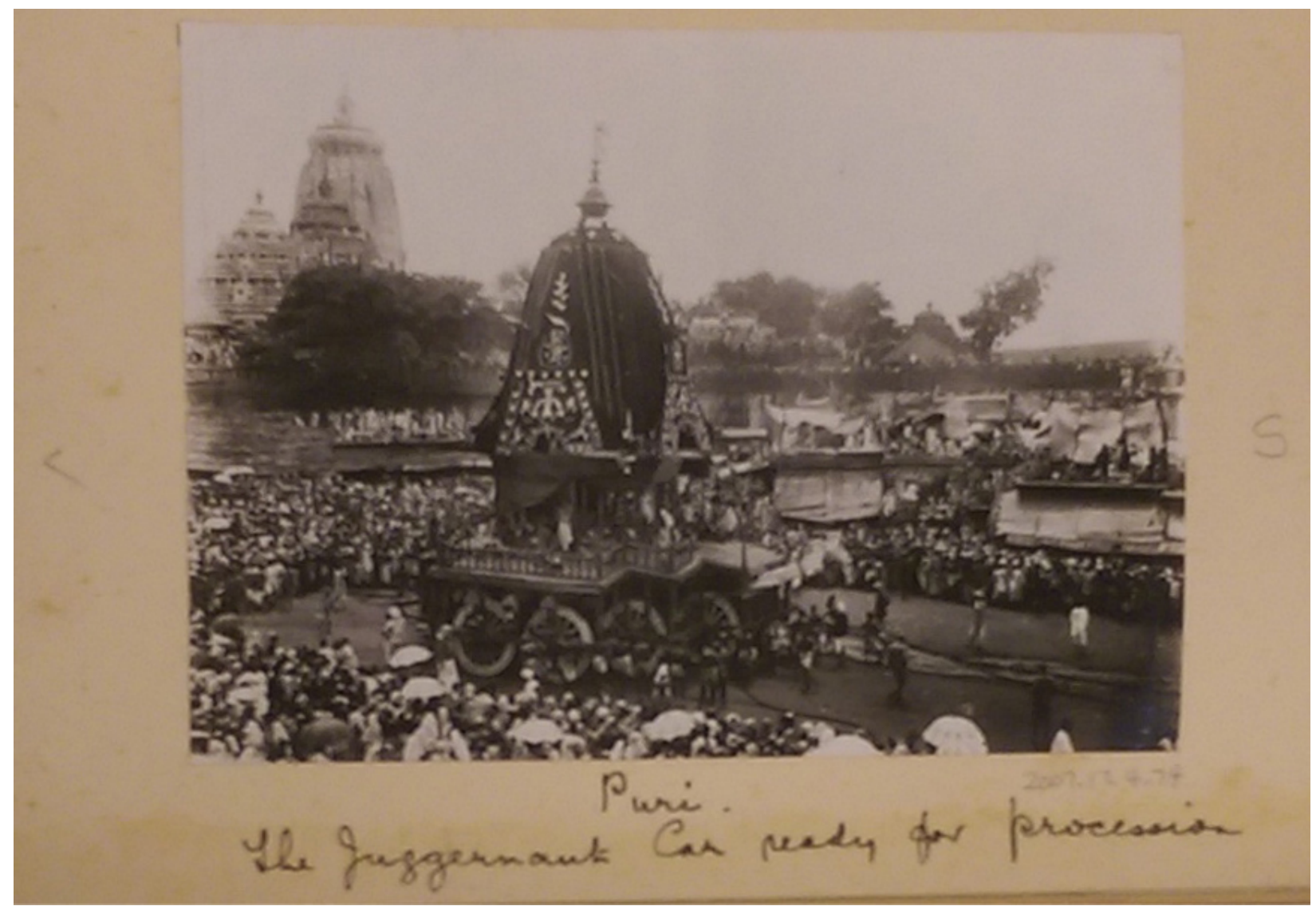

Figure 3. Photograph on page 36 from album of Cyril J. Brown, Royal Ontario Museum collection. 


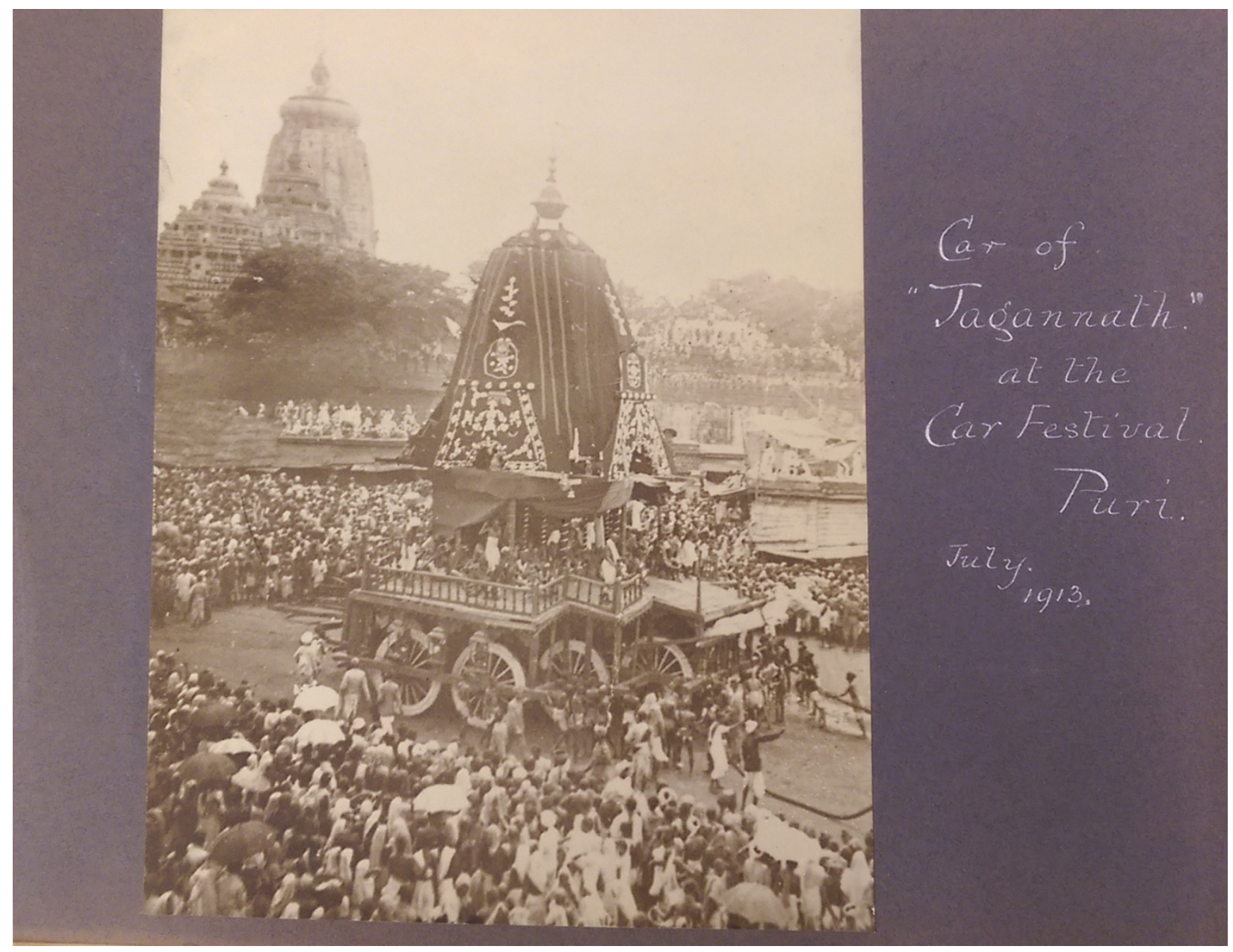

Figure 4. Page ten from album of W. Archer, scrapbook collection, Kautz family YMCA Archives, University of Minnesota. 


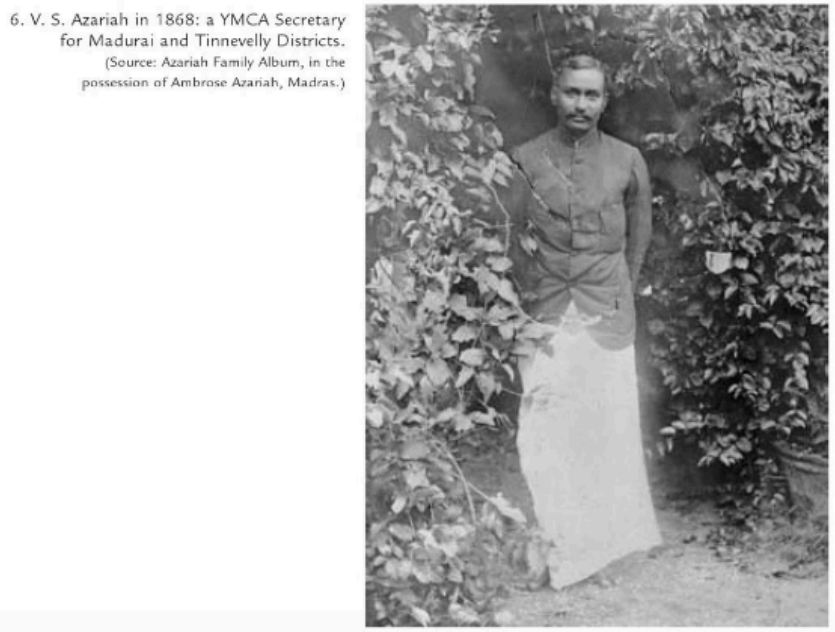

Figure 5. Digital reproduction, In the Shadow of the Mahatma: Bishop V.S Azariah and the Travails of Christianity in British India, page 220.

10. The making of an Indian bishop, c. 1909:

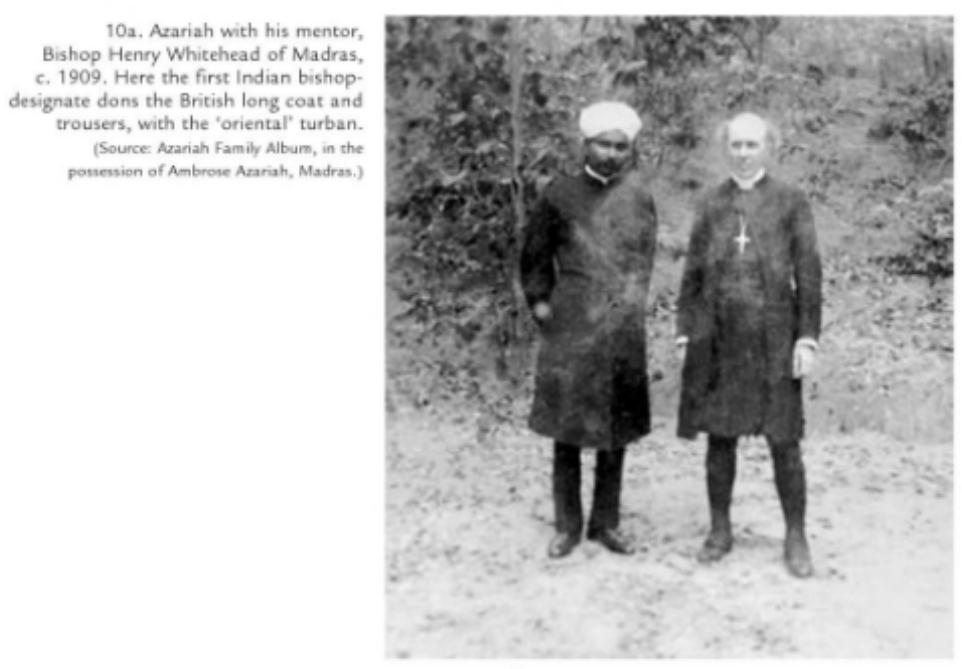

Figure 6. Digital reproduction, In the Shadow of Mahatma: Bishop V.S Azariah and the Travails of Christianity in British India, page 200. 


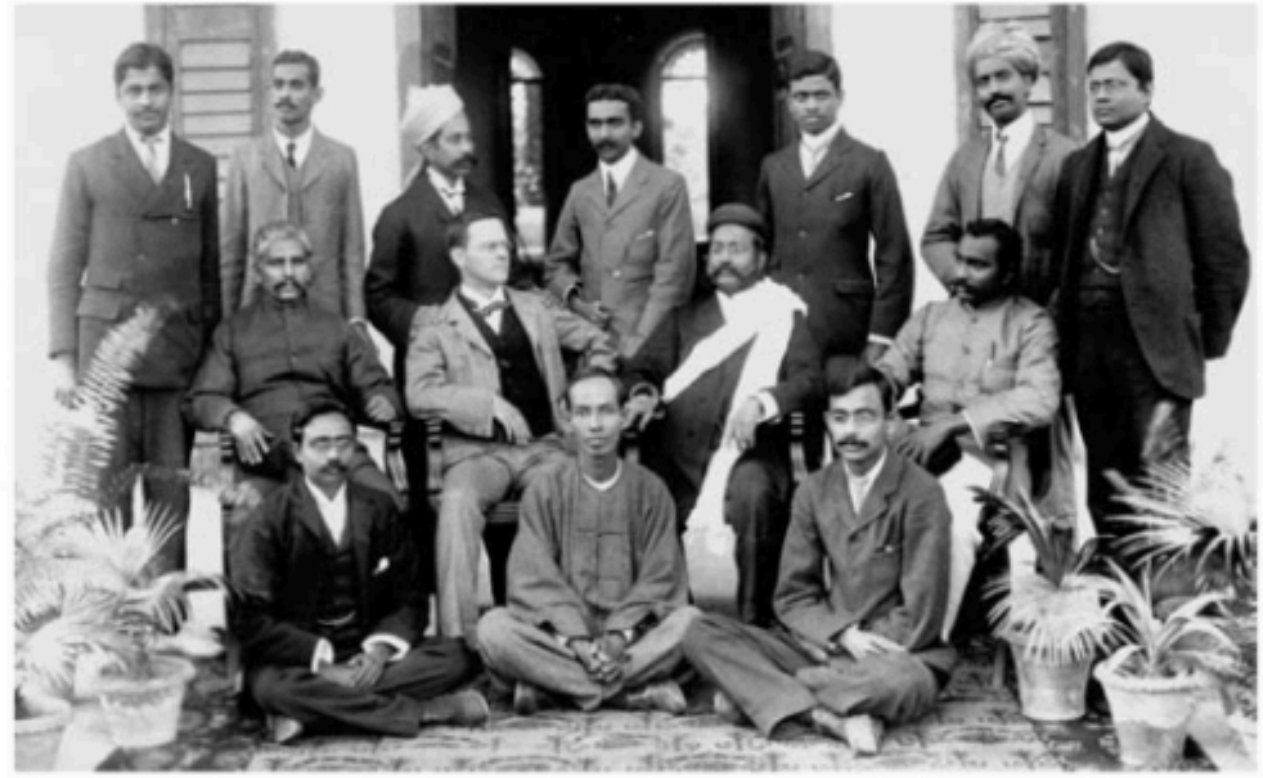

7. Founders of the National Missionary Society of India, Serampore, 25 Dec. 1905. Standing (left to right): S. N. Mukerji (Lahore), W. S. Ratnaval (Calcutta), R. Siraj-ud-din (Lahore), E. A. de Alwis (Kandy), J. W. N. Hensman (Calcutta), J. R. Chitambar (Lucknow), B. P. Sircar (Calcutta). Seated (left to right): J. M. Gulam Masih (Manipuri, U.P.), G. S. Eddy (Madras), S. V. Karmarkar (Chairman: Bombay), V. S. Azariah (Secretary: Palamcottah). Seated on floor (left to right): K. T. Paul (Madras), L. T. Ah Son (Rangoon), N. C. Mukeri! (Allahabad). Missing from picture: Rajah Sir Harnam Singh, K. C. Banerji, S. Sathianadhan, and Ah Pon. (Source: Yale Divinity School Library, C. S. Eddy Papers, Record Croup 32/IV/23/239.)

Figure 7. Digital reproduction from In the Shadow of the Mahatma: Bishop V.S. Azariah and the Travails of Christianity in British India, page 220. 


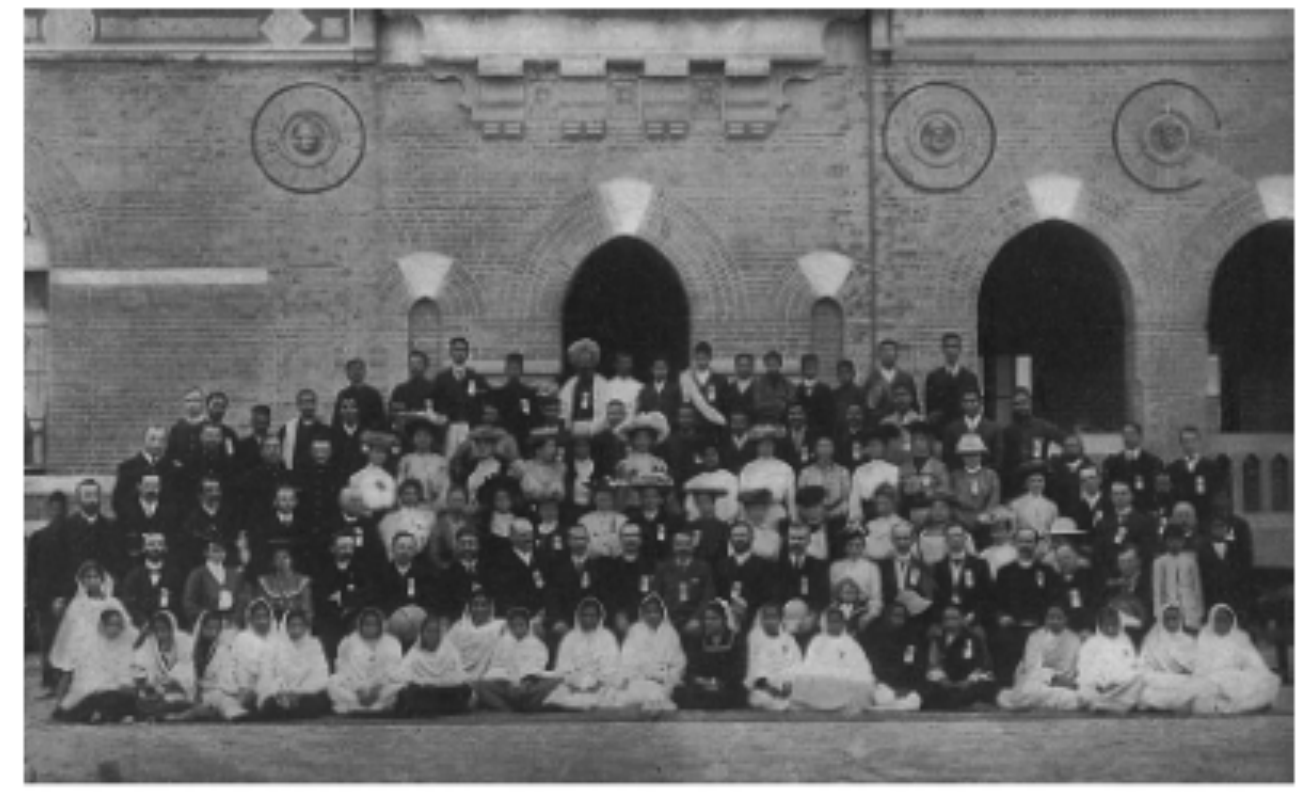

Fig. 6. Christian Endeavor leaders stressed its cross-racial and cross-national reach. Here the All-India Christian Endeavor Convention in Allahabad is depicted in Francis Clark, Christian Endeavor in All Lands: A Record of TwentyFive Years of Progress (United Society of Christian Endeavor, [1906]), 169.

Figure 8. Digital Reproduction from Reforming the World: The Creation of America's Moral Empire, page 83. 

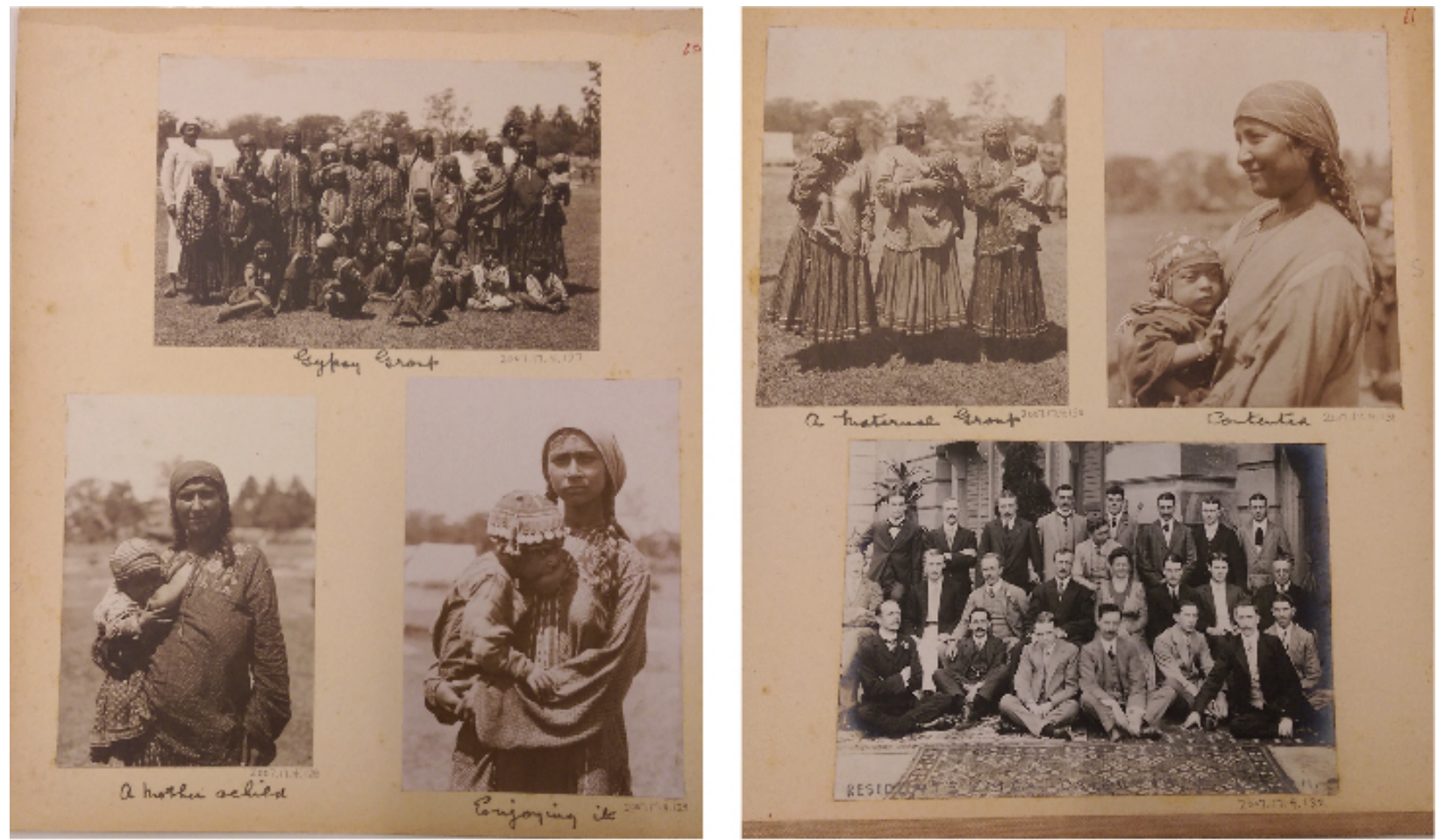

Figure 9. Recto and Verso of loose album associated with album of Cyril J. Brown, Royal Ontario Museum collection. 


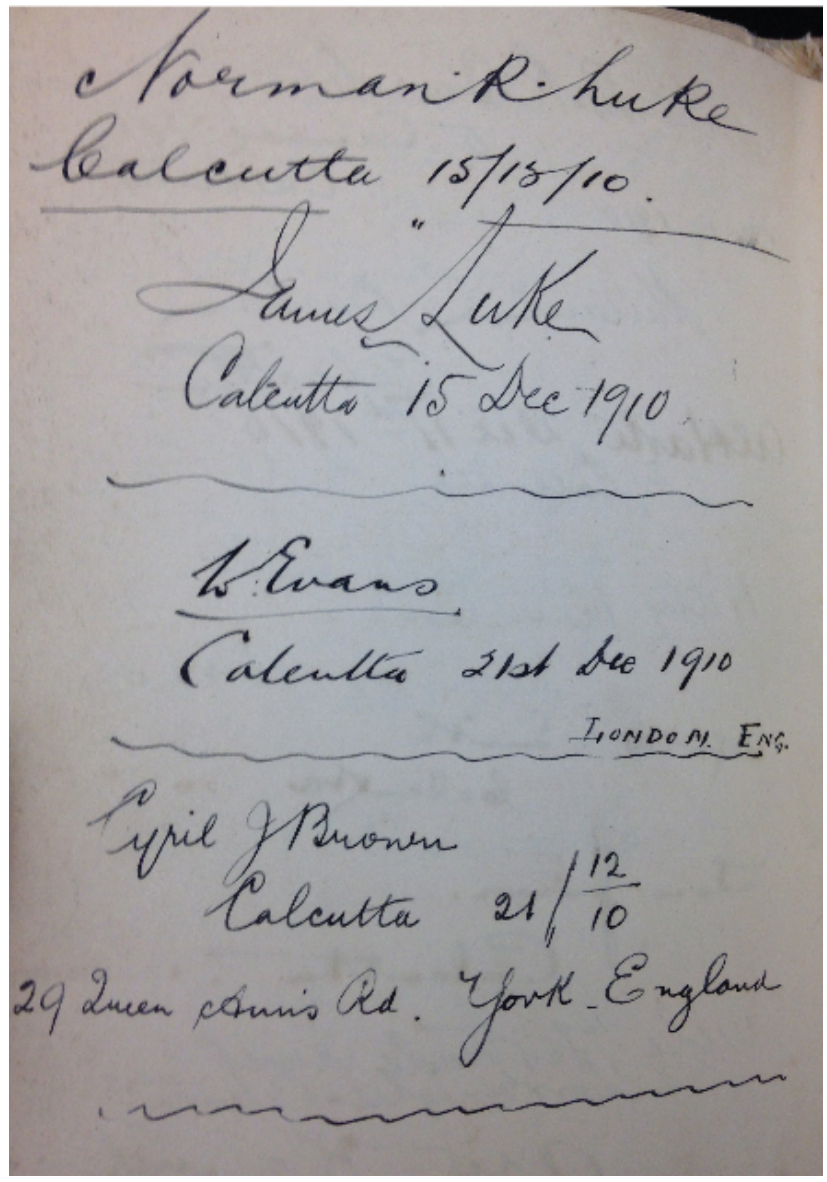

Figure 10. Brown's entry in Mr. Jessop's autograph book, biographical Files, Kautz Family YMCA Archives, University of Minnesota. 


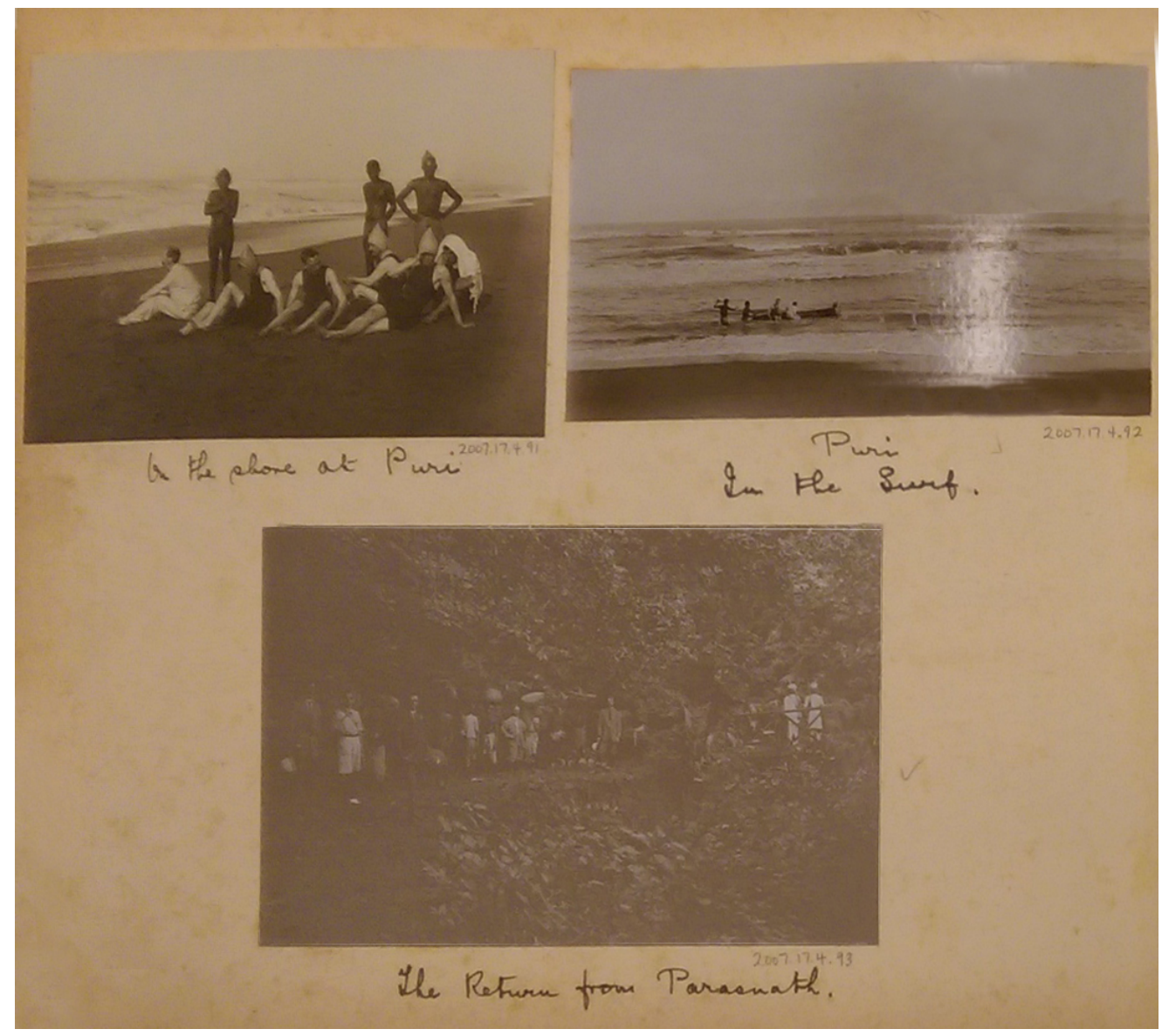

Figure 11- Page 44 from album of Cyril J. Brown, Royal Ontario Museum collection. 


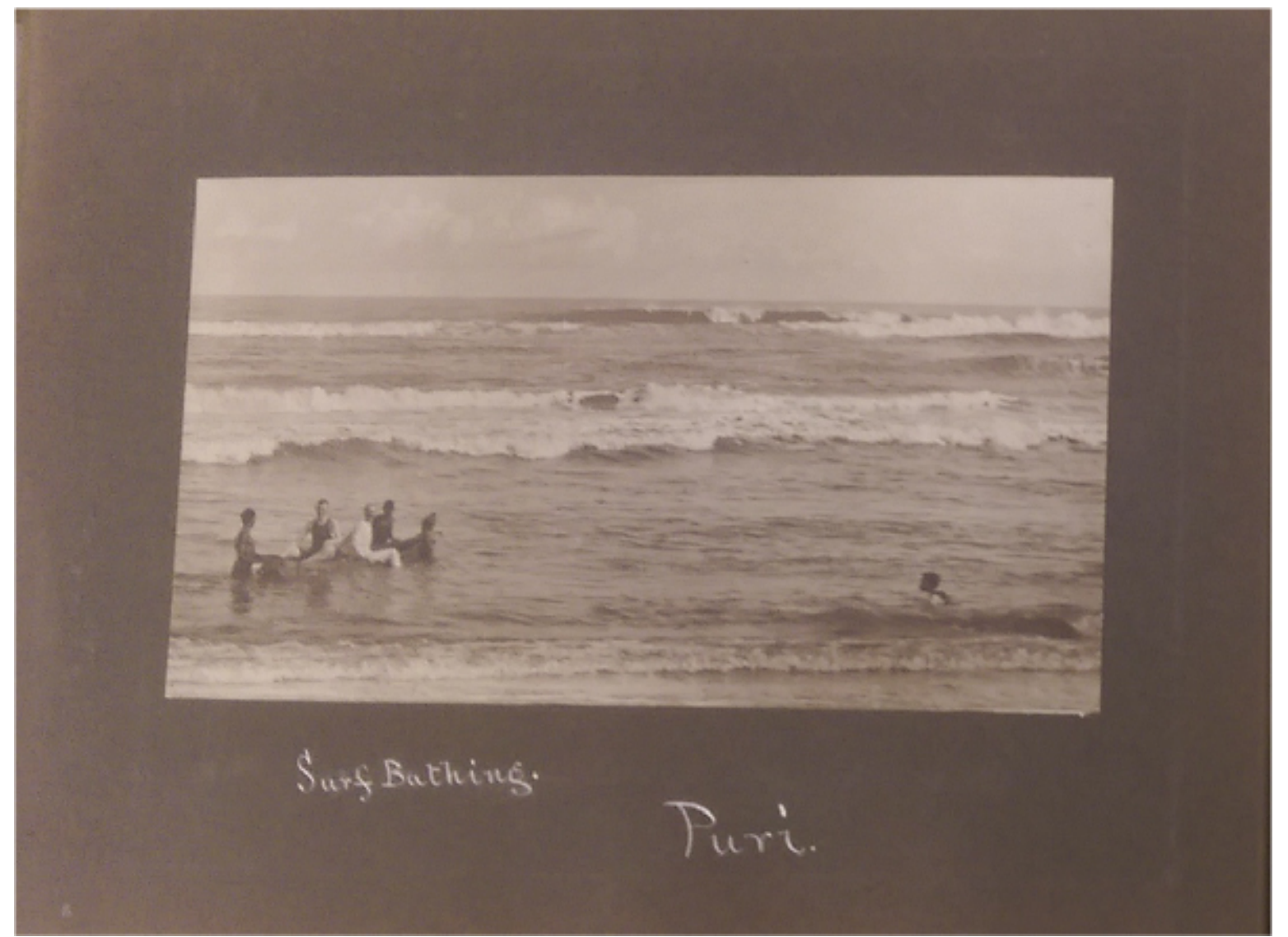

Figure 12. Page 20 from album of W. Archer, scrapbook collection, India files, Kautz YMCA Archives, University of Minnesota. 


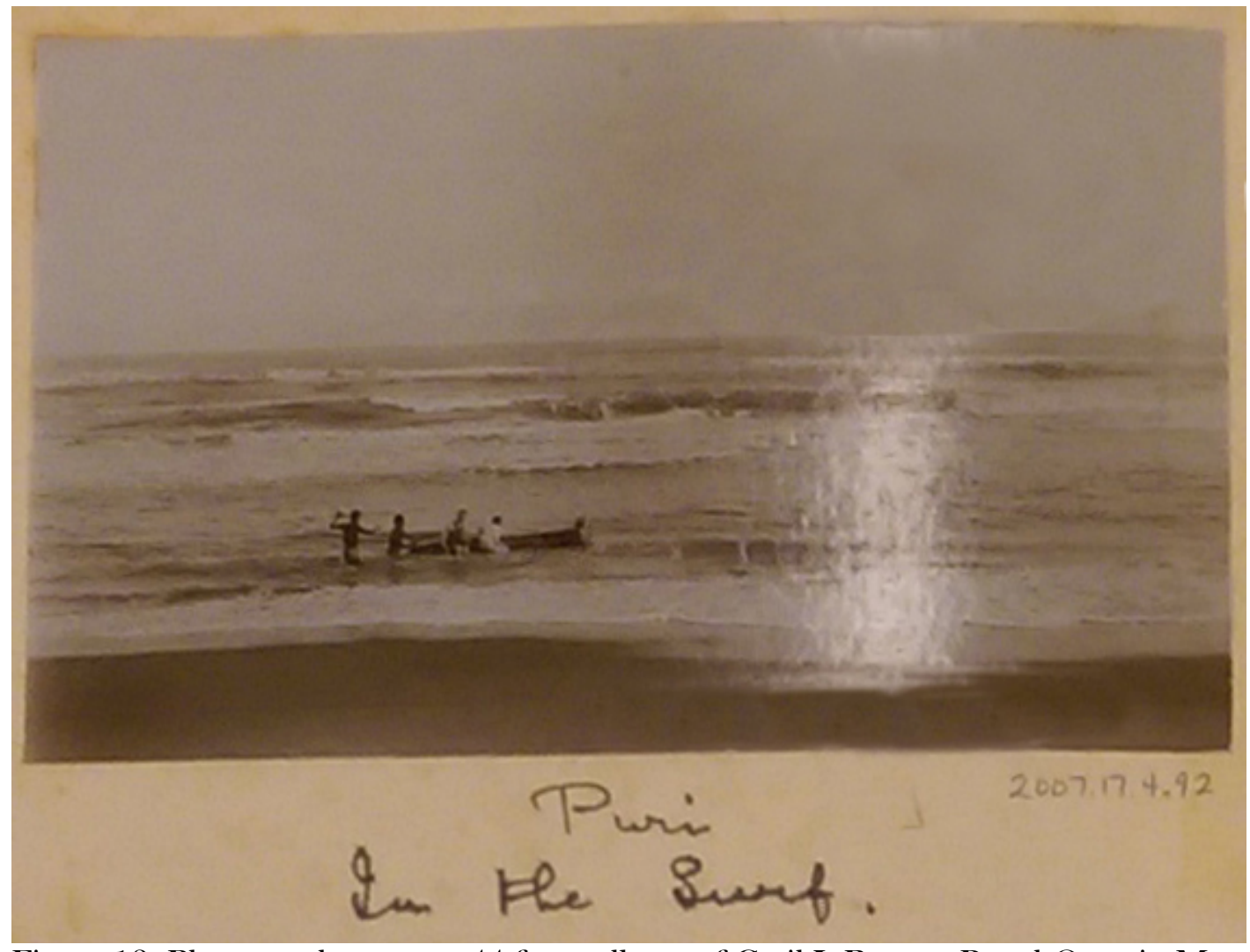

Figure 13. Photograph on page 44 from album of Cyril J. Brown, Royal Ontario Museum collection. 


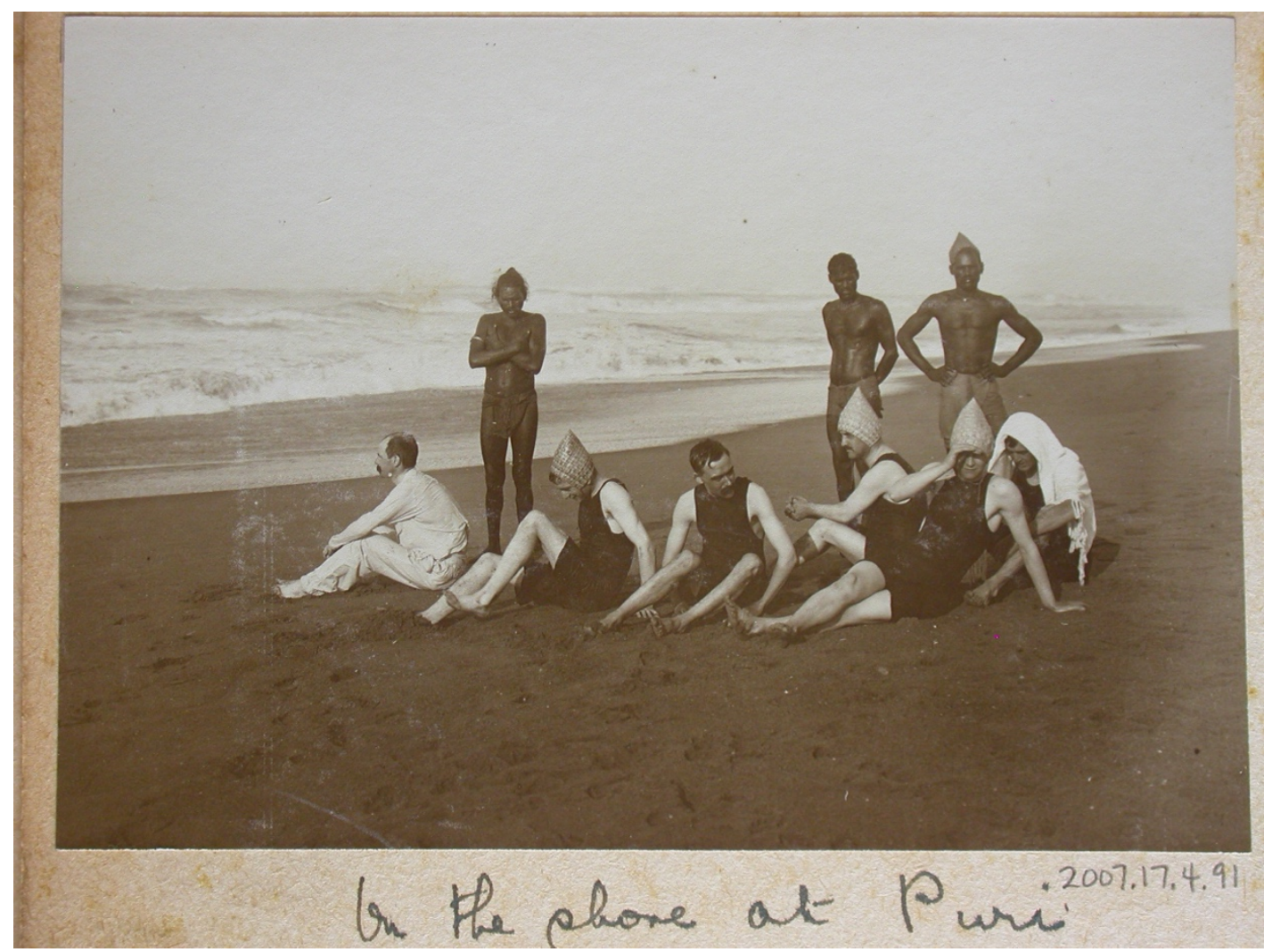

Figure 14. Photograph on page 44 from album of Cyril J. Brown Royal Ontario Museum collection. 

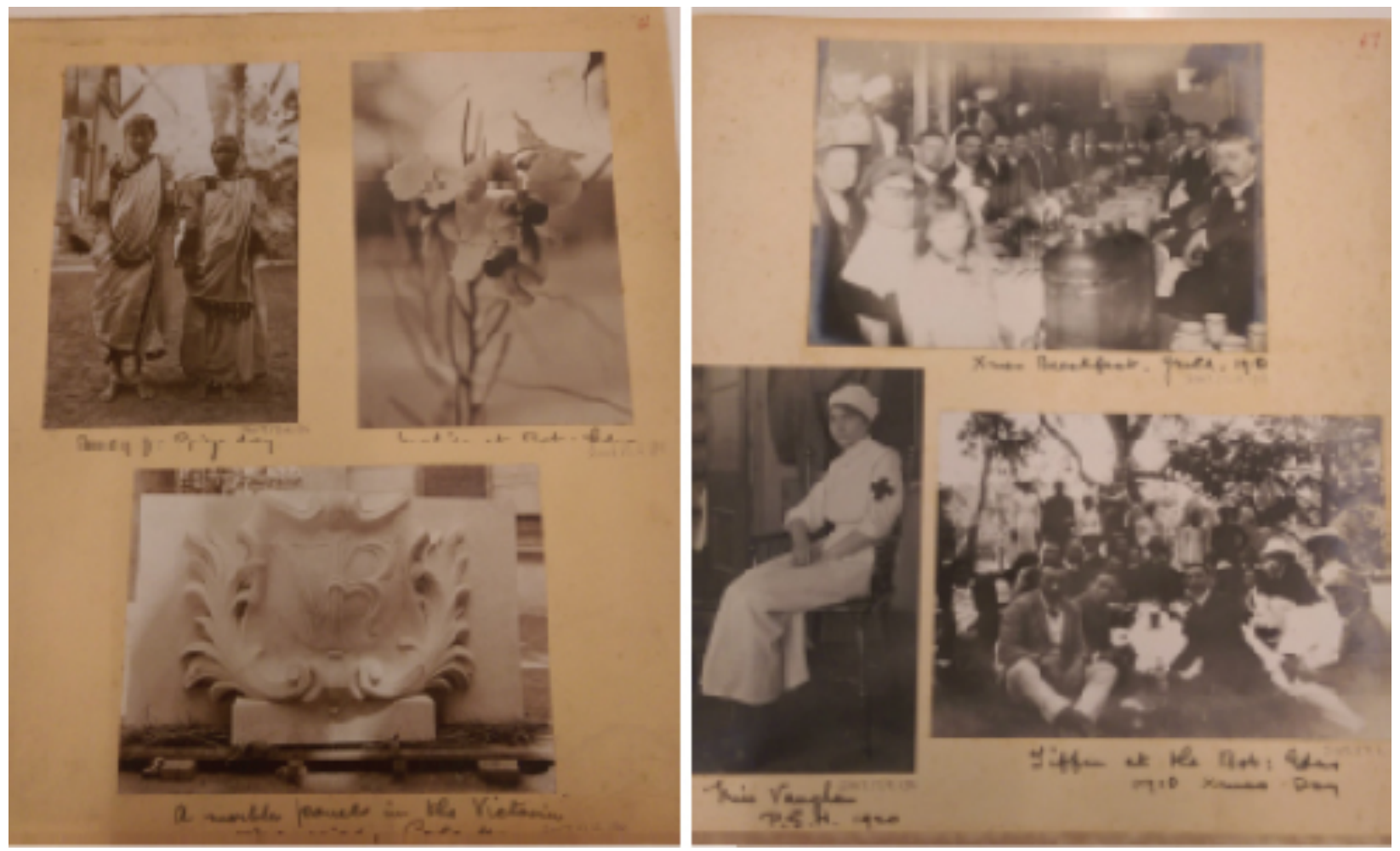

Figure 15. Recto and verso of loose page associated with Brown's album, Royal Ontario Museum collection. 


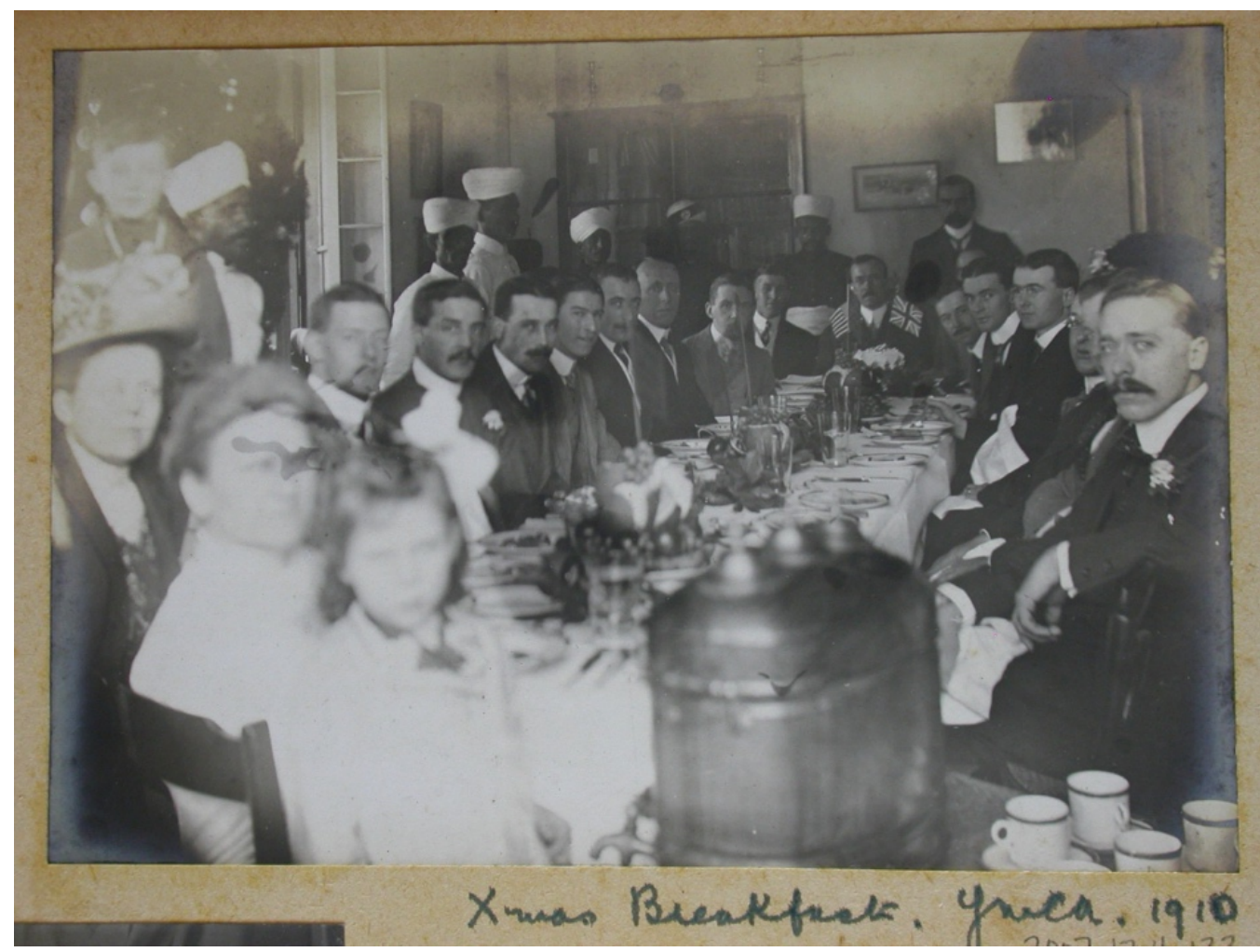

Figure 16. Photograph from loose page associated with Brown's album, Royal Ontario Museum collection. 


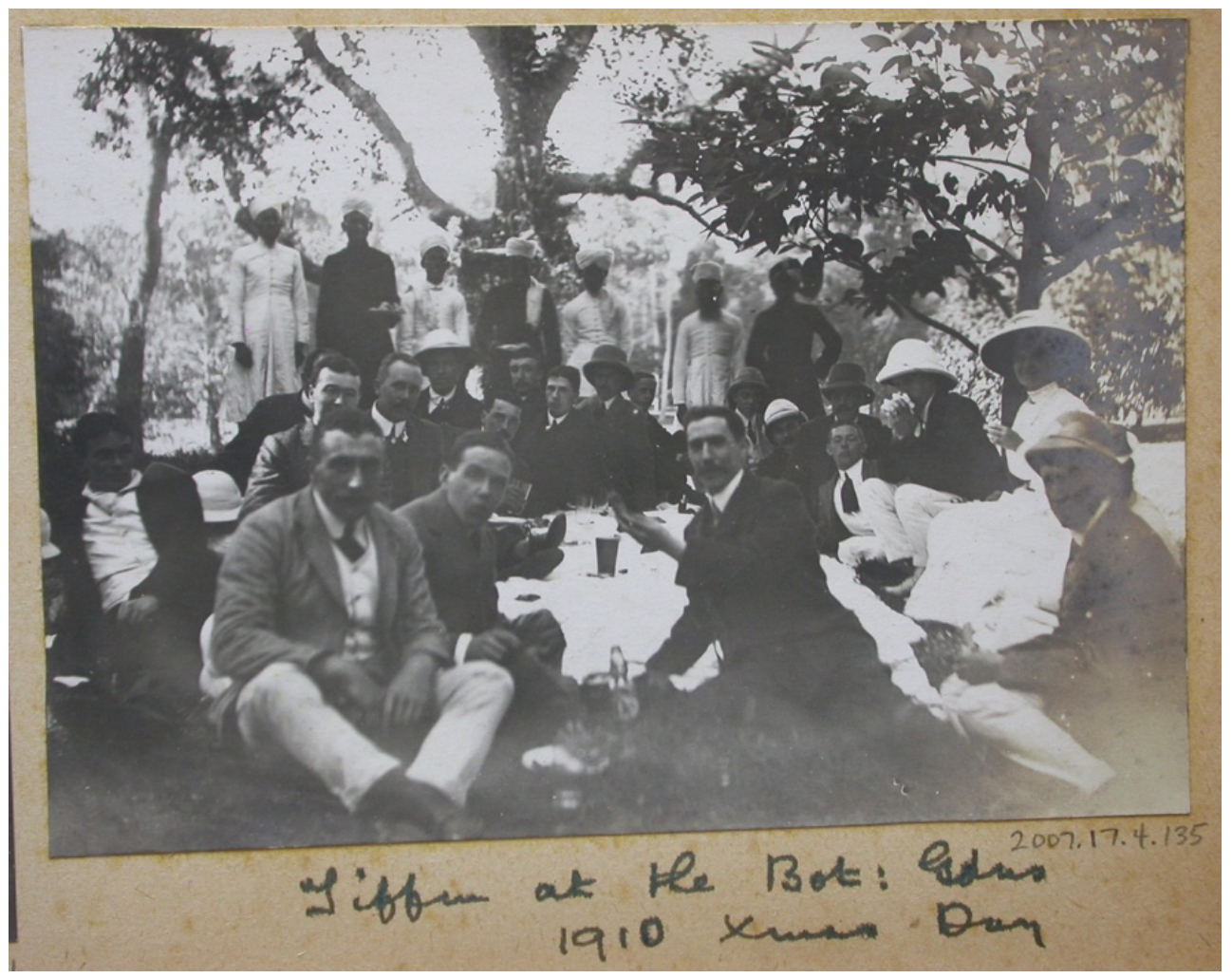

Figure 17. Photograph from loose page associated with Brown's album, Royal Ontario Museum collection. 


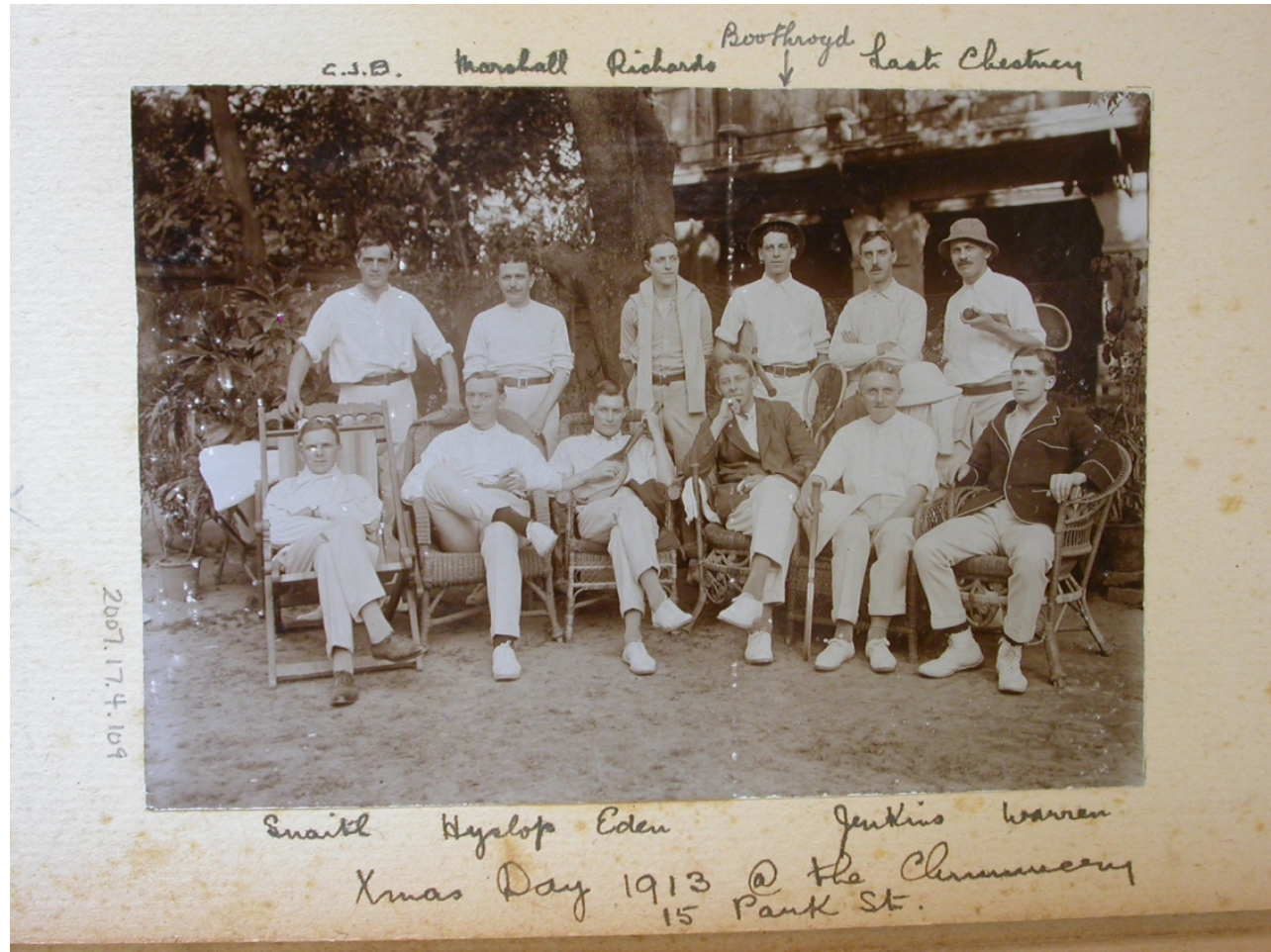

Figure 18. Photograph from page 53 from album of Cyril J. Brown, Royal Ontario Museum collection. 


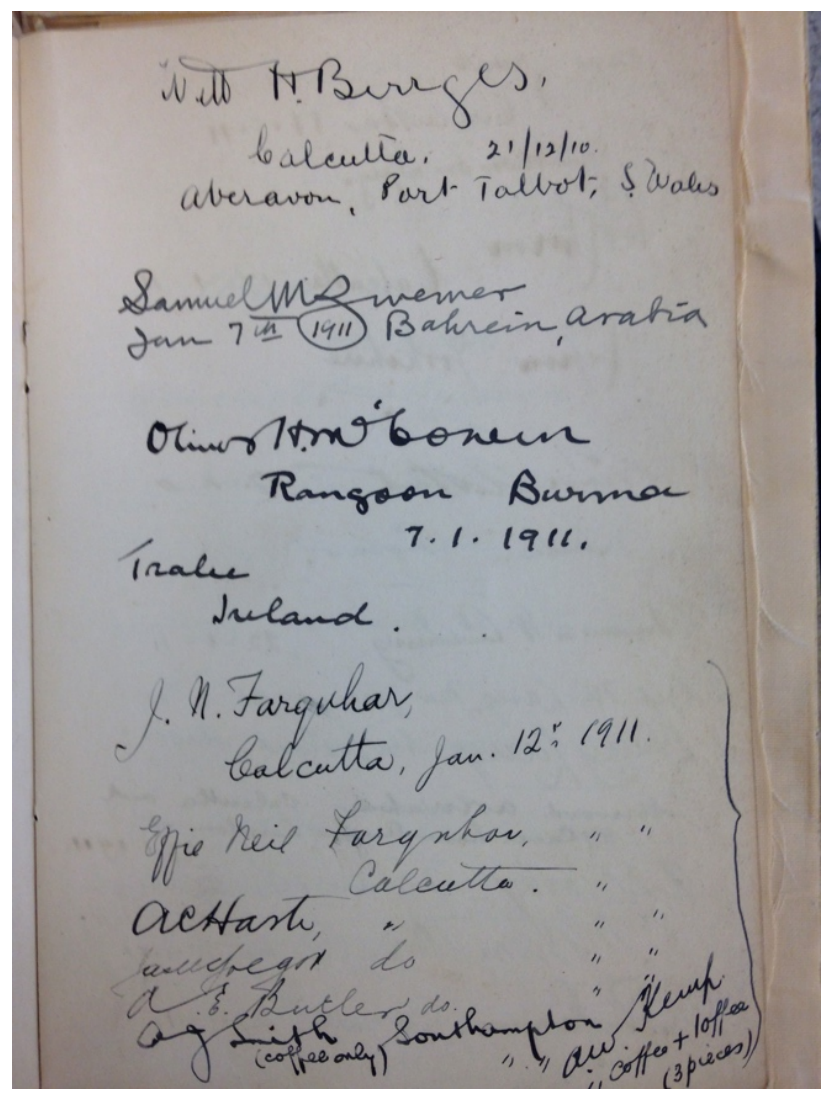

Figure 19. J. N Farquhar's entry in Mr. Jessop's autograph book, biographical files, Kautz Family YMCA archives. University of Minnesota. 


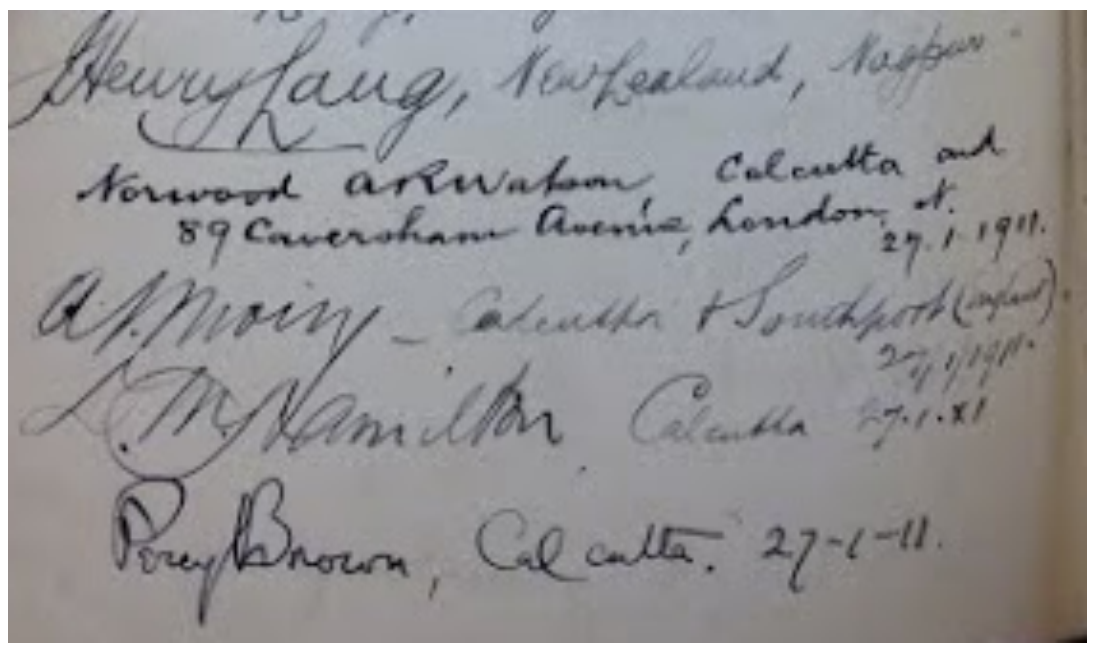

Figure 20. Percy Brown's entry in Mr. Jessop's autograph book, biographical files, Kautz Family YMCA Archives, University of Minnesota. 


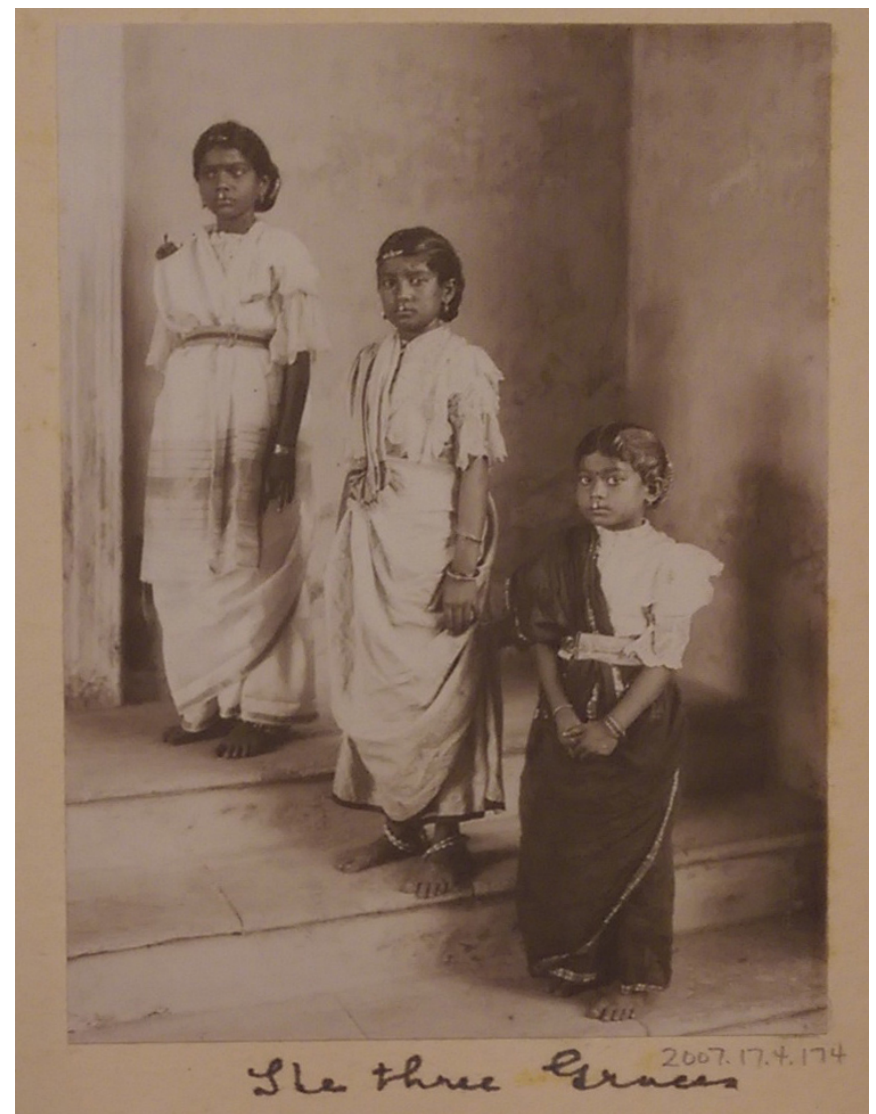

Figure 21. Photograph on loose page associated with Brown's album, Royal Ontario Museum collection. 


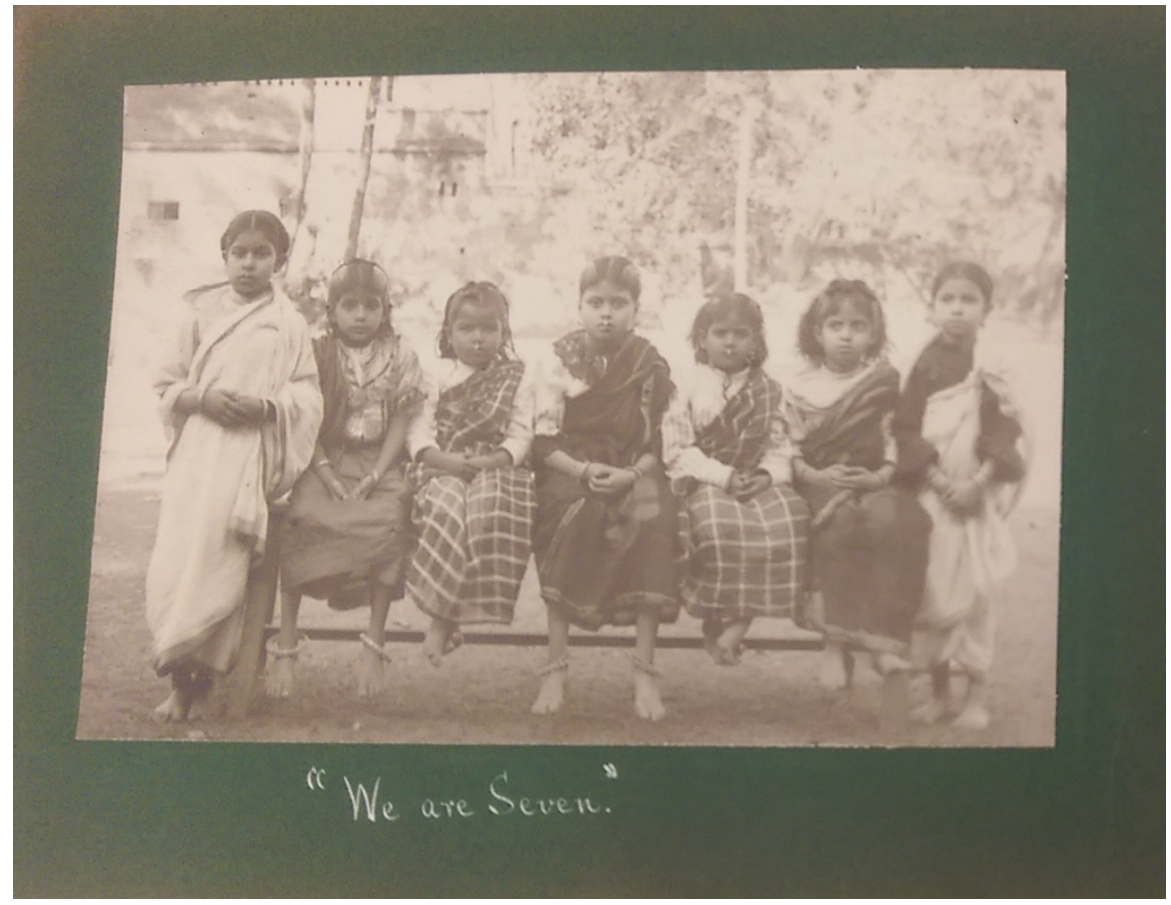

Figure 22. Page 18 from W. Archer's album, scrapbook collection Kautz Family YMCA Archive, University of Minnesota. 


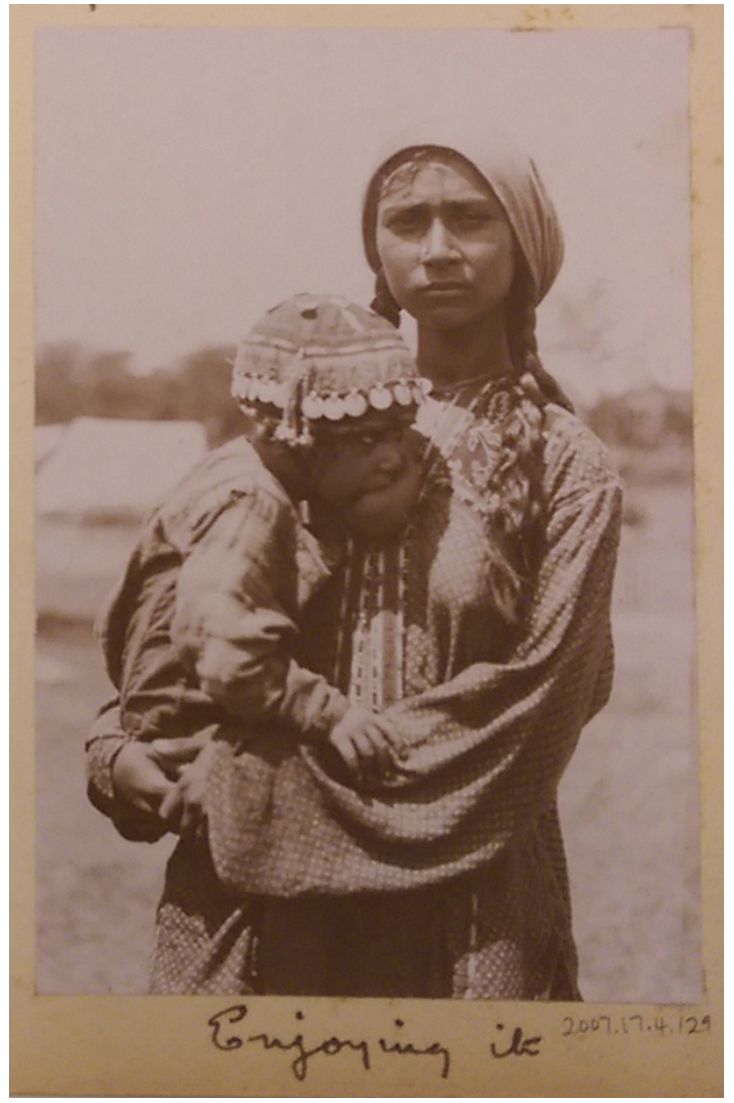

Figure 23. Photograph from loose page associated with Brown's album, Royal Ontario Museum collection. 


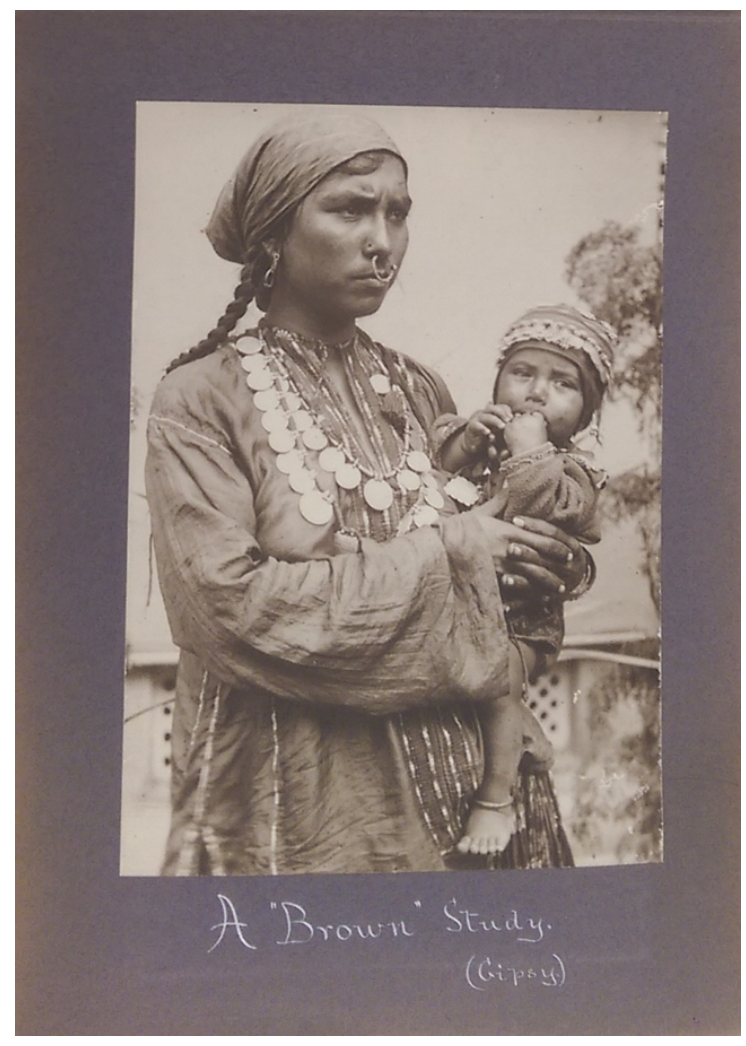

Figure 24. Page 14 from Archer's album, scrapbook collection, Kautz Family YMCA Archives, University of Minnesota. 


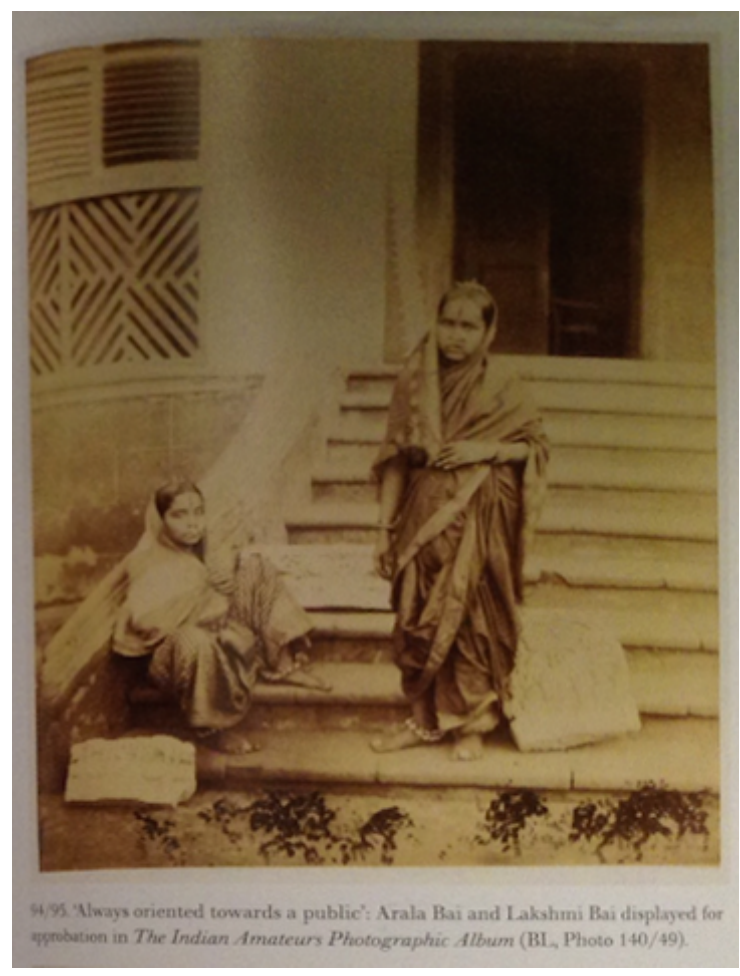

Figure 25. Digital reproduction from The Coming of Photography to India, page 119. 


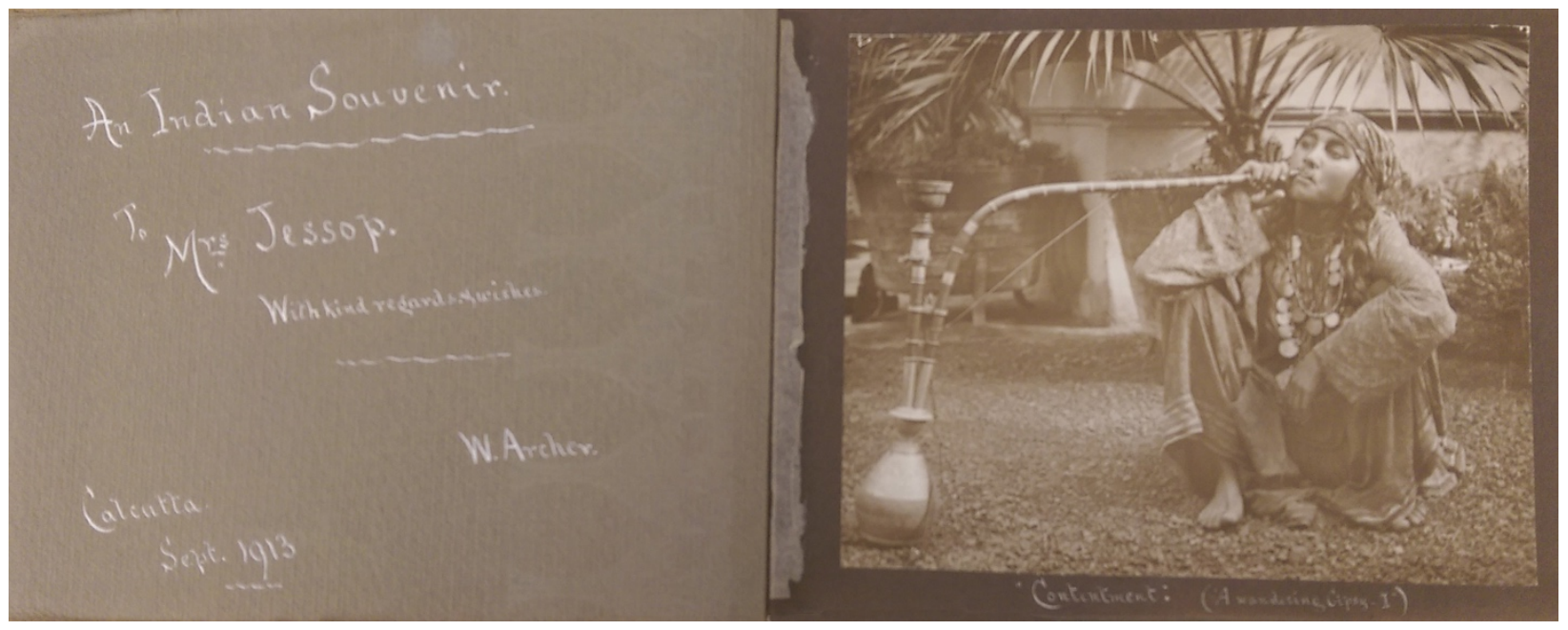

Figure 26. Inside cover and first page from Archer's album, scrapbook collection, Kautz Family YMCA Archives, University of Minnesota. 
Their immorality constituted a part of the religious worship of the temple, polluting priests and people alike, until restrained by the British government.

Defenceless Girls.-Our hearts go out to these poor defeneeless girls in India. Miss Carmichael has begun rescuing little girls who are being sold to the temples for lives of shame. She has over a hundred beautiful, bright-faced children, who had been, or were about to be, sold to the temple and " married to the god "for a life of immorality. For some she paid ten cents, others had been promised to the temple for as high as thirty dollars, while some she got free.

Cruel Alternatives.-There is much that eannot be told. A poor helpless and defenceless widow who is at the merey of the men of her household gives birth to a child. One of three things happens: the mother must go down the well, or the child must be put out of the way by infanticide, or it must be sold to the temple. Miss Carmichael herself tells the story of one of these bright-faced little girls.

Married to the God.- "I was coming home from work a few evenings ago when I met two men and a child. They were easte men in flowing white scarves, dignified, educated men. A sudden fear shot through me, and I looked at the men and they laughed. 'We are taking her to the temple there, to marry her to the god.' The ehild turned once and waved her little hand to me. The men's faces haunted me all that night. And now it is all over, and she is 'tied.' There in the temple sits the holy

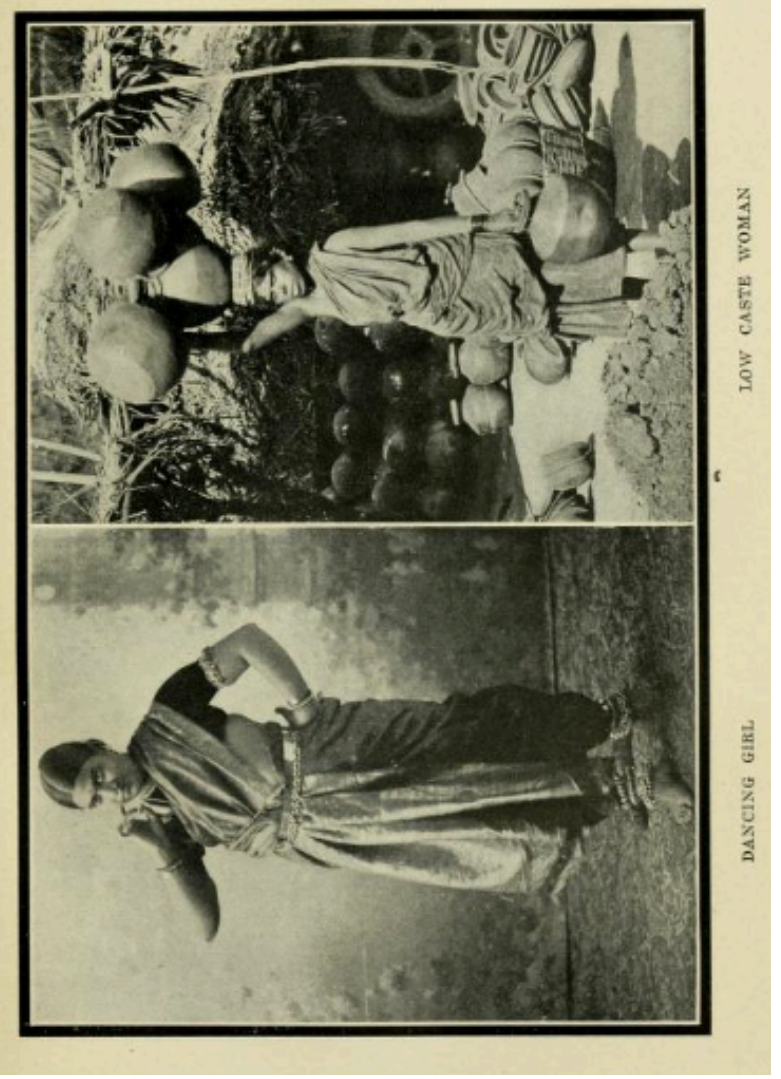

Figure 27. Digital reproduction from India Awakening, pages 152- 153. 


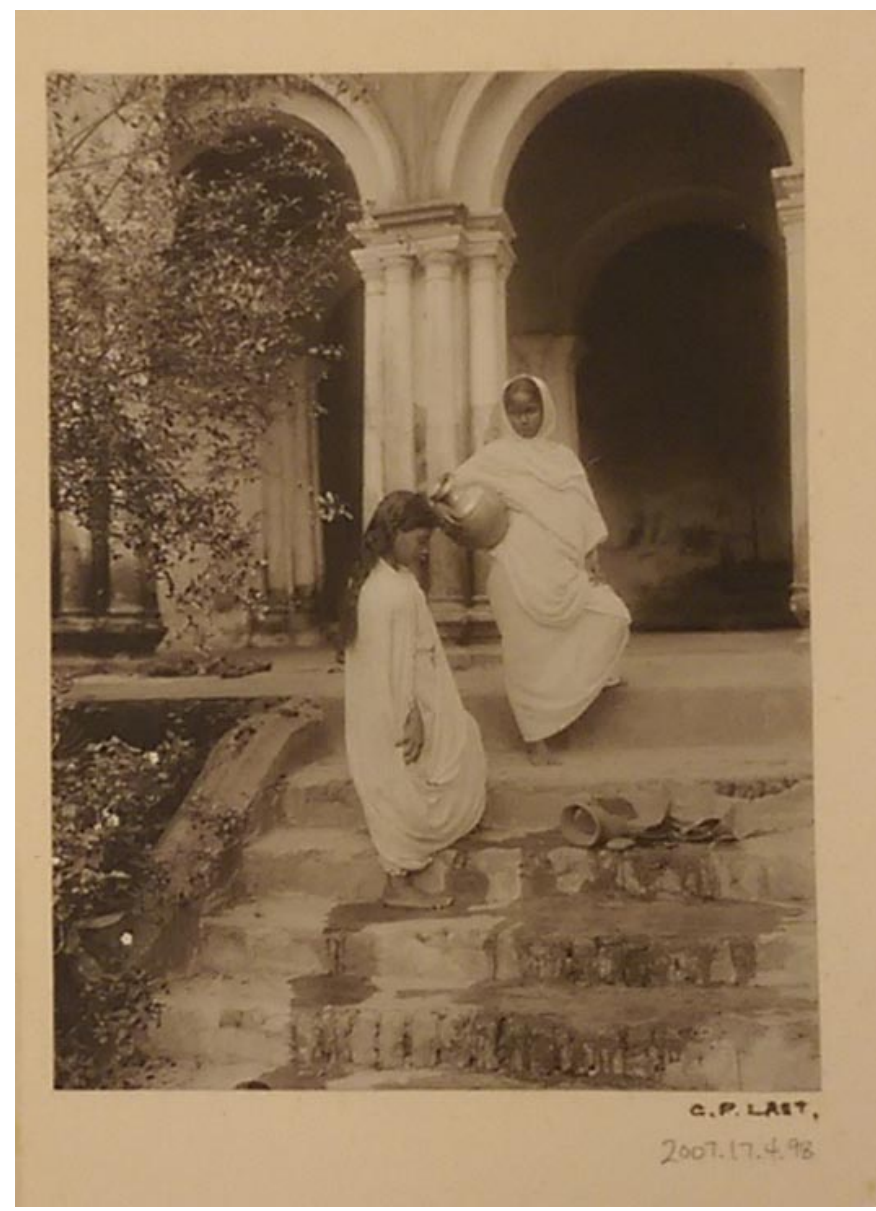

Figure 28. Photograph from page 49 from Brown's album, Royal Ontario Museum collection. 


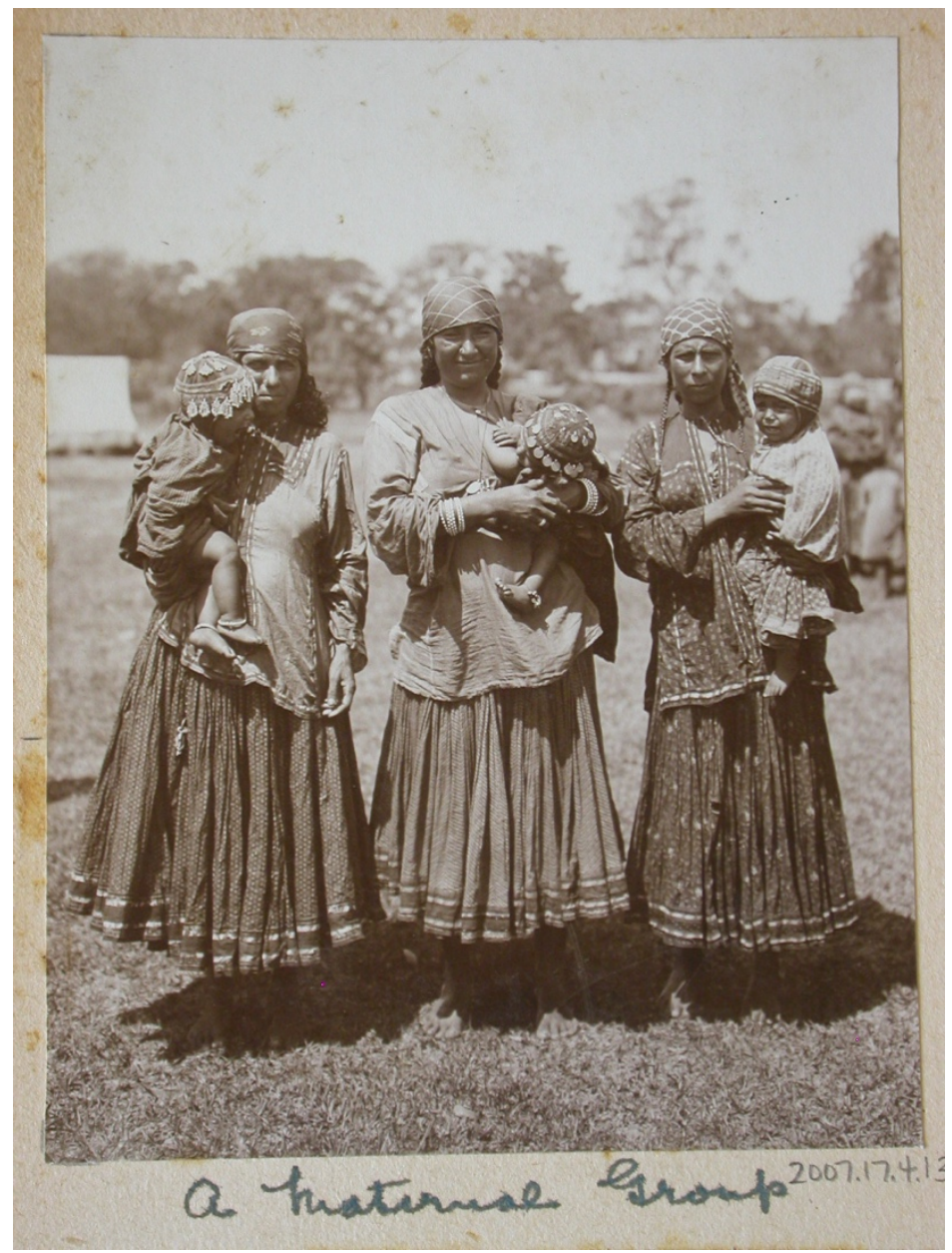

Figure 29. Photograph from loose page associated with Brown's album, Royal Ontario Museum collection. 


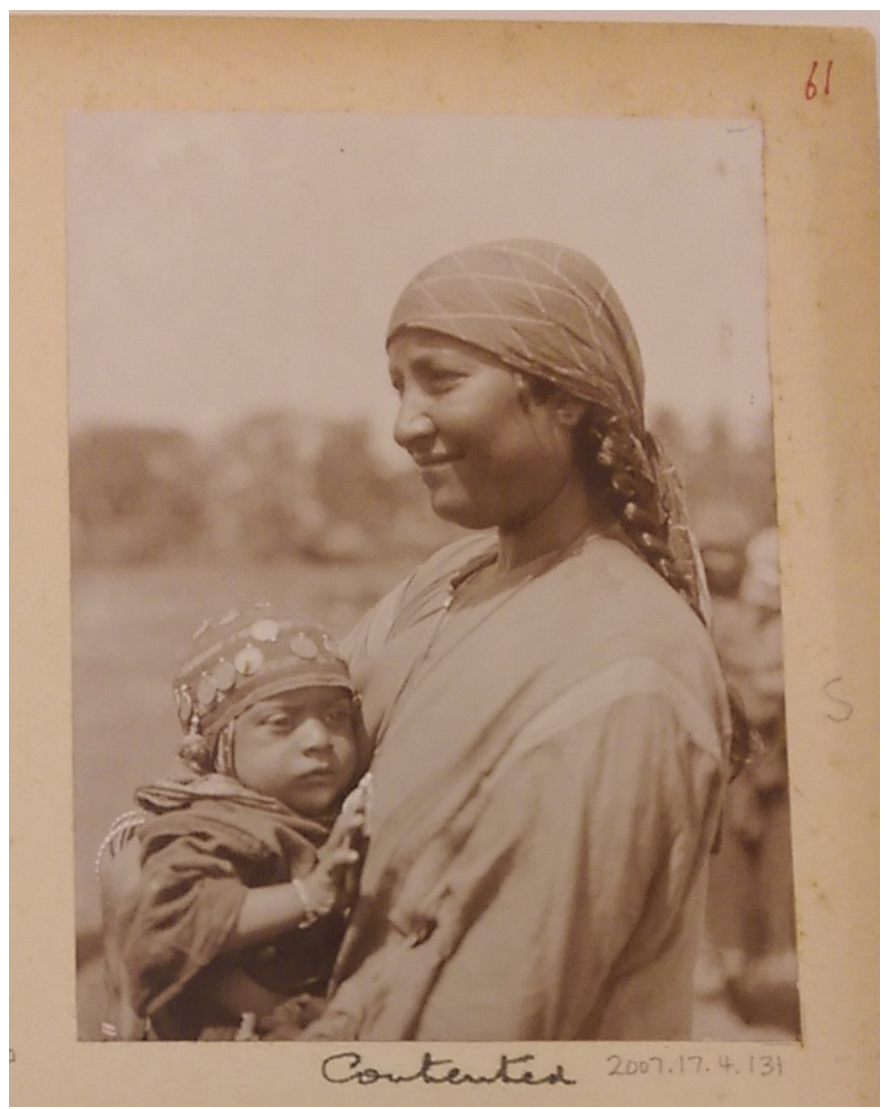

Figure 30. Photograph from loose page associated with Brown's album, Royal Ontario Museum collection. 


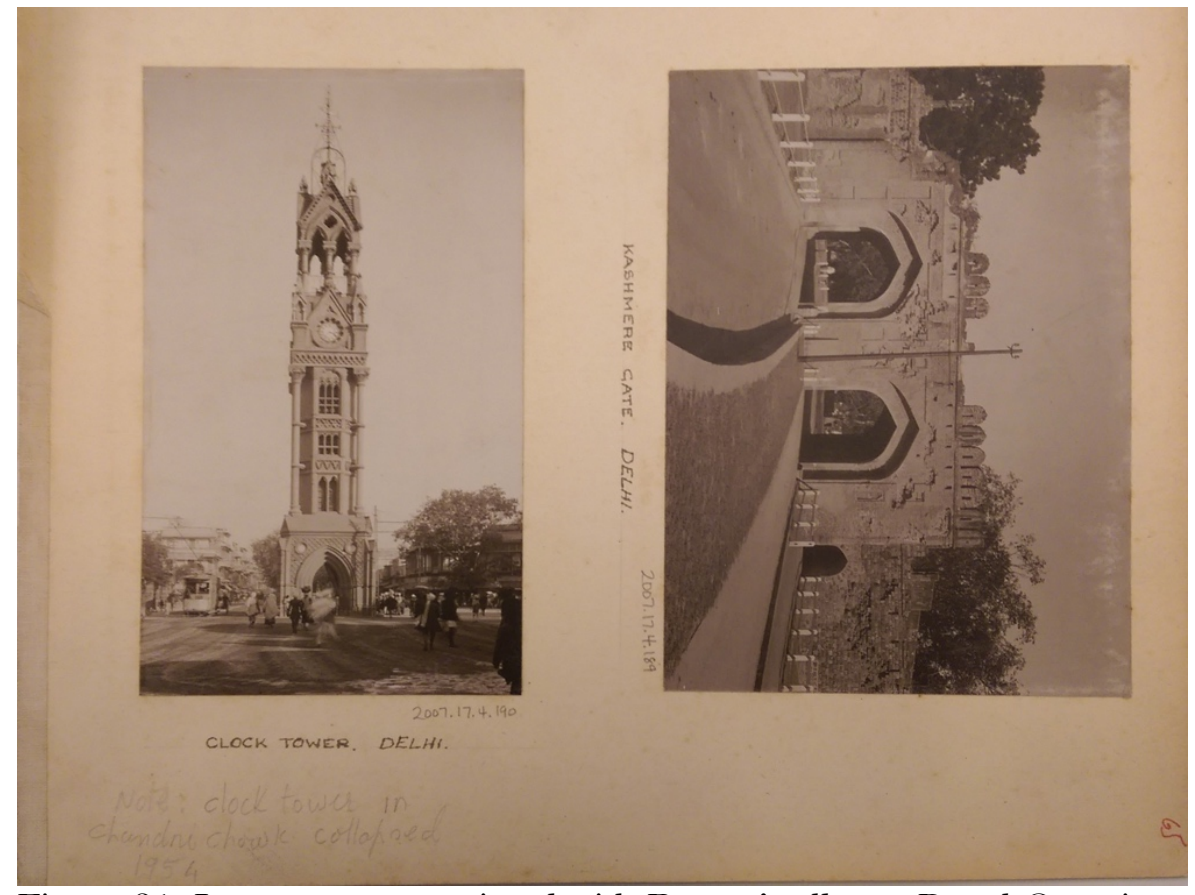

Figure 31. Loose page associated with Brown's album, Royal Ontario Museum collection. 


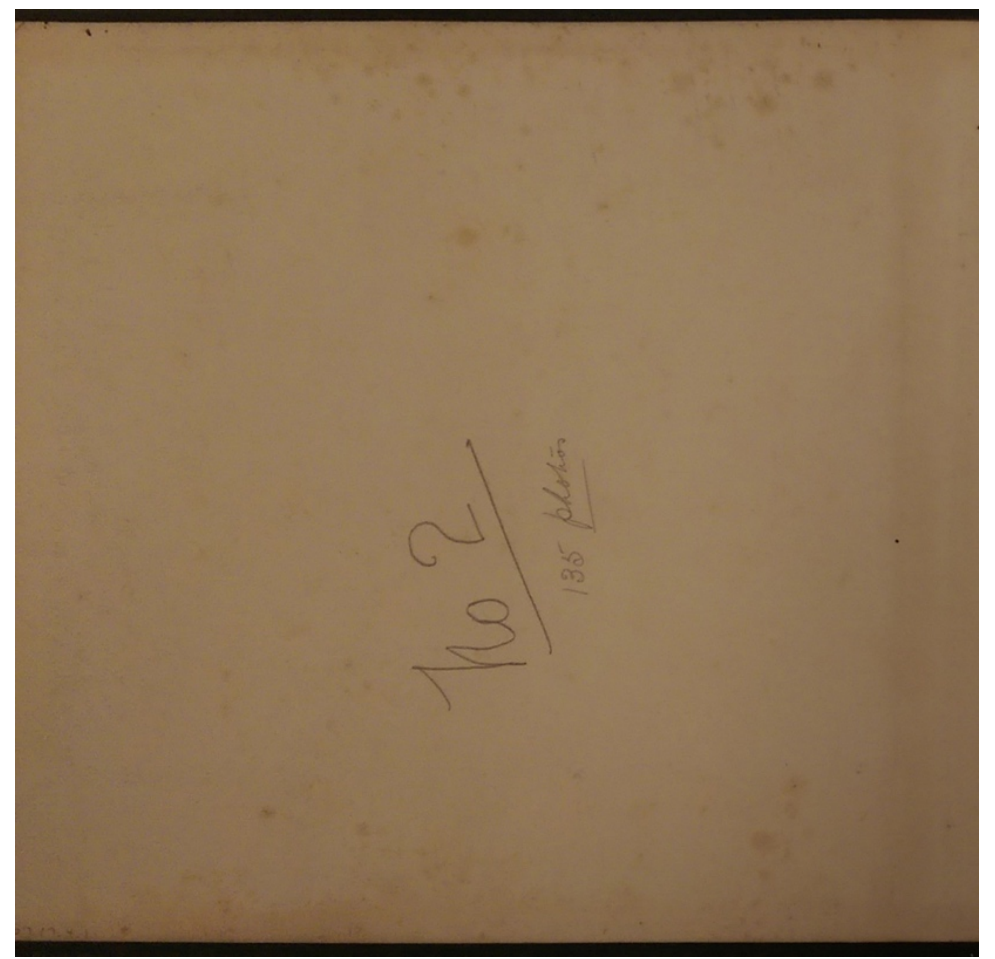

Figure 32. Inside of back cover of Brown's album, Royal Ontario Museum collection. 


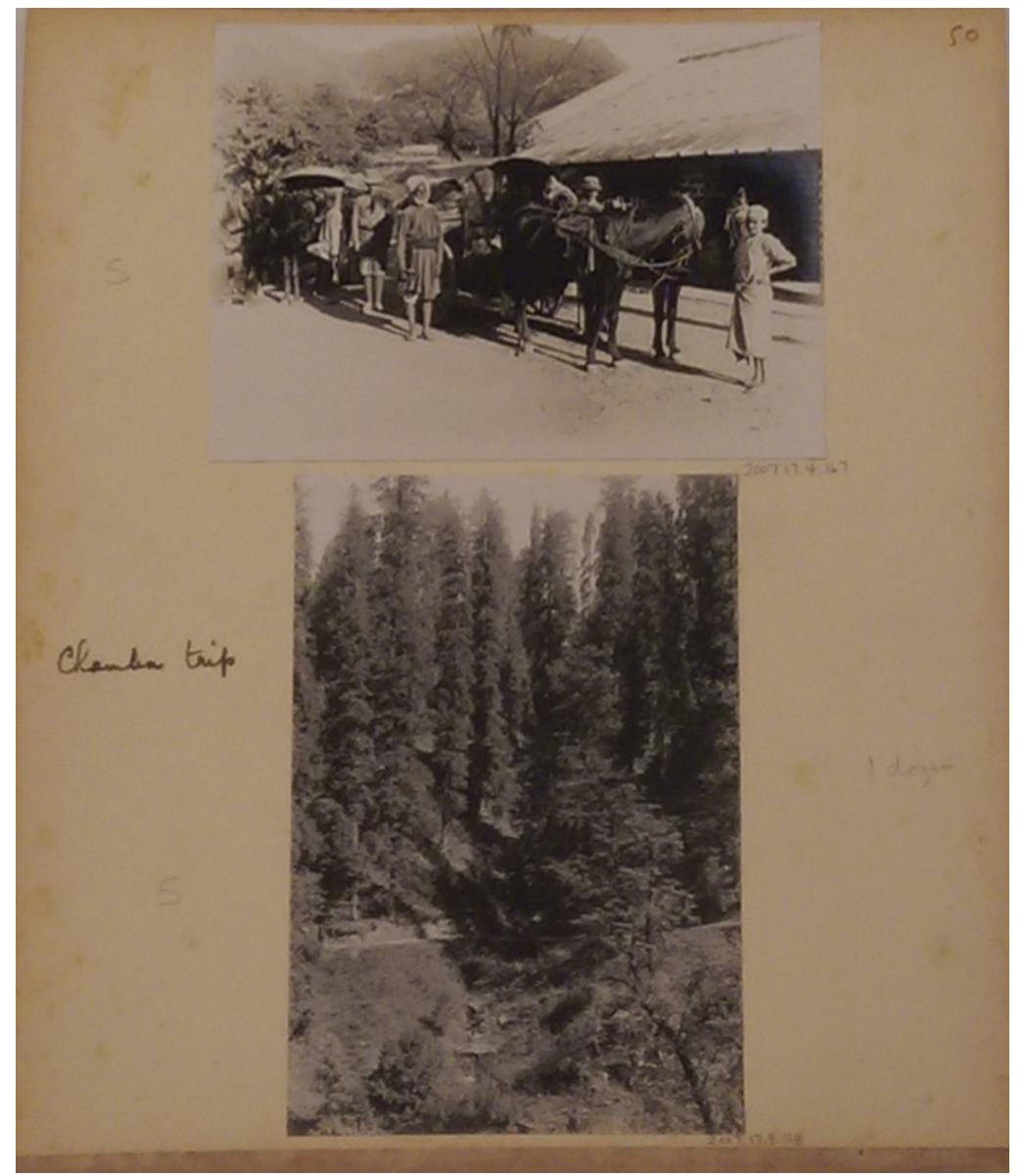

Figure 33. Loose page associated with Brown's album, Royal Ontario Museum collection. 


\section{Bibliography}

Aguilar, Mario L. Christian Ashrams, Hindu Caves and Sacred Rivers: Christian-Hindu Monastic Dialogue in India 1950-1993. London: Jessica Kingsley Publishers, 2016

Aird, Michael."Growing up with Aborigines” in Photography’s Other Histories. Edited by Christopher Pinney and Nicolas Peterson.Durham: Duke University Press, 2003. Pages 5487.

Ari Singh Anand. "Cosmopolitanism in Hobson-Jobson: Remaking Imperial Subjects" in Comparative Studies of South Asia, Africa and the Middle East 31:2 (2011) Pages 521-537.

Arjun Appadurai. The Colonial Backdrop” in Afterimage 24:5 (1997). Page 4+ Academic OneFile

Arnold, David. Colonizing the Body: State Medicine and Epidemic Disease in Nineteenth-century India. Berkeley: University of California Press, 1993.

$==$ Everyday Technology: Machines and the Making of India's Modernity. Chicago: University of Chicago Press, 2013.

---Science, Technology, and Medicine in Colonial India. New York: Cambridge University Press, 2000 .

--- "The medicalization of Poverty in Colonial India” in Historical Research 85:229 (August 2012) pages 448-504.

---"Globalization and Contingent Colonialism: Towards a Transnational history of "British" India" in Journal of Colonialism \& Colonial History 16:2 (July 2015) accessed online http://search.proquest.com.ezproxy.lib.ryerson.ca/docview/1702891302?pqorigsite $=$ summon

Aronson, Amy and Michael S. Kimmel (eds) Men and Masculinities: A Social, Cultural, and Historical Encyclopedia Vol I A-J. Santa Barbara: ABC-CLIO, 2004. Page 477-478.

Atler, Joseph.The Wrestler's Body: Identity, and Ideology in North India. Berkeley: University of California Press, 1992.

---"Indian Clubs and Colonialism: Hindu Masculinity and Muscular Christianity", Comparative Studies in Society and History 46:3 (October 2004) pages 497534.

--- "Somantic nationalism: Indian Wrestling and Militant Hinduism" in Modern Asian Studies 28 (1994) pages 557-588

----YYoga at the Fin de Siecle: Muscular Christianity with a 'Hindu' Twist" in The International Journal of the History of Sport 23:5 (August 2006) pages 759=776. 
Austin, Linda M. "Children of Childhood: Nostalgia and the Romantic Legacy" in Studies in Romanticism 42:1 (Spring 2003) pages 75-98.

Axelby, Richard. "Calcutta Botanic Garden and the Colonial re-ordering of the Indian environment" in Archives of Natural History 35:1 (2008) page 153-156.

Azoulay, Ariella. The Civil Contract of Photography. Trans. Rela Mazali and Ruvik Danieli. New York: Zone Books, 2008.

Bailey, Peter. Leisure and Class in Victorian England: Rational Recreation and the Contest for Control 1880-1885. Toronto and Buffalo: University of Toronto Press, 1978.

Baker, William J. "To Pray or to Play? The YMCA Question in the United Kingdom and the United States, 1850-1900,”in International Journal of the History of Sport 11:1 ( April 1994) pages 42-62.

Banerjee, Sikata and Subho Basu. "The Quest for Manhood: Masculine Hinduism and Nation in Bengal" in Comparative Studies of South Asia, Africa and the Middle East. $26: 3$ ( December 2006) pages 479-490.

Barthes, Roland. Camera Lucida: Reflections on Photography. Trans. Richard Howard. New York: Noonday, Press, 1981.

Basuli Deb. "Cutting across Imperial Feminism toward Transnational Feminist Solidarities" in Meridians: Feminism, Race, Transnationalism 13:2 (2016) page 164 Academic onefile.

Bear, Laura. "Public genealogies: Documents, Bodies and Nations in Anglo-Indian Railway Family Histories” in Contributions to Indian Sociology 35:3 (October 2001) pages 355-388.

Bederman, Gail. Manliness \& Civilization: A Cultural History of Gender and Race in the United States 1880-1917. Chicago: University of Chicago Press, 1995.

Behdad, Ali and Luke Gartlan (eds). Photography's Orientalism: New Essays on Colonial Representation. Los Angeles: Getty Research Institute, 2013.

Behlmer.George K. "The Gypsy Problem in Victorian England” in Victorian Studies 28:2 (January 1985) pages 231-253.

Belton, Brian A. Gypsy and Traveller Ethnicity: The Social Generation of an Ethnic Phenomenon. New York: Routledge, 2004.

Binfield, Clyde. George Williams in Context: A Portrait of the Founder of the YMCA. Sheffield: Sheffield Academic Association in association with YMCA England, 1994.

Blunt, Alison. "Home and Empire: Photographs of British Families in the Lucknow Album, 185657" in Picturing Place: Photography and the Geographical Imagination, edited by Joan M. Schwartz and James R. Ryan. New York; London: I.B Taurus, 2003. Pages 243-260. 
---“Imperial Geographies of Home: British Domesticity in India, 1865-1925” in

Transactions of the Institute of British Geographers 24:4 (December 1999) pages 421-440.

Booth, Douglas. "In-Between the Flags: Reflections on a Narrative of Surf Life Saving Australia" in Rethinking History 12:2 (June 2008) pages 165-187.

Bourdieu, Pierre. Photography: A Middle-Brow Art. Trans. Shaun Whiteside. Stanford: Stanford University Press, 1990.

Boyer, Paul S. Urban Masses and Moral Order in America, 1820-1920. Cambridge: Harvard University Press, 1978.

Brown, Elspeth H. and Thy Phu (eds). Feeling Photography. Durham and London: Duke University Press, 2014.

Buettner, Elizabeth. Empire Families: Britons and Late Imperial India. Oxford; New York: Oxford University Press, 2004.

Bunnell, Peter. "Towards New Photography: Renewals of Pictorialism" in A New History of Photography Edited by Michel Frizot. Köln : Könemann, 1998.

Carnes, Mark C. "Middle-Class men and the Solace of Fraternal Ritual" in Meanings of Manhood: Constructions of Masculinity in Victorian America. Edited by Mark C. Carnes and Clyde Griffin. Chicago: University of Chicago, 1990. Pages 37-66.

Chalfen, Richard. Snapshot Versions of Life. Bowling Green, Ohio. Bowling Green State Univeristy Popular Press, 1987.

Clawson, Mary Anee.Constructing Brotherhood: Class, Gender, and Fraternalism. Princeton: Princeton University Press, 1969.

Close, Susan. "The Camera and the Contact Zone: Re-Envisioning the Representation of Aboriginal Women in the Canadian North” in Transculturation in British Art, 1770-1930. Edited by Julie F. Codell. Surrey and Burlington: Ashgate, 2012. Pages 111-141.

Cohn, Bernard S. Colonialism and Its Forms of Knowledge: The British in India. Princeton: Princeton University Press, 1996.

Collins, Paul M. Christian Inculturation in India. Aldershot, England: Ashgate, 2007.

Coe, Brian and Paul Gates. The Snapshot Photograph: The Rise of the Popular Photograph, 1888-1939. London: Ash \& Grant, 1977.

Constable, Phillip. "Scottish Missionaries, 'Protestant Hinduism' and the Scottish Sense of Empire in Nineteenth and Early Twentieth-Century India” in The Scottish Historical Review 86:2 (December 2007), pages 278-313.

Cope E. Brian, and Michael Kinnamon (ed). The Ecumenical Movement: An Anthology of Key Texts and Voices. Geneva; Grand Rapids: WCC Publications,1997. 
David, M.D. The YMCA and the Making of Modern India: A Centenary History. New Delhi: National Council of YMCAs of India, 1992.

Davidoff, Leonore and Catherine Hall. Family Fortunes: Men and Women of the English Middle Class, 1780-1850. Chicago: University of Chicago Press, 1987.

Deane, Bradley. Masculinity and the New Imperialism: Rewriting Manhood in British Literature, 1870-1914. New York: Cambridge University, 2014.

Dearing, Stewart. "Painting the Other Within: Gypsies according to the Bohemian Artist in the Nineteenth and early Twentieth Centuries" in Romani Studies 20:2 (2010). Pages 161-201.

Dietcher, David. Dear Friends: American Photographs of Men Together. New York: Harry N. Abrams, 2001.

Dussart, Fae Ceridwen.'That Unit of Civilization' and 'the talent peculiar to women': British Employers and their servants in the nineteenth-century in the Indian Empire" in Identities: Global Studies in Culture and Power 22:6 (2015) pages 706-721.

Eddy, Sherwood. India Awakening. New York: Missionary Education Movement of the United States and Canada, 1911.

Edwards, Elizabeth and Janice Hart (eds). Photographs Objects Histories: On the Materiality of Images. London; New York: Routledge, 2004.

Elizabeth Edwards (ed). Photography and Anthropology: 1860-1920. New Haven and London: Yale University Press and The Royal Anthropological Institute London, 1992.

--- "Negotiating Spaces: Some Photographic Incidents in the Western Pacific, 1883-84" in Picturing Place: Photography and the Geographical Imagination, edited by Joan M. Schwartz and James R.Ryan. New York; London: I.B Taurus, 2003. Pages 261-280.

Eisler, Colin. “Going Straight: Camera Work as Men’s Work in the Gendering of American Photography, 1900-1923” in Genders 30 ) 1999 accessed online at https://www.atria.nl/ezines/IAV_606661/IAV_606661_2010_51/g30_eisler.txt

Flood, Gavin.An Introduction to Hinduism. Cambridge: Cambridge University Press, 1996.

Fretheim, Kjetil. "Whose Kingdom? Which Context? Ecumenical and Contextual Theology in the World Alliance of YMCAs” in International Review of Mission 97: 384-385 (January 2008) pages 116-128.

Furr, Derek. "The Perfect Match: Wordsworth's 'The Triad' and Coleridge's 'The Garden of Bocccacio” in Romantic Texualities: Literature and Print Culture, 1780-1840 ( Winter 2005) pages 49- 68. 
Garnham, Neal. "Both Praying and Playing: 'Muscular Christianity' and the YMCA in North-East County Durham” in the Journal of Social History 35:2 (December 2001) pages 397-407.

Gartlan, Luke. "Dandies on the Pyramids: Photography and German-Speaking Artists in Cairo" in Photography's Orientalism: New Essays on Colonial Representation. Edited by Ali Behdad and Luke Gartlan. Los Angeles: Getty Research Institute, 2013. Pages 129-152.

Gautrand, Jean Claude. "Photography on the Spur of the Moment" in A New History of Photography Edited by Michel Frizot.Köln: Könemann,1998.

Gustavson, Todd. Camera: A History of Photography from Daguerreotype to Digital. New York: Sterling Innovation, 2009.

Gustav-Wrathall. John Donald.Take the Young Stranger by the Hand: Same-sex Relations and the YMCA. Chicago: University of Chicago Press, 1998.

Hall, Donald E.(ed). Muscular Christianity: Embodying the Victorian Age. Cambridge; New York: Cambridge University Press, 1994.

Harald Fisher-Tiné. "Reclaiming Savages in 'Darkest England' and 'Darkest India': The Salvation Army as Transnational agent of the Civilizing Mission' in Civilizing Missions in Colonial and Postcolonial South Asia. Edited by Carey A. Watt and Michael Mann. London: Anthem Press, 2011.Pages 125-165.

--- "Fitness for Modernity?-The American YMCA and Physical Education Schemes in L ate-Colonial South Asia (c.1890-1940)" forthcoming publication in Modern Asian Studies.

---“The Making of a 'Ruling Race': Defining and Defending Whiteness in Colonial India” In Racism in the Modern world: Historical Perspectives on Cultural Transfer and Adaptation. Edited by Manfred Berg \& Simon Wendt.New York: Berghahn Books, 2011. Pages 213-235.

Hardgrave, Robert L. Jr. "The Breast-Cloth Controvery: Caste Consciousness and Social Change in Southern Travancore” in The Indian Economic \& Social History Review 5:2 (1968) pages 171-187.

Harker. Margaret. The Linked Ring: The Secession Movement in Photography in Britain, 18921910. London: Heinemann Ltd, 1979.

Harland-Jacobs, Jessica L. Builders of Empire: Freemasons and Imperialism, 1717-1927. Chapel Hill: University of North Carolina, 2013.

Harper- Billington, Susan. In the Shadow of the Mahatma: Bishop V.S Azariah and the Travails of Christianity in British India. Grand Rapids, Michigan: W.B Eerdmans Publishing, 2000.

Hasian Jr, Marouf Arif. The Rhetoric of Eugenics in Anglo-American Thought. Athens: University of Georgia Press, 1996. 
Hill, Frederick H. "When I knew Minor White” in History of Photography 16:2 (1992) pages 147151.

Hirsch, Julia. Family Photographs: Content, Meaning, and Effect. New York: Oxford University Press, 1981.

Hirsch, Marianne and Leo Spitzer. "School Photos and Their Afterlives" in Feeling Photography. Edited by Elspeth H. Brown and Thy Phu. Durham: Duke University Press, 2014.

Hirsch, Marianne (ed). The Familial Gaze. Hanover, New Hampshire: Dartmouth College, 1999.

----Family Frames: Photography, Narrative, and Postmemory. Cambridge: Harvard University, 1997.

Hopkins, Charles Howard. History of the Y.M.C.A in North America. New York: Association Press, 1951.

Hubner, Stefan. "Muscular Christianity and the Western Civilizing Mission: Elwood S.Brown, the YMCA and the Idea of the Far Eastern Championship Games,” Diplomatic History 39:3 (June 2015) pages 532-557.

Inderpal Grewal. Home and the Harem: Nation, Gender, Empire and the Cultures of Travel. Durham and London: Duke University Press, 1996.

Ingham, Kenneth. "The English Evangelicals and the Pilgrim Tax" in The Journal of the Royal Asiatic Society 85:1-2 (1953) pages 13-22.

Janes, Dominic Victorian Reformation: The Fight Over Idolatry in the Church of England, 18401860. Oxford: Oxford University Press, 2009.

Jay, Martin and Sumathi Ramaswamy. Empires of Vision: A Reader. Durham: Duke University Press, 2014.

Johnson, Elmer L. The History of the YMCA Physical Education. Chicago: Association Press, 1979.

Karlekar, Malavika. Re-visioning the past: Early Photography in Bengal, 1875-1915. New Delhi, Oxford University Press,2005.

Kaviraj, Sudipta. "Filth and the Public Sphere Concepts and Practices about Space in Calcutta" in Public Culture 10:1 (1997) pages 83-113.

Kazal. Andrew Russell. Becoming Old Stock: The Paradox of German-American Identity. Princeton: Princeton University Press, 2004.

Kennedy, Dane. Magic Mountains: Hill Stations and the British Raj. Berkeley: University of California Press, 1996. 
Kent, Eliza. Converting Women: Gender and Protestant Christianity in Colonial South India. Oxford: Oxford University Press, 2004.

Kimmel, Michael S. "Consuming Manhood: The Feminization of American Culture and the Recreation of the American Male Body, 1832-1920" in The History of Men: Essays in the History of American and British Masculinities. Edited by Michael S. Kimmel. New York: State University of New York, 2005. Pages 37-60.

Kotchemidova, Christina. "Why We Say 'Cheese': Producing the Smile in Snapshot Photography" in Critical Studies in Media Communication 22:1 (2005) pages 2-25.

Laderman, Scott. Empire in Waves: A Political History of Surfing. Berkeley: University of California Press, 2014.

Langford, Martha. Suspended Conversations: The Afterlife of Memory of Photographic Albums. Montreal: McGill-Queens University Press, 2001.

Latourette, Kenneth Scott. World Service: A History of the Foreign Work and World Service of the Young Men's Christian Association of the United States and Canada. New York: Association Press, 1957.

Leong-Salobir, Cecilia. Food Culture in Colonial Asia: A Taste of Empire. London: Routledge, 2011. Page 57.

Lord, Alexandra M. "Models of Masculinity: Sex Education, the United States Public Health Service and the YMCA, 1919-1924" in Journal of the History of Medicine and Allied Sciences 58:2 (2003) pages 123-152.

Love, Christopher. "Swimming and Gender in the Victorian World" in The International Journal of the History of Sport.24:5 (2007) pages 586-602.

Lupkin, Paula. Manhood Factories: YMCA Architecture and the Making of Modern Urban Culture. Minneapolis: University of Minnesota Press, 2010.

Macleod, David M. Building Character in the American Boy: The Boy Scouts, YMCA and Their Forerunners, 1870-1920. Madison: University of Wisconsin Press, 1983.

Mahadevan, Sudhir. A Very Old Machine: the Very Origins of Cinema in India. Buffalo: State University of New York, 2015.

Mallampalli, Chandra. Christians and Public Life in Colonial South India, 1863-1937: Contending with Marginality. London; New York: Routledge Curzon, 2004.

Martens, James W. "Young Man! When you're low on your Dough: the Depression and YMCA's Leisure Time League" in Alberta History 52:4 (September 2004) pages 22-26.

Mayall, David. Gypsy-Travellers in Nineteenth-Century Society. Cambridge: Cambridge University Press, 1988. 
McClelland, Dalton F. World Revolution: The College Student and the YMCA. New York:

International Committee of the YMCA's of the United States and Canada, 1959.

McClintock, Anne. Imperial Leather: Race, Gender and Colonial Conquest. New York: Routledge, 1995.

Milne-Smith, Amy. London Clubland: A Cultural History of Gender and Class in Late-Victorian England. New York: Palgrave Macmillan, 2011.

Mjagkij, Nina and Margaret Spratt (eds). Men and Women Adrift: The YMCA and the YWCA in the City. New York: New York University Press, 1997.

Mjagkij, Nina. Light in the Darkness: African Americans and the YMCA, 1852-1946. Kentucky: University of Kentucky, 2003.

Mitter, Partha et al. The Artful Pose: Early Studio Photography in Mumbai c.1855-1940. Ahmedabad, Gujarat: Mapin Publishing; Ocean Township, New Jersey, 2010.

Mizutani, Satoshi. The Meaning of White: Race, Class, and the 'Domiciled Community' in British India 1858-1930. Oxford: Oxford University Press, 2011.

Morgan, David. The Sacred Gaze: Religious Visual Culture in Theory and Practice. Berkeley: University of California, 2005.

Mohanram, Radhika. Imperial White: Race, Diaspora, and the British Empire. Minneapolis: University of Minnesota Press, 2007.

Moloney, Deidre M. National Insecurities: Immigrants and U.S. Deportation Policy Since 1882. Chapel Hill: University of North Carolina, 2012.

Murray, Sharon."From Album to Archive: Context, Meaning and Two Photographic Albums from an India Mission” published in Archivaria (2008).

--- "Missionizing Photograph: Miss Amanda Jefferson’s Photograph album, 1892-1898”. Master of Arts Thesis. Concordia University, 2007.

Nagle, Traci. “The Visible and Invisible Influence of Yule's Hobson-Jobson on Murray's Oxford English Dictionary” in International Journal of Lexicography 27:3 (August 2014) pages 280-308.

Nair, V. Sankaran. Swadeshi Movement: The Beginnings of Student Unrest in South India. Delhi: Mittal Publications, 1985.

Nauright, John and S.W. Pope. Routledge International Handbooks: Routledge Companion to Sports History. New York: Routledge, 2010. 
Neill, Stephen Charles and Ruth Rouse. A History of the Ecumenical Movement, 1517-1948. Philadelphia: Westminster Press, 1954.

Nelslon, Dana D. National Manhood; Capitalist Citizenship and the Imagined Fraternity of White Men. Durham and London: Duke University Press, 1998.

Newton, Judith. From Panthers to Promise Keepers: Rethinking the Men's Movement. Lanham, Maryland: Rowman \& Littlefield Publishers, 2005.

Nochlin, Linda. "Morisot's Wet Nurse: The Construction of Work and Leisure in Impressionist Painting" in The Expanding Discourse: Feminism and Art History. Edited by Norma Broude and Mary D. Garrad. Pages 231-244.

Nord, Deborah Epstein. Gypsies \& the British Imagination, 1807-1930. New York: Columbia University Press, 2006.

Osterman, Mark “The Technical Evolution of Photography in the $19^{\text {th }}$ century" in Focal Encyclopedia of Photography: Digital Imaging, Theory and Applications, History and Science. Edited by Michael R. Peres. Amsterdam and Boston: Elsevier/ Focal Press, 2007. Pages 23-36.

Page, JudithW. Wordsworth and the Cultivation of Women. Berkeley: University of California Press, 1994.

Parr, Susie. The Story of Swimming: A Social History of Bathing in Britain. Stockport: Dewi Lewis Media, 2011.

Pasternak, Gil. "Intimate Conflicts: Foregrounding the Radical Politics of Family Photographs" in Photography, History, Difference, edited by Tanya Sheehan. Hanover; New Hampshire: Dartmouth College Press, 2015. Pages 217-240.

Pauly. Philip J. "The World and All That is in It: The National Geographic Society, 1888-1918” in American Quarterly 31:4 (1979) pages 517-532.

Pennington, Brian K. Was Hinduism Invented: Britons, Indians, and the Colonial Construction of Religion. New York: Oxford University Press, 2005.

Peterson, Nicolas and Christopher Pinney (ed). Photography's Other Histories. Durham: Duke University Press, 2003.

Peterson, Christine A. After the Photo-Secession: American Pictorial Photography, 1910-1955. Minneapolis: The Minneapolis Institute of Arts, 1997.

Pheonix, Karen. "A Social Gospel for India" in The Journal of the Gilded Age and Progressive Era 13:2 (April 2014) pages 200-222.

Pickens, Donald K. Eugenics and the Progressives. Nashville, Vanderbilt University Press, 1968. 
Pinney, Christopher. Camera Indica: The Social Life of Indian Photographs. London: Reaktion Books, 1997

---"Civil Contract of Photography in India” in Comparative Studies of South Asia, Africa, and the Middle East 35:1 (2015) pages 21-34.

---"Classification and Fantasy in the Photographic Construction of Caste and Tribe" in Visual Anthropology 3 (1990) pages 259-288.

--- Photography and Anthropology. London: Reaktion Books, 2011.

---The Coming of Photography in India. London: The British Library, 2008.

--- "What's Photography got to do with it?" in Photography's Orientalism: New Essays on Colonial Representation, edited by Ali Behdad and Luke Gartlan. Los Angeles: Getty Research Institute, 2013. Pages 33-52.

Pivar, David "The Military, Prostitution, and Colonial Peoples; India and the Philippines, 18851917” in The Journal of Sex Research 17:3 (1981) pages 256- 269.

Pollack, Griselda. "The Grace of Time: Narrativity, Sexuality, and a Visual Encounter in the Virtual Feminist Museum” in Art History 26:2 (April 2003) pages 174-213.

Pratt, Mary Louise. Imperial Eyes: Travel Writing and Transculturation. New York: Routledge, 1992.

Proctor, Tammy M. "Scouts, Guides, and the Fashioning of Empire," 1919-39 in Fashioning the Body Politic: Dress, Gender, Citizenship. Edited by Wendy Parkins. Oxford; New York: Berg Publishers, 2002. Pages 125-144.

Purcell, Susan. "The Law of Hobson-Jobson” in English Today 25:1 (March 2009). Pages 60-64.

Putney, Clifford. Muscular Christianity: Manhood and Sports in Protestant America, 1880-1920. Cambridge, Massachusetts: Harvard University Press, 2001.

---"Luther Gulick: His Contributions to Springfield College, the YMCA, and "Muscular Christianity” in Historical Journal of Massachusetts 39:1/2 (July 2011) pages 1-26.

Ralston, Helen. Christian Ashrams: A New Religious Movement in Contemporary India. Lewiston NY and Queesnston, ON: Edwin Mellon Press, 1987.

Ramsland, John. "They ride the surf like gods: Sydney-side Beach Culture, Life-saving and Eugenics 1902-1940" in A Race for Place, edited by Martin Crotty, John Germov, and Grant Rodwell. New Castle: University of New Castle, 2000.

Reznick, Jeffrey S.Healing the Nation: Soldiers and the Culture of Caregiving in Britain During the Great War. Manchester: Manchester University Press, 2004. 
Robert, Dana L. "The Origin of the Student Volunteer Watchword: 'The Evangelization of the World in This Generation.” In International Bulletin of Missionary Research (1968) pages $146=149$.

Romantic Circles. "Introduction to The Keepsake" Romantic Circles accessed at https://www.rc.umd.edu/editions/lel/ksintro.htm\#1

Rose, Gillian. Doing Family Photography: The Domestic, the Public and the Politics of Sentiment. Farnham, England and Burlington, Vermont: Ashgate Publishing, 2010.

Rosen, Christine. Preaching Eugenics: Religious Leaders and the American Eugenic Movement.Oxford: Oxford University Press, 2004.

Rosenberg, Emily S. Spreading the American Dream: 1890-1945. New York: Wang and Hill, 1982.

Rotundo, Anthony. American Manhood: Transformations in Masculinity from the Revolution to the Modern era. New York: BasicBooks,1993.

Ryan, James R. Picturing Empire: Photography and the Visualization of the British Empire. Chicago: University of Chicago, 1998.

Ryan, Mary. Cradle of the Middle Class: The Family in Oneida County, New York, 1790-1865. New York: Cambridge University Press, 1981.

Sailor, Rachel “'You Must Be Dreamy': Complicating Japanese-American Pictorialism and the Early Twentieth-Century Regional West” in European Journal of American Studies 9:3 (2014) accessed online http://ejas.revues.org/10405

Seiberling, Grace, Carolyn Bloore and George Eastman House. Amateurs, Photography, and the Mid-Victorian Imagination. Chicago: University of Chicago,1986.

Sen, Indrani. "Colonial Domesticities, Contentious Interactions: Ayahs, Wet-nurses and Memsahibs in Colonial India: in Indian Journal of Gender Studies 16:3 (September 2009) page 323-325

Sengupta, Debjani. "Zenana Studio: Early Women Photographers of Bengal, from Taking Pictures: The Practice of Photography by Bengalis, by Siddhartha Ghosh" in Trans Asia Photography Review 4:2 (Spring 2014) online http://hdl.handle.net/2027/spo.7977573.0004.202

Sharpe, Eric J. Not to Destroy but to Fulfill: The Contribution of J.N Farquhar to Protestant Missionary Thought in India before 1914. Lund: C.W.K Gleerup, 1965.

Shedd, Clarence P. History of the World's Alliance of the Young Men's Christian Associations. London: S.PC.K., 1955. Page 133. 
Sinha, Mrinalini. Colonial Masculinity: the 'Manly Englishman' and the 'Effeminate Bengali'in the late Nineteenth Century. Manchester; New York: Manchester University Press; New York: St. Martin's Press, 1995.

--- "Britishness, Clubbality, and the Colonial Public Sphere" in Bodies in Contact:

Rethinking Colonial Encounters in World History. Edited by Antionnette Burton and

Tony Ballantyne. Durham and London: Duke University Press, 2005. Pages 183-201

Singh.Maina Chawla. Gender, Religion, and "Heathen Lands." American Missionary Women in South Asia (1860s-1940s). New York and London: Garland Publishing Inc, 2000

Singleton, Mark. Yoga Body: The Origins of the Modern Posture Practice. Oxford: Oxford University Press, 2010.

Smith., Shawn Michelle American Archives: Gender, Race, and Class in Visual Culture. Princeton: Princeton University Press, 1999.

Snow, Jennifer C. Protestant Missionaries, Asian Immigrants, and Ideologies of Race in America, 1850-1924. New York: Routledge, 2007.

Sontag, Susan. On Photography. London: Allen Lane, Penguin Books, 1978.

Spence, Jo and Patricia Holland (eds). Family Snaps: The Meaning of Domestic Photography. London: Virago, 1991.

Spurr, Geoffrey D. "The London YMCA: A Haven of Masculine Self-Improvement and Socialization for the Late-Victorian and Edwardian Clerk" in the Canadian Journal of History 37:2 (August 2002) page 290-301.

Stanley, Brian. The World Missionary Conference, Edinburgh 1910. Grand Rapids: William B.Eerdmans Publishing, 2009.

Strassler, Karen. Refracted Visions: Popular Photography and National Modernity in Java. Durham: Duke University Press, 2010.

Stoler, Anne Laura.Carnal Knowledge and Imperial Power: Race and the Intimate in Colonial Rule. Berkeley: University of California Press, 2010.

Subhakanta, Behera. "Essentialising the Jagannath cult: a discourse on self and other" in Journal of Comparative Literature \& Aesthetics 30:1-2 (Annual 2007) pages 51-93.

Suleri, Sara. The Rhetoric of English India. Chicago: University of Chicago Press, 1992. Chicago: University of Chicago Press, 1992.

Tarlo, Emma. Clothing Matters: Dress and Identity in India. Chicago: University of Chicago, 1996.

Tosh, John. A Man's Place: Masculinity and the Middle-Class Home in Victorian England. New Haven: Yale University Press, 1998. 
---"Home and Away: The Flight from Domesticity in Late-Nineteenth Century in England Re-visited” in Gender \& History 27:3 (November 2015) pages 561-575.

Trumpener, Katie. "The Time of the Gypsies: A "People without History" in the Narratives of the West” in Critical Inquiry 18 (Summer 1992) pages 843-84.

Turbin,Carole. "Fashioning the American Man: The Arrow Collar Man, 1907-1931" in Gender \& History 14:3 (November 2002) pages 470-491.

Tyrrell, Ian. Reforming the World: The Creation of America's Moral Empire. Princeton: Princeton University Press, 2010.

Untracht, Oppi. Traditional Jewelry of India. New York: Harry N. Abrams Inc, 1997.

Vance, Norman. The Sinews of the Spirit: The Ideal of Christian Manliness in Victorian Literature and Religious Thought. Cambridge; New York: Cambridge University Press, 1985.

Walkovitz, Judith R. "The Indian Woman: the Flower Girl, and the Jew: Photojournalism in Edwardian London” in Victorian Studies 42:1 (Autumn 1998-Autumn 1999) pages 3-46.

Warren, Andrew and Chris Gibson. Surfing Places, Surfboard makers: craft, creativity, and Cultural Heritage in Hawai'i, California, and Australia. Honolulu: University of Hawai'I Press, 2014.

Watney, Simon. "On the Institutions of Photography" in Photography/ Politics Two. London: Photography Workshop, 1979. Pages 187-197.

West, Nancy Martha. Kodak and the Lens of Nostalgia. Charlottesville: University of Virginia Press, 2000.

Westerkamp, Marilyn J. "Female Leadership roles in American Awakenings, 1730-1830" in The Rise of the Laity in Evangelical Protestantism. Edited by Deryck Lovegrove. London: Routledge,2003. Pages 95-115.

Wexler, Laura. Tender Violence: Domestic Visions in an Age of U.S. Imperialism. Chapel Hill and London: University of North Carolina Press, 2000.

White, Cameron. "Save us from the Womanly Man: The transformation of the Body on the Beach in Sydney" in Men and Masculinities 10:1 (2007) pages 22-38.

White, Gleeson.” The Nude in Photography” in A Photographic Vision: Pictorial Photography, 1889-1923 Edited by Peter C. Bunnell. Salt Lake City: Peregrine Smith Inc,1980. Pages $78-84$.

Winter, Thomas. Making Men, Making Class: The YMCA and Workingmen, 1877-1920.

Chicago: University of Chicago Press, 2002. 
Wordsworth, William. The Complete Poetical Works. London: Macmillan and Co., 1888; Bartleby.com 1999. www.bartleby.com/145/

--- The Complete Poetical Works. London: Macmillan and Co., 1888; Bartleby.com, 1999. accessed online at http://www.bartleby.com/145/ww124.html

Zald, Mayer N. Organizational Change: The Political Economy of the YMCA. Chicago: University of Chicago Press, 1970. 